\title{
RESISTENCIA DE CLONES DE LARANJEIRA 'PÊRA' E VARIEDADES AFINS À MANCHA PRETA DOS CITROS
}

\author{
Evandro Henrique Schinor
}

Engenheiro Agrônomo

Orientador: Prof. Dr. FRANCISCO dE ASSIS ALVES MOURÃO FILHO

Dissertação apresentada à Escola Superior de Agricultura "Luiz de Queiroz", Universidade de São Paulo, para obtenção do título de Mestre em Agronomia, Área de Concentração: Fitotecnia.

P I R A C I C A B A

Estado de São Paulo - Brasil

Agosto - 2001 
Dados Internacionais de Catalogação na Publicação (CIP) DIVISĀO DE BIBLIOTECA E DOCUMENTAÇĀO - Campus "LuIZZ de QueirOz"/USP

Schinor, Evandro Henrique

Resistência de clones de laranjeira 'Pêra' e variedades afins à mancha preta dos citros / Evandro Henrique Schinor. - - Piracicaba, 2001.

$90 \mathrm{p}$.

Dissertação (mestrado) - - Escola Superior de Agricultura Luiz de Queiroz, 2001. Bibliografia.

1. Ascomiceto 2. Clone 3. Fungo 4. Laranja pêra 5. Mancha-preta-dos-citros 6. Relaçāo planta-patógeno 7. Resistência à doença 8. Variedade I. Titulo

CDD 634.31 


\section{DEDICATÓRIA}

Aos meus pais Vivaldo e Maria Inês,

à minha irmã Elisandra, e à Simone

Bueno de Camargo

Dedico 


\section{AGRADECIMENTOS}

Aos meus pais Vivaldo José Schinor e Maria Inês Bellon Schinor pela educação, pela formação, pelo apoio e pela força dada nos momentos mais dificeis de minha vida.

À minha irmã Elisandra Cristina Schinor pela amizade, companheirismo e pelo constante apoio.

À Simone Bueno de Camargo pelo amor, companheirismo e compreensão.

Ao Prof. Dr. Francisco de Assis Alves Mourão Filho pela orientação deste trabalho, pela amizade e pelos conselhos dados.

Ao pesquisador e amigo Carlos Ivan Aguilar-Vildoso pela fundamental colaboração como co-orientador deste trabalho, pela amizade e pelos conselhos dados.

Ao Dr. Joaquim Teófilo Sobrinho por ter cedido a área experimental para o desenvolvimento deste trabalho.

À Graziele Ramos Sasseron, estudante de Biologia, pela amizade, dedicação e pela ajuda na coleta de dados de campo e de laboratório.

Aos estudantes de Biologia Tiago Henrique Degasperi e Angelo Renato Féola, pela amizade e ajuda na coleta de dados de campo.

À Fabiana Alencar, técnica da Clínica Fitopatológica de Citros do Centro de Citricultura 'Sylvio Moreira', pela amizade e colaboração. 
À Valéria, técnica do Laboratório de Qualidade do Centro de Citricultura 'Sylvio Moreira', pela ajuda nas análises de qualidade de suco.

A todos os estagiários da Clínica Fitopatológica de Citros do Centro de Citricultura 'Sylvio Moreira' pela amizade e incentivo.

Aos colegas do Curso de Pós-Graduação em Fitotecnia da ESALQ, em especial à Taysa Fonseca pela amizade e incentivo a este trabalho.

Ao Prof. Dr. Ricardo Oliveira e ao Departamento de Ciências Biológicas da ESALQ, pelo empréstimo do Quantômetro para realização do experimento de mensuração da luminosidade no interior das plantas.

Ao Centro de Citricultura 'Sylvio Moreira' - IAC pelo uso de suas dependências para o desenvolvimento deste trabalho.

Ao Fundecitrus pelo apoio financeiro a este trabalho.

À FAPESP pelo apoio financeiro a este trabalho e pela bolsa de mestrado concedida.

E a todas as pessoas que de uma maneira ou de outra colaboraram para a realização deste trabalho. 


\section{SUMÁRIO}

Página

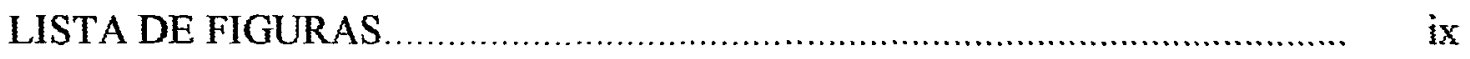

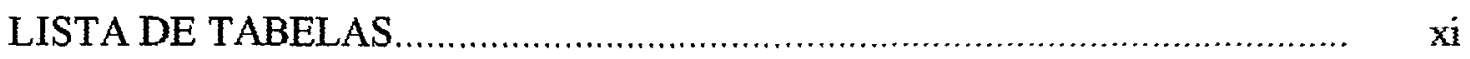

RESUMO

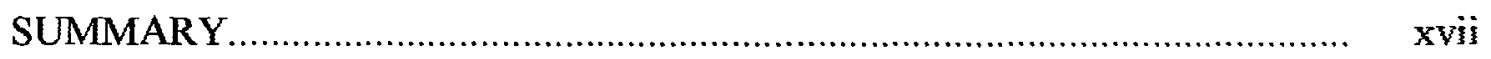

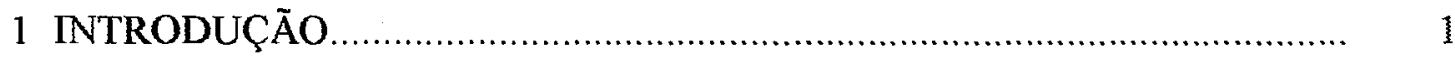

2 REVISÃO DE LITERATURA ….............................................................

2.1 Aspectos Gerais da Citricultura Brasileira ............................................... 3

2.2 Características da laranjeira 'Pêra' .................................................................. 5

2.3 Clones de laranjeira 'Pêra' ........................................................................ 7

2.4 Guignardia citricarpa e Mancha Preta dos Citros....................................... 10

2.5 Resistência de plantas a patógenos............................................................. 15

2.6 Interação planta $x$ patógeno.................................................................... 17

3 MATERIAL E MÉTODOS................................................................. 19

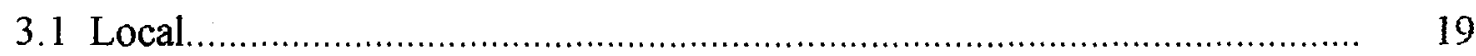

3.2 Clones de laranjeira 'Pêra' ..................................................................... 19

3.3 Isolado de Guignardia citricarpa................................................................. 20

3.4 Meios de cultura................................................................................... 21

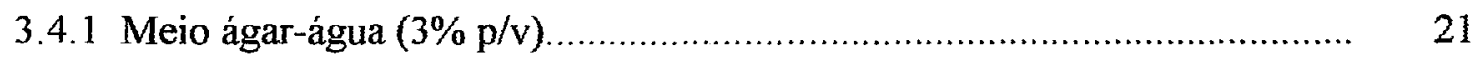

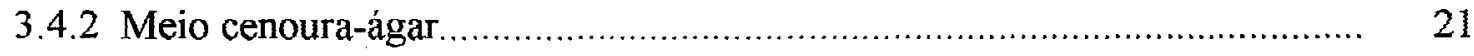

3.4.3 Meio cenoura-ágar-glicose ................................................................... 21 
3.5 Quantificação e distribuição da incidência e da severidade dos sintomas da Mancha Preta dos Citros ............................................................................. 22

3.6 Capacidade reprodutiva de $G$. citricarpa em folhas autoclavadas in vitro..... 23

3.7 Indução de estruturas reprodutivas de G. citricarpa em folhas destacadas.... 24

3.8 Colonização natural das folhas por G. citricarpa.......................................... 25

3.9 Produção de frutos ..................................................................................... 25

3.10 Queda de folhas e frutos......................................................................... 26

3.11 Desenvolvimento vegetativo das plantas............................................ 26

3.12 Características externas dos frutos ............................................................. 27

3.12.1 Severidade da Mancha Preta dos Citros na amostra de frutos.................. 27

3.12.2 Coloração da casca dos frutos................................................................... 27

3.12.3 Morfologia dos frutos........................................................................ 28

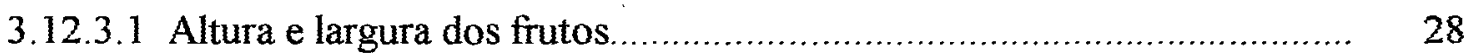

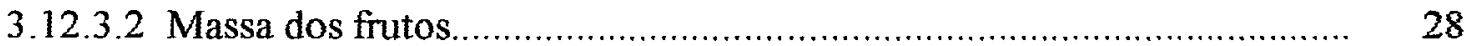

3.12.3.3 Formato, forma da base e do ápice dos frutos....................................... 28

3.12.3.4 Ângulo e achatamento da região basal do fruto................................... 29

3.12.3.5 Espessura da casca, do mesocarpo e do epicarpo dos frutos.................. 30

3.13 Características internas dos frutos.......................................................... 31

3.13.1 Rendimento de suco ................................................................. 31

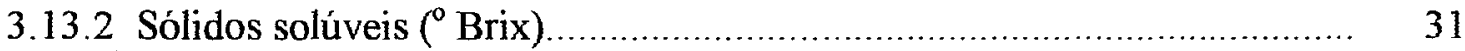

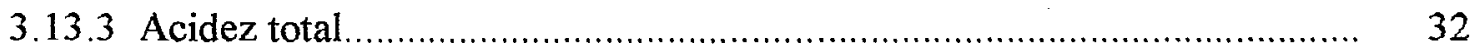

3.13.4 Relação sólidos solúveis: acidez (Ratio) .............................................. 32

3.13.5 Índice tecnológico ( $\mathrm{kg}$ sólidos solúveis por caixa) ............................... 32

3.14 Porcentagem de luz no interior das plantas.............................................. 33

4 RESULTADOS E DISCUSSÃO ............................................................... 34

4.1 Quantificação e distribuição da incidência e da severidade dos sintomas da 'Mancha Preta dos Citros.................................................................................... 34

4.2 Capacidade reprodutiva de G. citricarpa em folhas autoclavadas in vitro.... 39

4.3 Indução de estruturas reprodutivas de G. citricarpa em folhas destacadas.... 42

4.4 Colonização natural das folhas por G. citricarpa ......................................... 44 


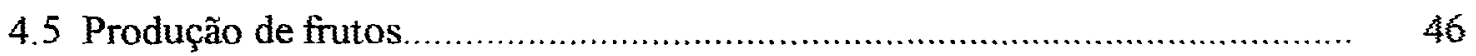

4.6 Queda de folhas e frutos..................................................................... 47

4.7 Desenvolvimento vegetativo das plantas................................................. 53

4.8 Características externas dos frutos.......................................................... 55

4.8.1 Severidade da Mancha Preta dos Citros na amostra de frutos..................... 55

4.8.2 Coloração da casca dos frutos............................................................. 56

4.8.3 Morfologia dos frutos.................................................................... 57

4.8.3.1 Altura e largura.............................................................................. 57

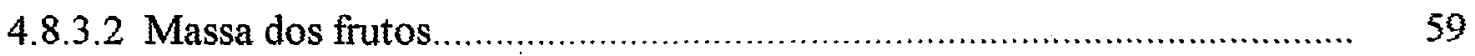

4.8.3.3 Formato, forma da base e do ápice dos frutos..................................... 60

4.8.3.4 Ângulo e achatamento da região basal do fruto ..................................... 61

4.8.3.5 Espessura da casca, do mesocarpo e do epicarpo dos frutos.................. 62

4.9 Características internas dos frutos......................................................... 66

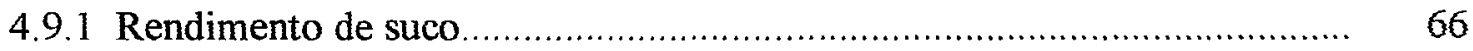

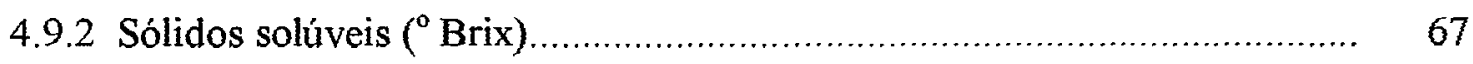

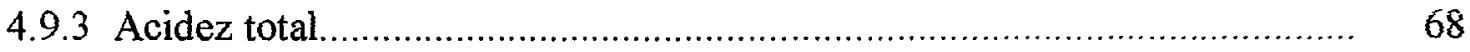

4.9.4 Relação sólidos solúveis: acidez (Ratio) ……......................................... 70

4.9.5 Índice tecnológico ( $\mathrm{kg}$ sólidos solúveis por caixa) .................................... 71

4.10 Porcentagem de luz no interior das plantas............................................. 72

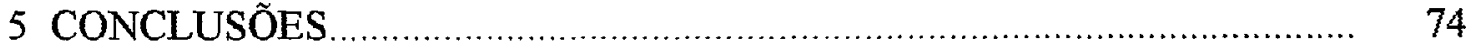

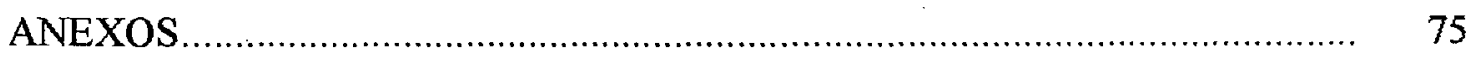

REFERÊNCIAS BIBLIOGRÁFICAS ............................................................... 80 


\section{LISTA DE FIGURAS}

Página

1 Escala de cores para os frutos .................................................................. 28

2 Representação do achatamento (a) e do ângulo do ombro (b) dos frutos......

3 Relação incidência - severidade da Mancha Preta dos Citros $\left(R^{2}=0,92\right)$ avaliada em dez clones de laranjeira 'Pêra' e cinco variedades afins, em Cordeirópolis-SP, safra 1999.

4 Relação incidência - soveridade da Mancha Preta dos Citros $\left(R^{2}=0,81\right)$ avaliada em dez clones de laranjeira 'Pêra' e cinco variedades afins, em Cordeirópolis-SP, safra 2000.

5 Correlação entre frutos para comercialização com notas de severidade até 2, 3 e 4 e a incidência da Mancha Preta dos Citros, safra 1999

6 Correlação entre frutos para comercialização com notas de severidade até 2, 3 e 4 e a incidência da Mancha Preta dos Citros, safra 2000

7 Estruturas reprodutivas produzidas in vitro, (meio ágar-água a 3\%), por $G$. citricarpa, em folhas previamente autoclavadas de clones de laranjeira 'Pêra', aos 28 dias.

8 Curva anual da média de folhas caidas em $1 \mathrm{~m}^{2}$ de dez clones de laranjeira 'Pêra' e cinco variedades afins, obtida mensalmente de agosto de 1999 a dezembro de 2000, em Cordeirópolis-SP. 
9 Curva anual da média de folhas caídas em $1 \mathrm{~m}^{2}$ de dez clones de laranjeira 'Pêra' e cinco variedades afins, obtida quinzenalmente de agosto de 1999 a dezembro de 2000 , em Cordeirópolis-SP

10 Porcentagem de frutos caídos com lesões de Mancha Preta dos Citros, em cinco avaliações quinzenais, de julho a setembro, nas safras de 1999 e 2000, em Cordeirópolis-SP

11 Número de frutos caídos com sintomas da Mancha Preta dos Citros na região lateral, obtidos em cinco avaliações quinzenais, de julho a setembro, nas safras de 1999 e 2000 , em Cordeirópolis-SP

12 Número de frutos caidos com sintomas da Mancha Preta dos Citros na região do pedúnculo, obtidos em cinco avaliações quinzenais, de julho a setembro, nas safras de 1999 e 2000 , em Cordeirópolis-SP

13 Número de frutos caidos com sintomas da Mancha Preta dos Citros na região do ápice, obtidos em cinco avaliações quinzenais, de julho a setembro, nas safras de 1999 e 2000 , em Cordeirópolis-SP. 


\section{LISTA DE TABELAS}

Página

1 Índice de severidade (notas de $0 \mathrm{a} 6$ ) e incidência (\% de frutos com lesões) da Mancha Preta dos Citros em dez clones de laranjeira 'Pêra' e cinco variedades afins, em Cordeirópolis-SP, safras 1999 e 2000

2 Distribuição da incidência (\% de frutos com lesões) e da severidade (notas de 0 a 6) da Mancha Preta dos Citros em diferentes alturas de avaliação, nas plantas de dez clones de laranjeira 'Pêra' e cinco variedades afins, em Cordeirópolis-SP, safras 1999 e 2000

3 Número médio de corpos de frutificação imaturos (CFI) e total (CFT), por $\mathrm{cm}^{2}$, e porcentagem de picnidios liberando esporos (\% PLE), produzidos in vitro, por Guignardia citricarpa, em folhas autoclavadas de dez clones de laranjeira 'Pêra', cinco variedades afins e duas variedades controle, aos 28 dias, safra 1999

4 Incidência (\%) de Guignardia citricarpa que naturalmente colonizou as folhas e porcentagem de área ocupada pelas estruturas reprodutivas do fungo, em dez clones de laranjeira 'Pêra' e cinco variedades afins, obtida por decomposição de folhas maduras, em Cordeirópolis-SP, safra 1999 
5 Incidência (\%) e número de colônias, por $\mathrm{cm}^{2}$ de área foliar, de Guignardia citricarpa, obtida através do isolamento do fungo em meio cenoura-ágar-glicose, de folhas maduras de dez clones de laranjeira 'Pêra' e cinco variedades afins, em Cordeirópolis-SP, safra 2000.

6 Produção de dez clones de laranjeira 'Pèra' e cinco variedades afins, em Cordeirópolis-SP, safras 1999 e 2000.

7 Queda de folhas sobre telas de $1 \mathrm{~m}^{2}$, colocadas sob a copa de dez clones de laranjeira 'Pêra' e cinco variedades afins, em Cordeirópolis-SP. As avaliações foram realizadas quinzenalmente de agosto a dezembro de 1999

8 Número de folhas caídas sobre telas de $1 \mathrm{~m}^{2}$, colocadas sob a copa de dez clones de laranjeira 'Pêra' e cinco variedades afins, em Cordeirópolis-SP. As avaliações foram realizadas quinzenalmente, de janeiro a dezembro de 2000

9 Volume e área de projeção da copa das plantas de dez clones de laranjeira 'Pêra' e cinco variedades afins, em Cordeirópolis-SP, safra 1999.

10 Índice de severidade da Mancha Preta dos Citros (notas de 0 a 6) na amostra de dez frutos, para ańlise de qualidade, em dez clones de laranjeira 'Pêra' e cinco variedades afins, em Cordeirópolis-SP, safras 1999 e 2000

11 Coloração da casca (Notas de 1 a 6 ) atribuída aos frutos de dez clones de laranjeira 'Pêra' e cinco variedades afins, em Cordeirópolis-SP, outubro de 1999 e setembro de 2000 .

12 Altura, largura e relação entre a altura e a largura (A/L) de frutos maduros de dez clones de laranjeira 'Pêra' e cinco variedades afins, em Cordeirópolis-SP, safra 1999 
13 Altura, largura e relação entre a altura e a largura (A/L) de frutos maduros de dez clones de laranjeira 'Pêra' e cinco variedades afins, em Cordeirópolis-SP, safra 2000

14 Massa média (g) de dez frutos de dez clones de laranjeira 'Pêra' e cinco variedades afins, em Cordeirópolis-SP, safras 1999 e 2000

15 Ângulo e achatamento da região basal, próxima ao pedúnculo dos frutos de dez clones de laranjeira 'Pêra' e cinco variedades afins, em CordeirópolisSP, safra 2000 .

16 Espessura de três regiōes (superior, mediana e inferior) e espessura média do epicarpo $(\mathrm{cm})$, de quatro frutos de dez clones de laranjeira 'Pêra' e cinco variedades afins, em Cordeirópolis-SP, safra 1999

17 Espessura de três regiões (superior, mediana e inferior) e espessura média do epicarpo $(\mathrm{cm})$, de quatro frutos de dez clones de laranjeira 'Pêra' e cinco variedades afins, em Cordeirópolis-SP, safra 2000.

18 Espessura de três regiões (superior, mediana e inferior) e espessura média do mesocarpo (cm), de quatro frutos de dez clones de laranjeira 'Pêra' e cinco variedades afins, em Cordeirópolis-SP, safra 1999

19 Espessura de três regiões (superior, mediana e inferior) e espessura média do mesocarpo $(\mathrm{cm})$, de quatro frutos dez clones de laranjeira 'Pêra' e cinco variedades afins, em Cordeirópolis-SP, safra 2000

20 Espessura de três regiões (superior, mediana e inferior) e espessura média da casca (cm), de quatro frutos de dez clones de laranjeira 'Pêra' e cinco variedades afins, em Cordeirópolis-SP, safra 1999.

21 Espessura de três regiões (superior, mediana e inferior) e espessura média da casca $(\mathrm{cm})$, de quatro frutos de dez clones de laranjeira 'Pêra' e cinco variedades afins, em Cordeirópolis-SP, safra 2000 
22 Rendimento médio de suco (\%), de dez frutos de dez clones de laranjeira 'Pêra' e cinco variedades afins, em Cordeirópolis-SP, safras 1999 e $2000 \ldots 66$

23 Sólidos solúveis ( ${ }^{\circ} \mathrm{Brix}$ ), de dez frutos de dez clones de laranjeira 'Pêra' e cinco variedades afins, em Cordeirópolis-SP, safras 1999 e 2000

24 Acidez total (\%), de dez frutos de dez clones de laranjeira 'Pêra' e cinco variedades afins, em Cordeirópolis-SP, safras 1999 e 2000

25 Relação sólidos solúveis:acidez (Ratio) de dez frutos de dez clones de laranjeira 'Pêra' e cinco variedades afins, em Cordeirópolis-SP, safras 1999 e 2000

26 Índice tecnológico ( $\mathrm{kg}$ de sólidos solúveis/cx), de dez clones de laranjeira 'Pêra' e cinco variedades afins, em Cordeirópolis-SP, safras 1999 e $2000 .$.

27 Porcentagem de luz no interior das plantas de dez clones de laranjeira 'Pêra' e cinco variedades afins, mensurada com 0 auxilio de um quantômetro, em Cordeirópolis-SP, safra 2000 


\section{RESISTENCIA DE CLONES DE LARANJEIRA 'PÊRA' E VARIEDADES AFINS À MANCHA PRETA DOS CITROS}

Autor: EVANDRO HENRIQUE SCHINOR Orientador: Prof. Dr. FRANCISCO DE ASSIS ALVES MOURÃO FILHO

\section{RESUMO}

A Mancha Preta dos Citros ou Pinta Preta (MPC), causada pelo fungo Guignardia citricarpa, vem provocando graves e crescentes prejuizos econômicos à cultura, nos últimos 20 anos. O presente trabalho foi desenvolvido no Centro de Citricultura 'Sylvio Moreira' (CCSM) do Instituto Agronômico de Campinas, no município de Cordeirópolis-SP. Procurou-se detectar possíveis diferenças entre dez clones de laranjeira 'Pêra' (Citrus sinensis L. Osbeck) e cinco variedades afins, quanto à suscetibilidade à MPC. Os clones de 'Pêra' avaliados foram: Vimusa; EEL; GS 2000 (IAC 2000); Olimpia 15161; Bianchi; R. Gullo 1569/244; Dibbern C.V.; Premunizada 1743/82; e as variedades afins foram: Corsa Tardia, Lamb Summer, Ovale 968, Ovale San Lio 969, e Redonda C.N, enxertados em limoeiro 'Cravo', instalados desde 1980, no CCSM. Os trabalhos experimentais incluiram investigações sobre a avaliação e distribuição da severidade dos sintomas nas plantas; indução de estruturas in vitro, em folhas previamente autoclavadas; indução de estruturas reprodutivas do fungo em folhas maduras destacadas; e quantificação da densidade de colonização de G. citricarpa, através de isolamento. A comparação entre os diferentes clones também foi realizada 
através de estudos de correlação entre a severidade dos sintomas da doença e das variáveis ou dados biométricos, que seguem: queda de folhas, desenvolvimento vegetativo (porte) e penetração da luz no interior das plantas. Quanto aos frutos, a severidade foi correlacionada com: cor, formato, formas da base e do ápice, ângulo e achatamento, espessura do epicarpo, do mesocarpo e da casca e por fim com os dados de qualidade do suco (Brix, Acidez e Ratio). Não houve diferenças significativas entre os dez clones de laranjeira 'Pêra' e as cinco variedades afins quanto à quantificação da incidência e severidade da MPC no campo, e à densidade de colonização natural das folhas (isolados $/ \mathrm{cm}^{2}$ ). A incidência e a severidade dos sintomas da doença são maiores na parte baixa das plantas, até 1 metro de altura, e menor acima de 2 metros, podendo-se salientar que há influência na infeç̧ão dos frutos pelos ascósporos (sexuais) e picnidiósporos (assexuais), através de respingos d'água. Ocorreu uma diferenciação entre as variedades quanto à capacidade reprodutiva de G. citricarpa em folhas mortas in vitro e quanto à indução de estruturas do fungo, através da porcentagem de área das folhas ocupadas por elas. Não houve correlação das características externas dos frutos como: coloração da casca, formato, forma da base, forma do ápice, ângulo e achatamento da região basal e espessura da casca, do mesocarpo e do epicarpo, com a severidade da doença. Não houve correlação das características internas dos frutos como: sólidos solúveis ('Brix), acidez total, e relação sólidos solúveis:acidez (ratio), com severidade da doença. Portanto, a Mancha Preta dos Citros não interfere nas qualidades organolépticas dos frutos, e sim, no aspecto visual dos mesmos. 


\title{
CITRUS BLACK SPOT RESISTANCE OF 'PERA' SWEET ORANGE CLONES AND SIMILAR VARIETIES
}

\author{
Author: EVANDRO HENRIQUE SCHINOR \\ Adviser: Prof. Dr. FRANCISCO DE ASSIS ALVES MOURÃO FILHO
}

\section{SUMMARY}

Citrus Black Spot (CBS), caused by Guignardia citricarpa, has prompted serious economic damages to the citrus industry in the last 20 years. The present work was developed at the Centro de Citricultura 'Sylvio Moreira' (CCSM) of the Instituto Agronômico de Campinas, in Cordeirópolis-SP. Evaluations were conducted to detect differences among ten 'Pêra' sweet orange Citrus sinensis (L.) Osbeck clones and five related varieties in regard to their susceptibility to CBS. The 'Pêra' sweet orange clones evaluated were: Vimusa, EEL, GS 2000 (IAC 2000), Olímpia 15161, Bianchi, R. Gullo 1569/244, Dibbern C.V., Premunizada 1743/82; and the related varieties were: Corsa Tardia, Lamb's Summer, Ovale 968, Ovale San Lio 969, and Redonda C.N. Trees were budded on Rangpur lime are planted in 1980, at the CCSM. Studies investigated the evaluation severity of symptoms and distribution on the plants; induction of structures in vitro in leaves previously autoclaved; induction of fungus reproductive structures in mature leaves; and quantified density of colonization of $G$. citricarpa by means of isolation. The comparison among different clones was also accomplished by determining correlations between the severity of disease symptoms and the variables: leaf drop, 
vegetative growth, and light penetration inside the plants. In regard to fruit, the severity was correlated with: color; fruit shape; base and apex shape; angle and flattening; epicarp, mesocarp and peel thickness; and with juice quality (soluble solids and soluble solids to acidity ratio). The relationship for quantification of severity of CBS incidence in the field and the density of natural leaves colonization (isolates $/ \mathrm{cm}^{2}$ ) was not significant. The incidence and the severity of the disease symptoms are greater in the low part of the plants, up to 1 meter height, and smaller above 2 meters, probably because of the influence of fruit infection by ascospores (sexual) and picnidiospores (asexual) through water splash. Differentiation among the varieties was detected based on the reproductive capacity of $G$. citricarpa on dead leaves in vitro and also based on the induction of fungus structures, as evaluated by the percentage of area of the leaves occupied by them. There was not a significant correlation for fruit external characteristics, such as peel color, fruit shape, base and apex shape, basal area angle and flattening, and peel thickness of either mesocarp and epicarp with the severity of disease. Similarly there was not a correlation for fruit internal characteristics such as soluble solids, total acidity, and soluble solids to acidity (ratio), with the severity of disease. Therefore, the CBS of the fruit does not interfere on the fruit organoleptic quality. However, visual aspect of fruit is severely depressed. 


\section{INTRODUÇÃO}

A citricultura constitui importante segmento na estrutura sócio-econômica do Brasil, podendo ser caracterizada como uma das mais típicas atividades agro-industriais do país. O Brasil assumiu nas últimas décadas a liderança mundial de produção de laranjas, com 16,524 milhões de toneladas (safra 1999/2000), seguido pelos Estados Unidos, com 11,894 milhões de toneladas, não havendo a curto e médio prazos, perspectivas de mudanças em tal panorama. No Brasil, o Estado de São Paulo se destaca como o maior produtor de citros, com aproximadamente $80 \%$ da produção total do país (FNP Consultoria \& Comércio, 2001).

A laranjeira 'Pêra', principal variedade da citricultura paulista, responsável por $41 \%$ do total de plantas (Amaro \& Maia, 1997), é preferida pelos produtores devido às boas qualidades dos seus frutos, tanto para a fabricação de suco concentrado congelado, como para seu consumo in natura; à sua boa adaptação às condições climáticas do Estado de São Paulo e também à característica de produzir frutas tẹmporãs, ou seja, fora de época. Sua produção é boa, atingindo em média $250 \mathrm{~kg}$ de frutos por planta (Figueiredo, 1991).

Apesar dos impactos na economia brasileira, a citricultura já passou por muitos entraves, na maioria das vezes, relacionado a doenças. A maior ameaça ocorreu em 1937 com o aparecimento do vírus da tristeza, que praticamente eliminou 10 milhões de plantas enxertadas em laranjeira 'Azeda', atrasando o desenvolvimento da citricultura brasileira em uma dezena de anos. Outro problema foi o exocorte, surgido em conseqüência da solução encontrada para a tristeza, mas foi brilhantemente solucionado com a adoção do emprego dos clones nucelares. Em 1957, surge o cancro cítrico, trazido do Japão para o Estado de São Paulo, e mais uma vez a citricultura brasileira teve uma 
perda significativa, com 300 mil plantas erradicadas. No ano de 1987 surge uma nova doença denominada de Clorose Variegada dos Citros (CVC), causada pela bactéria Xylella fastidiosa, que afetou a produção citrícola e exigiu grande atenção dos pesquisadores.

Em 1993, foi assinalada, nos pomares paulistas, uma nova doença denominada de Mancha Preta dos Citros, causada pelo fungo Guignardia citricarpa Kiely, infectando plantas de limoeiros verdadeiros e laranjeiras doces de maturação tardia, nos municípios de Conchal e Engenheiro Coelho, e atualmente, vem se alastrando nas regiões citrícolas do Estado. Esta doença tem sido responsável por grandes prejuizos em várias regiôes produtoras de citros no mundo, sendo constatadas perdas superiores a $80 \%$ na Austrália e África do Sul. Além disso, para o consumo in natura, a aparência dos frutos é de vital importância para o mercado interno, e para a exportação, a Mancha Preta dos Citros tem sido designada como barreira fitossanitária, principalmente no mercado Europeu, representando um fator limitante para esse tipo de exploração, e consequentemente, comprometendo a exportação brasileira de frutas frescas.

Esta doença afeta todas as variedades de laranjeira, principalmente, as de maturação média-tardia ('Pêra') a tardias ('Valência'e 'Natal'). Com exceção da limeira ácida 'Tahiti', da laranjeira 'Azeda' e alguns de seus híbridos, todas as variedades comerciais são suscetíveis, principalmente os limoeiros verdadeiros. Ela apresenta no campo diferenças de suscetibilidade devido à época de maturação dos frutos e aos diferentes genótipos, sendo mais evidentes entre espécies e variedades cítricas. Entretanto, há um grande desconhecimento da suscetibilidade entre os diferentes clones existentes dentro das variedades.

Tendo em vista as considerações acima mencionadas, os danos econômicos que a Mancha Preta dos Citros já vem causando e, sabendo-se das diferenças de suscetibilidade entre as espécies e variedades, é de grande importância a caracterização da resistência ao nivel de clones dentro das variedades cítricas. Portanto, o objetivo do presente trabalho foi o de estudar e comparar dez clones de laranjeira 'Pêra' e cinco variedades afins quanto à suscetibilidade à doença, determinando qual ou quais os possiveis fatores envolvidos nesta diferenciação. 


\section{REVISÃo DE LITERATURA}

\subsection{Aspectos Gerais da Citricultura Brasileira}

A citricultura brasileira pode ser caracterizada como uma das mais típicas atividades agro-industriais, apoiada em demanda de produtos in natura, ou seja, frutas frescas, e produtos processados, representados por suco concentrado, pectina e óleos essenciais (Instituto de Economia Agrícola, 1997). Nas últimas décadas, o Brasil vem liderando a produção mundial de laranjas, sendo que na safra 1999/2000, produziu 16,524 milhões de toneladas métricas, seguido pelos Estados Unidos, com produção de 11,894 milhões de toneladas métricas (FNP Consultoria \& Comércio, 2001), não havendo a curto e médios prazos perspectivas de mudanças em tal panorama.

O Brasil é líder absoluto no comércio internacional de suco de laranja concentrado congelado (SLCC), participando com aproximadamente $82 \%$ do volume comercializado internacionalmente, entretanto enfrenta numerosas sanções, em especial barreiras tarifárias (FNP Consultoria \& Comércio, 2001).

Ao contrário de outras atividades agropecuárias pertencentes a complexos agroindustriais altamente dinâmicos, que tenderam a se espalhar para as novas regiões de fronteira agrícola, tal como a cultura da soja, a citricultura vem apresentando a tendência de se concentrar em poucas regiões do país (Igreja et al., 2000). As estimativas para 2000 apontavam que apenas quatro estados produtores (São Paulo, Sergipe, Bahia e Minas Gerais) detinham $92,9 \%$ do total da produção brasileira de laranjas, com uma área colhida em torno de 908 mil hectares. São Paulo é o maior Estado brasileiro produtor de laranja, com cerca de 388 milhões de caixas de $40,8 \mathrm{Kg}$ produzidas na safra 
de $1999 / 2000$, sendo que desse montante $72,2 \%$ foram utilizados pela indústria de suco concentrado e 27,8\% para o consumo interno (FNP Consultoria \& Comércio, 2001).

A elevada concentração da produção de laranja e do suco concentrado no "cinturão citrícola" paulista, onde São Paulo detém cerca de $50 \%$ da produção mundial e $80 \%$ das transações mundiais de suco concentrado, levou Neves \& Neves (1996) a denominá-lo de commodity sui generis em face dos localizados impactos alocativos e distributivos de sua produção, incomuns em outras explorações agrícolas. Cerca de $9 \%$ de todo o agronegócio brasileiro vem da laranja, oitavo produto da pauta de exportações do país (FNP Consultoria \& Comércio, 2001), sendo que a cadeia produtiva de citros ocupa cerca de um milhão de hectares, aproximadamente 20 mil propriedades agricolas, agregando em torno de 140 mil famílias (60 mil apanhadores e 80 mil empregados e pequenos plantadores) Gama et al. (2000).

O parque industrial brasileiro vem mostrando um declinio, representado pela queda de 6,3 \% na produção de suco de laranja paulista, nos anos 1995 a 1998, com expressivos reflexos na cadeia. Em contrapartida, o mercado internacional de suco cítrico cresceu 18,9\% (SECEX, 1999, citado por Gama, 2000). O cancro cítrico e a CVC estão entre os principais responsáveis pela diminuição do parque citrícola nos últimos anos. Eram 180 milhões de árvores em produção, há dois anos, o que foi reduzido para 169 milhões, em vista desses problemas fitossanitários (FUNDECITRUS, 1999).

No inicio da década de oitenta a Mancha Preta dos Citros, causada pelo fungo Guignardia citricarpa Kiely, foi descrita no Estado do Rio de Janeiro, causando prejuizos significativos (Robbs et al, 1980). No final da mesma década, surgiu de forma epidêmica na região citrícola do Vale do Caí, no Rio Grande do Sul (Robbs \& Bittencourt, 1995). E nos pomares paulistas, foi assinalada por Goes \& Feichtenberger (1993), infectando plantas de limões verdadeiros e laranjas doces de maturação tardia, nos municípios de Conchal e Engenheiro Coelho. Em ataques severos, esta doença pode causar a queda prematura dos frutos, e tem sido responsável por grandes prejuizos em várias regiões produtoras de citros no mundo, sendo constatadas perdas superiores a $80 \%$ na Austrália e África do Sul (Klotz, 1978). Além disso, para o consumo in natura, 
a aparência dos frutos é de vital importância para o mercado interno; $e$, para a exportação, esta doença tem sido designada como barreira fitossanitária, principalmente no mercado Europeu. Dessa maneira, a Mancha Preta dos Citros representa um fator limitante para esse tipo de exploração, comprometendo a exportação brasileira de citros, tendo que ser melhor estudada, principalmente no referente à resistência de genótipos à doença.

\subsection{Características da laranjeira 'Pêra'}

A laranjeira 'Pêra' foi introduzida no Brasil há muito tempo, sendo atualmente a variedade mais importante do país. Alguns autores brasileiros admitem que a laranjeira 'Pêra' seja a Lamb's Summer, sendo esta variedade originária de um "seedling" encontrado no município de Volusia, na Flórida, provavelmente antes de 1897. Outros, levam em consideração a semelhança entre a 'Pêra' e a variedade Verna, da Espanha (Figueiredo, 1991). Além de Hasse (1997), admitir que a origem da laranjeira 'Pêra' tenha ocorrido no Estado do Rio de Janeiro. Portanto, são aventadas diversas hipóteses para a sua origem, mas sem comprovação clara, acreditando-se que a laranjeira 'Pêra' possa ser originária de outras variedades devido às semelhanças evidentes (Donadio et al., 1995), como descrito acima.

A laranjeira 'Pêra', apesar de ter passado por períodos de menor interesse devido à tristeza, sempre ocupou lugar de destaque em nossa citricultura, antes mesmo do periodo de industrialização. No entanto, sua importância cresceu após a obtenção de clones premunizados e graças à grande demanda da indústria (Donadio et al., 1995). Atualmente, no Estado de São Paulo, a 'Pêra', é a variedade mais plantada, participando, em número de plantas, com $41 \%$ do total relativo a laranjeiras (Amaro \& Maia, 1997). Tem boa adaptação às condições climáticas do Estado. Os frutos têm como destino o consumo in natura, nos mercados interno e externo, e para suco concentrado (Figueiredo, 1991), sendo preferidos para a extração de suco fresco para consumo no mercado interno (Teófilo Sobrinho et al., 1996). 
Em 1938 o Dr. Sylvio Moreira iniciou o melhoramento da laranjeira 'Pêra', continuado posteriormente por outros pesquisadores, sempre dando atenção ao melhoramento em relação à tolerância à tristeza. Apesar da obtenção em 1967 de alguns clones mais tolerantes ao virus e dos estudos comparativos realizados em 1971 entre vários clones novos e velhos, só a partir da obtenção dos clones premunizados e de clones infectados naturalmente com estirpes fracas do virus, foi que a laranjeira 'Pêra' voltou a ter grande uso comercial (Donadio et al., 1995).

As plantas desta variedade apresentam vigor mais reduzido por terem os seus tecidos intolerantes ao virus da tristeza. Muller et al. (1971) informam que a 'Pêra' é uma das mais intolerantes ao virus da tristeza, tendo sido nessa variedade que primeiramente se notou os prejuizos causados por esta doença em pomares comerciais, levando à necessidade da pré-imunização com estirpes fracas do virus. A laranjeira 'Pêra' enxertada em limoeiro 'Cravo', também é suscetivel ao declinio dos citros, o qual foi constatado visualmente por Teófilo Sobrinho et al. (1996) em experimento de seleção de clones na região de Araraquara, SP.

O melhoramento de citros encontra na obtenção de clones nucelares a principal possibilidade de eliminação de viroses. Já na laranjeira 'Pêra', o processo não é suficiente para evitar danos causados pelo vírus da tristeza, sendo constatado por Passos $\&$ Cunha Sobrinho (1971) que o clone nucelar apresenta $27 \%$ de sintomas fortes (caneluras), e os clones velhos, $84 \%$ de sintomas fortes de tristeza. As mudas originárias de clones nucelares apresentam espinhos, que está ligada à fase juvenil e não ao vigor vegetativo, pois estas mudas são mais vigorosas que aquelas originadas de clones velhos, para um mesmo clone, devido à ausência de viroses (Sampaio \& Barbin, 1978).

A principal época de colheita dessa variedade para as condições do Estado de São Paulo, ocorre entre julho a meados de novembro, sendo considerada de maturação tardia. Normalmente, ocorrem floradas temporãs, fazendo com que se registrem algumas outras frutificações no decorrer do ano. Os frutos tem forma ovalada, com 3 a 4 sementes e peso médio de $145 \mathrm{~g}$; a casca é de cor alaranjada, de espessura fina a média, quase lisa e com vesículas de óleo em nível. Tem polpa de cor laranja viva e textura firme (Figueiredo, 1991). 
As árvores são de porte médio, galhos mais ou menos eretos, folhas acuminadas; bem produtivas; os frutos conservam-se na planta, alguns meses depois de maduros. As flores têm cálice persistente, com sépalas de cor verde clara. A corola apresenta pétalas de coloração branca e textura fina. Maiores que as sépalas, as pétalas têm ápice agudo e a base truncada (Donadio et al., 1995).

Domingues et al. (1997), estudando caracteristicas morfológicas de doze clones de laranjeira 'Pêra', relatou que todos apresentaram um formato típico da variedade, ou seja, largamente obovalados, e quanto ao número de sementes, o clone Pirangi apresentou, em média, 7,3 sementes por fruto, seguido do clone Olimpia, com 5,7 sementes por fruto, estando acima da média para a variedade 'Pêra'.

A produção de laranja 'Pêra Bianchi' mostra-se correlacionada com a idade do pomar e com totais mensais de precipitação que ocorrem no periodo anterior à colheita, sendo que as precipitaçōes que ocorrem nos meses de fevereiro, abril, julho e outubro do ano anterior à colheita, e janeiro, fevereiro e junho do ano da colheita mostram-se correlacionadas negativamente com a produção. Já as chuvas que ocorrem nos meses de março, maio, junho, agosto, setembro, novembro e dezembro do ano anterior à colheita, e março e abril do ano da colheita, mostram-se correlacionadas positivamente com a produção (Tubelis et al., 1992).

Em vários trabalhos foram determinadas as características médias dos frutos de 'Pêra'. As diferenças obtidas entre os dados para a mesma variedade podem ser devido às condições ecológicas de cada local, aos clones, à idade das plantas e inclusive aos métodos de análise (Donadio et al., 1995).

\subsection{Clones de laranjeira 'Pêra'}

Allard (1971) definiu clone como um grupo de organismos que descendem por mitoses de um antecessor comum. Como o fenótipo de um indivíduo é resultante da interação do genótipo com o ambiente, plantas de um mesmo clone podem ter diferentes aspectos, em função do clima, solo e manejo das plantas, embora sua genética seja idêntica. 
Para Salibe (1996), o termo clone pode ser definido como o conjunto de indivíduos resultantes da propagação vegetativa de uma planta original. Esta deve ter sido selecionada dentro da variedade, por alguma característica desejável, como por exemplo maior produtividade, maturação dos frutos mais precoce ou tardia ou resistência a um problema fitossanitário

Os clones de laranjeira 'Pêra', atualmente mais cultivados no Brasil, têm os nomes de Premunizado, Bianchi, Olimpia, Gullo, Dibbern, Vimusa, Pirangi, CNPMF (A-1, A-6, D-9, E-6, etc), Sete Lagoas e outros. Alguns desses clones são de origem nucelar e outros representam linhagens antigas, chamadas clones velhos. Todos têm 0 nome genérico de laranja 'Pêra do Rio' ou 'Pêra Coroa'. Alguns desses clones, como a 'Pêra Bianchi', embora dêem origem a plantas produtivas, têm a tendência de induzir menor número de frutos temporãos (fora de época). Os clones de laranjeira 'Pêra' cultivados diferem muito quanto à produtividade, qualidade dos futos e adaptą̧ão aos diferentes tipos de clima do planalto paulista (Salibe, 1996).

Teófilo Sobrinho et al. (1977 e 1981), realizando o primeiro experimento de seleção de clones de laranjeira 'Pêra', com delineamento estatístico no Estado de São Paulo, relataram que os clones Premunizado, Bianchi e EEL, foram os que induziram o maior vigor às plantas e também proporcionaram os maiores índices de produtividade. Os mesmos autores informaram ainda que os clones Bianchi e EEL apresentaram caneluras leves e o Premunizado, moderadas. Com relação à qualidade dos frutos, os clones Bianchi, Premunizado e EEL destacaram-se dos demais.

Segundo Teófilo Sobrinho et al. (1987), os clones mais produtivos nas primeiras colheitas, geralmente, são também durante a fase adulta das plantas para um mesmo porta-enxerto. Além do que, os clones mais produtivos, em experimento de seleção de clones de laranjeira 'Pêra', são aqueles que apresentam predominância de sintomas fracos de caneluras atribuidas ao virus da tristeza (Cunha Sobrinho et al., 1979).

Teófilo Sobrinho et al. (1989), dando continuidade aos seus trabalhos de seleção de clones de laranjeira 'Pêra', divulgaram resultados de seus experimentos, nos quais: Vimusa, Bianchi, Lamb's Sumer, Dibbern e o Premunizado 1743, foram os mais 
produtivos. Os mesmos autores relataram, ainda, que em posị̧ão intermediária vieram os clones: Gullo, Pirangi CV, Premunizado 1212 e EEL e por último, os clones Olimpia e Ovale.

Teófilo Sobrinho et al. (1992) informaram que para a região de Limeira-SP, os clones GS 2000, Premunizado 1743, EEL, Bianchi, Lamb's Summer e Vimusa foram os mais produtivos na média de oito safras. Quanto ao vigor, os clones que se destacaram foram: GS 2000, Premunizado 1743 e Ovale San Lio (969). Os clones Gullo 1569 e 1570 apresentaram caneluras severas. E concluíram que o clone GS 2000, pelo conjunto de todas as caracteristicas apresentadas, poderá ser mais uma opção para os produtores de citros, sendo lançada no ano de 2000, como 'Pêra' IAC 2000.

Após um período de dez anos de estudo, na região de Araraquara-SP, Teófllo Sobrinho et al. (1996) encontraram que os clones Vimusa, Bianchi, Lamb's Summer, Premunizado 1743 e Dibbern foram os mais produtivos, e que apenas o Vimusa esteve em todos os anos entre os três mais produtivos, exceto en um ano quando ocupou o quarto lugar. Os clones Ovale e Gullo foram os menos produtivos. Todos os clones apresentaram sintomas moderados de caneluras atribuidos à virose tristeza. Os autores concluíram que o clone Vimusa, pelo conjunto das caracteristicas avaliadas, poderia ser mais uma opção para os citricultores da região.

Teófilo Sobrinho et al. (1984) relataram que a produção de laranjeira 'Pêra Bianchi' sobre diferentes porta-enxertos, não apresentou diferenças significativas no total de seis anos de colheita. Mourão Filho et al. (1991) revelaram que os portaenxertos tangerineiras 'Cleópatra' e 'Sunki' e limoeiro 'Rugoso da Flórida' induziram a um maior desenvolvimento das plantas de laranjeira 'Pêra Premunizada'. Os portaenxertos limoeiros 'Volkameriano', 'Rugoso da Flórida' e 'Cravo' e as tangerineiras 'Cleópatra' e 'Sunki', induziram as maiores produções totais. Os maiores valores de indice de eficiência (produção $\mathrm{em} \mathrm{kg} \mathrm{m}^{-3}$ de copa) foram constatados em plantas de laranjeira 'Pêra' sobre 'Trifoliata', citrangeiro 'Carrizo' e limoeiro 'Cravo'.

Quanto à época de maturação dos frutos de doze clones de laranjeira 'Pêra", Domingues et al. (1997), através de análise multivariada com o uso da técnica de agrupamento para os dados de ${ }^{\circ} \mathrm{Brix}$ e acidez, obtiveram quatro grupos: o primeiro 
formado pelos clones Vimusa, EEL, e Olímpia; o segundo pelo GS 2000, Bianchi, Dibbern e Premunizado 1743; o terceiro pelo Premunizado 1212, R. Gullo 1569 e R. Gullo 1570; e o último grupo formado pelos clones Pirangi e Lamb's Summer. O primeiro grupo atingiu um nivel de ratio igual a quatorze, 20 dias antes do segundo e terceiro grupos e 60 dias antes do quarto grupo. Estes dados estão de acordo com Teófilo Sobrinho et al. (1996), sendo que, os clones Vimusa, Bianchi, Dibbern e Premunizado 1743, apresentaram frutos com características semelhantes, enquanto que o clone Lamb's Summer era de maturação mais tardia.

Devido à grande importância da variedade 'Pêra' $\mathrm{e}$ de seus clones para $O$ mercado interno de frutas frescas e para o processamento de suco concentrado, torna-se fundamental uma caracterização mais detalhada de alguns clones em relação à Mancha Preta dos Citros, uma doença que vem atingindo esta variedade de forma severa devido à época de maturação de seus frutos ser tardia, e principalmente por esta doença ter se tornado uma barreira fitossanitária à exportação de fruta fresca para o mercado Europeu.

\subsection{Guignardia citricarpa e Mancha Preta dos Citros}

Segundo Sivanesan (1984), Guignardia citricarpa é um Ascomiceto, Loculoascomiceto, da ordem Dothideales e família Dothideacea. Inicialmente, a fase anamórfica ou imperfeita do fungo foi considerada como Phoma citricarpa (McALp) Petrak (Fawcett, 1936). Atualmente, essa fase é referida como Phyllosticta citricarpa Van der Aa. A fase teleomórfica ou sexual corresponde a $G$. citricarpa Kiely (Kiely, 1948).

G. citricarpa produz ascocarpos ou peritécios somente em folhas em decomposição no solo (Kotzé, 1981). Em um estado de decomposição intermediário, em que as folhas caidas estejam secas, não quebradiças e com uma consistência igual a de papel, é quando os peritécios se encontram completos e maduros. Nunca se observam estas estruturas em etapas iniciais de decomposição e no final deste processo, em que a folha se quebra com o tato, encontrando-se apenas estruturas reprodutivas vazias (Alcoba et al., 2000). Os ascocarpos não são encontrados em lesões de frutos e folhas. 
Eles são isolados ou agregados, globosos (100-175 $\mu \mathrm{m}$ de diâmetro), apresentando um ostíolo circular e não papilado, medindo em torno de $16 \mu \mathrm{m}$ de diâmetro. Os ascos são cilíndrico-clavados, bitunicados, apresentando oito ascósporos em seu interior. Os ascósporos são unicelulares, hialinos, multigutulados, cilindricos com o centro dilatado (12,5-16 x 4,5-6,5 $\mu \mathrm{m})$, apresentando apêndices hialinos nas duas extremidades obtusas (Feichtenberger et al., 1997; Baldassari et al., 2001). O desenvolvimento dos peritécios nas folhas em decomposição, depende de infecções que tenham ocorrido durante o período de suscetibilidade. A disponibilidade de ascósporos depende, entre outros fatores, do momento da desfolha e da velocidade de decomposição das folhas, estando diretamente relacionado com a temperatura e as precipitações (Alcoba et al., 2000).

A fase anamórfica $P$. citricarpa produz picnidios em lesões de frutos e folhas e, ocasionalmente, no pedúnculo de frutos. Eles também são produzidos em grande número em folhas mortas. Os picnídios são de coloração marrom-escuro ou preta, solitários ou agregados, globosos (115-190 $\mu \mathrm{m}$ de diâmetro), apresentando um ostiolo levemente papilado e circular, de 12-14,5 $\mu \mathrm{m}$ de diâmetro (Feichtenberger et al., 1997). Os conidios apresentam forma obovóide a eliptica $(8-10,5 \times 5,5-7 \mu \mathrm{m})$ ou subglobosos, são hialinos, unicelulares, multigutulados, com um apêndice $(5-10 \mu \mathrm{m})$ hialino numa das extremidades (Feichtenberger et al., 1997; Baldassari et al., 2001). Normalmente os picnidiósporos ficam agregados devido à substância mucilaginosa que os recobre. Sob condições naturais, essa mucilagem apresenta-se de coloração creme claro, de aspecto brilhante (Baldassari et al., 2001). De acordo com Punithalingam \& Woodhams (1982), essa mucilagem serve de proteção contra o ressecamento das estruturas do fungo quando expostas em ambiente adverso.

G. citricarpa tem sido relatada em alguns paises ou regiões onde os sintomas da Mancha Preta não foram observados. A presença do fungo em pomares cítricos não significa que a doença está presente. Há uma raça do fungo que infecta apenas os citros, entretanto, existe uma raça avirulenta que infecta uma ampla faixa de hospedeiros. Em meio ágar, a raça avirulenta cresce mais rápido que o patógeno da Mancha Preta, e somente ela produz ascocarpos maduros in vitro (Kotzé, 1988). 
A doença Mancha Preta dos Citros foi descrita pela primeira vez, em 1895, na Austrália, causando perdas significativas em laranjeira 'Valência', resultantes de infeç̧ões ocorridas nos pomares em fase de pós-colheita (Fawcett, 1936). O fungo $G$. citricarpa apresenta ampla faixa de hospedeiros compreendendo plantas de 20 familias diferentes em adição à familia Rutaceae (Kotzé, 1988), incluindo plantas como camélias, amendoeira e roseira (Klotz, 1973). No gênero Citrus, a doença ocorre em laranjeiras, tangerineiras, limoeiros e pomeleiros, sendo já constatada na África (Moçambique, Zimbabwe, Swazilândia e África do Sul), na Ásia (China, Filipinas, Taiwan e Indonésia), na Austrália, e na América do Sul (Argentina, Brasil e Peru) (Feichtenberger, 1996). No Brasil, a fase teleomórfica ou sexual já foi assinalada nos Estados do Rio de Janeiro (Robbs et al., 1985) e de São Paulo (Goes \& Feichtenberger, 1993).

Na África do Sul, o primeiro relato da Mancha Preta dos Citros ocorreu em 1929, próximo a Pietermaritzburg em laranjeira 'Natal' (Doidge, 1929, citado por Kellerman \& Kotzé, 1977). Em 1952, Wagner (citado por Kellerman \& Kotzé, 1977) relata as grandes perdas ocorridas em laranja 'Natal' no leste de Transvaal Lowveld e norte de Transvaal, e em limoeiros, no oeste de Transvaal.

A Mancha Preta dos Citros é uma importante doença em Taiwan, afetando algumas espécies, incluindo 'Ponkan' ( $C$. reticulala Blanco), 'Tankan' (C. tankan Hayata) e laranjeiras doces (C. sinensis) (Tsai, 1981). A forma imperfeita do fungo foi reportada em 1911 por Sawada, e peritécios maduros de $G$. citricarpa foram primeiramente observados em folhas caidas de citros por Liu (1966), citado por Tsai (1981).

No Brasil, os primeiros sintomas da Mancha Preta dos Citros foram observados em frutos de laranjeira 'Pêra' e 'Seleta', no mercado municipal de Piracicaba (SP), em agosto de 1937 (Averna-Saccá, 1940). Entretanto, há dúvidas quanto à identificação, mas Goes (1998) admite a hipótese de que a erradicação de milhões de plantas pelo vírus da tristeza dos citros, na década de 40 , possa também ter culminado com a erradicação temporária da Mancha Preta em São Paulo. No início da década de oitenta a doença foi novamente descrita, porém no Estado do Rio de Janeiro, municípios de São Gonçalo e 
Itaborai, causando prejuizos significativos (Robbs et al., 1980). Nos fins da década de oitenta, surgiu de forma epidêmica na região citricola do Vale do Caí, no Rio grande do Sul (Robbs \& Bittencourt, 1995). Em 1993, foi novamente assinalada no Estado de São Paulo, infectando plantas de limoeiros verdadeiros e laranjeiras doces de maturação tardia, nos municipios de Conchal e Engenheiro Coelho (Goes \& Feichtenberger, 1993).

Segundo Kotzé (1988), a epidemiologia da Mancha Preta dos Citros é influenciada pela disponibilidade de inóculo, condições climáticas requeridas para infecção, estágio de desenvolvimento das plantas citricas e idade do fruto em relação à suscetibilidade à infecção e eventual desenvolvimento dos sintomas. O período crítico para a infecção inicia-se após a queda das pétalas e se estende até $4-5$ meses de desenvolvimento dos frutos.

O patógeno possui duas fontes de inóculo responsáveis pelas infecções. A primeira é constituída por picnidiósporos formados nas lesões de frutos temporãos ou tardios afetados e não colhidos (Robbs, 1990). Os esporos são transportados por gotículas de orvalho ou de chuvas e levados para a superficie de folhas ou frutos novos. A segunda é constituída pelos ascósporos expulsos dos peritécios formados em folhas caídas ao solo e que infectam frutos e folhas novas, principalmente pela ação dos ventos. Os esporos sexuais e assexuais viáveis, quando caídos na superficie molhada dos frutos, podem germinar, dando origem a um apressório, seguindo-se de uma hifa infectiva que penetra na cutícula e vai transformar-se em uma pequena massa de micélio dormente no interior dos tecidos da casca (Robbs, 1990; Rossetti et al., 1993). Observa-se então um longo período de dormência ou latência, que pode atingir de três a doze meses após a antese, dependendo da variedade, temperatura e condições da planta (McOnie, 1967).

Segundo Klotz (1973), o fungo infecta somente tecido jovem e permanece dormente até a temperatura chegar a $21{ }^{\circ} \mathrm{C}_{3}$ e os ascósporos são a principal fonte de inóculo, mas não são encontrados em frutos, somente em folhas em decomposição. Algumas vezes os sintomas se desenvolvem após a colheita dos frutos, aparecendo durante o transporte e podendo causar perdas consideráveis.

A manifestação dos sintomas e a ocorrência de epidemias são determinadas por vários fatores, sendo os mais importantes: a exposição dos frutos à maior luminosidade; 
temperaturas oscilando entre 20 e $24^{\circ} \mathrm{C}$ durante a maturação; e nos frutos originados de árvores estressadas (Kotzé, 1981).

De acordo com Kotzé (1981) existem quatro tipos principais de lesões em frutos: a) As lesões mais típicas da doença são as manchas marrons ou duras, caracterizadas por apresentarem um halo amarelado em frutos verdes, e um halo esverdeado em frutos maduros, ocorrendo no inicio da maturação; b) As manchas sardentas apresentam lesões levemente deprimidas e avermelhadas, atingindo os frutos que já passaram pela coloração verde para a amarelada ou laranja; c) Já as manchas negras ou virulentas podem surgir no campo, no transporte e armazenamento dos frutos, formando grandes lesões deprimidas originadas das duas lesões anteriores; d) 0 quarto tipo de lesão conhecido como pinta preta ou falsa melanose, é caracterizado por minúsculas e numerosas pintas negras semelhantes às de melanose.

As folhas também podem apresentar sintomas da doença, e quando presentes, são representadas por pequenas manchas necróticas com centro acinzentado, rodeado por um anel marrom-escuro e um halo amarelado. As manchas em folhas aparecem com maior freqüência em limoeiros que em outras variedades (Kotzé, 1988).

Com exceção da laranjeira 'Azeda' (Citrus aurantium L.) e seus hibridos, quase todas as espécies e variedades de citros são suscetiveis à doença, especialmente limoeiros verdadeiros e laranjeiras de maturação tardia (Kotzé, 1981). Frutos severamente afetados podem cair precocemente (Kotzé, 1988). No Estado do Rio de Janeiro, os prejuizos mais significativos têm sido verificados em laranjeiras 'Folha Murcha', 'Valência' e 'Natal' e em mexeriqueira do 'Rio' (Citrus deliciosa Tenore). A MPC tem sido responsável por grandes prejuizos em várias regiões produtoras de citros no mundo. Perdas superiores a $80 \%$ já foram verificadas na Austrália e na África do Sul (Klotz, 1978).

As lesões produzidas se restringem à casca do fruto, prejudicando a comercialização in natura. Em análises feitas no Brasil, o conteúdo de ácidos é ligeiramente maior nos frutos infectados, tornando-os menos adocicados (AguilarVildoso, comunicação pessoal), e os teores de sólidos solúveis totais sofrem alterações desprezíveis. Entretanto, na África do Sul, é citado que os frutos possuem maiores teores 
de sólidos solúveis (Goes, 1998). Os frutos destinados ao mercado de fruta fresca necessitam ser mantidos em temperaturas abaixo de $20^{\circ} \mathrm{C}$ após a colheita para inibir o desenvolvimento pós-colheita da Mancha Preta (Kotzé, 1988).

\subsection{Resistência de plantas a patógenos}

A doença é o produto da interação entre o hospedeiro e o patógeno. Os niveis de doença nas plantas são variáveis devido a alterações na frequêencia da população do patógeno virulento ao nivel de resistência do hospedeiro ou a modificaçães do ambiente. A planta não pode ser considerada resistente com base no seu desempenho em condições de baixo nível de doença. Os termos resistência e suscetibilidade são arbitrários e necessitam de uma padronização para os diferentes patossistemas (Prabhu \& Morais, 1993).

A resistência de um hospedeiro, dentro do contexto da fisiologia do parasitismo, pode ser definida como a capacidade da planta em atrasar ou evitar a entrada e a subsequente atividade de um patógeno em seus tecidos e é caracterizada por sua natureza dinâmica e coordenada, onde a efetividade depende da expressão dos seus mecanismos em uma seqüència lógica, após o contato do patógeno com o hospedeiro em potencial (Pascholati \& Leite, 1995).

Segundo Vanderplank (1963), a resistência de plantas a doenças pode ser do tipo vertical, onde as cultivares apresentam resistência a uma ou poucas raças fisiológicas do patógeno, é pouco estável e conferida por genes maiores. Já a resistência horizontal, é conferida por genes menores, sendo considerada de maior estabilidade, onde as cultivares apresentam resistência uniforme contra todas as raças do fungo.

As plantas se defendem dos agentes fitopatogênicos através de mecanismos ou fatores de resistência, que podem ser pré-formados, incluindo aqueles já presentes nas plantas antes do contato com os patógenos, e pós-formados, que mostram-se ausentes ou presentes em baixos níveis antes da infecção, sendo produzidos ou ativados em resposta à presença dos patógenos. Estes fatores de resistência podem ser divididos em estruturais, que atuam como barreiras fisicas, impedindo a entrada do patógeno e a 
colonização dos tecidos, e em bioquímicos, que são reações que ocorrem nas células do hospedeiro, produzindo substâncias que são tóxicas ao patógeno ou criam condições adversas para o crescimento do mesmo no interior da planta (Pascholati \& Leite, 1995). Em doenças fúngicas vasculares, os fatores estruturais induzidos são mais freqüentes que aqueles pré-formados (Resende, 1996).

O grau de envolvimento dos fatores estruturais e bioquímicos, pré- ou pósformados, nas respostas de resistência varia de acordo com a interação patógenohospedeiro e, numa mesma interação, em função da idade da planta, do órgão ou tecido afetado, do estado nutricional e das demais condições ambientais (Pascholati \& Leite, 1994; 1995).

A primeira resposta da planta à invasão fúngica provém da formação de uma espécie de "cápsula" ao redor da ponta da hifa penetrante, através da invaginação e espessamento de paredes primárias em células epidérmicas (Agrios, 1988). Tal barreira protetiva é chamada de bainha ou tubo lignífero, sendo resultado da deposição de material celulósico e de lignina na superficie interna da referida parede celular, impedindo o processo de penetração da hifa no interior do citoplasma (Pascholati \& Leite, 1995).

Em citros, o mofo verde é uma doença importante em pós-colheita, sendo causada pelo fungo Penicillium digitatum Sacc., capaz de penetrar no fruto apenas através de injúrias na casca (Brown, 1973). Ferimentos envolvendo apenas o exocarpo de laranjas possuem a capacidade de cura, tornando-se resistentes à penetração de $P$. digitatum, se as condições de altas temperaturas e umidades relativas forem mantidas após a injúria. As células curadas do exocarpo acumulam substâncias fenólicas e lignina até 30 horas após a injúria, sendo a parede celular menos suscetível à degradação por exo-PG do $P$. digitatum (Brown \& Barmore, 1983). Bonnas et al. (1995) relataram que a injúria mecânica estimula a atividade da fenilalanina amônia - liase (PAL), enzima chave no processo de lignificação, tendo um aumento de seis vezes na sua atividade, após 96 horas de cura de ferimento. Este aumento na atividade da PAL está associado ao acúmulo de substâncias fenólicas, observado nas regiões adjacentes ao ferimento. A alta umidade relativa também teve uma grande influência no processo de cura, evitando a 
dessecação do local injuriado e permitindo a intensificação da atividade metabólica nas regiões vizinhas à área danificada.

Baudoin \& Eckert (1985) confirmaram que a deposição de substâncias lignificantes ao redor de ferimentos não-inoculados no albedo de frutos de limões foi desprezivel, enquanto que ao redor de ferimentos inoculados com Geotrichum candidum, estas substâncias foram significativamente estimuladas. Ainda segundo os mesmos autores, um aumento na concentração de esporos como fonte de inóculo, também aumentou a produção de lignina ao redor da inoculação.

\subsection{Interação planta $x$ patógeno}

Atualmente, a seleção de novos cultivares, principalmente por propagação vegetativa, não vem sendo determinado apenas, pelo genótipo das plantas, mas também, pelo genótipo dos microrganismos associados, que aumentam a sua capacidade de adaptação, como a maior resistência a pragas e doenças.

A graminea Festuca arundinacea, utilizada como pastagem para ovelhas, na Nova Zelândia, vem sendo utilizada para selecionar sementes apomíticas com o fungo endofitico, Acremonium coerophialum, o qual é selecionado para não produzir alcalóides tóxicos aos animais. Esses isolados possuem a capacidade de aumentar a resistência das plantas a insetos como Listronotus bonariensis (Curculionidae) (Siegel et al., 1987).

Alguns endófitos clavicipitáceos de gramíneas produzem determinados compostos biologicamente ativos tanto in vivo como in vitro, sendo estes provavelmente os responsáveis pelos efeitos nocivos em animais herbívoros. Estes alcalóides produzidos pelos endófitos são geralmente referidos como capazes de conferir maior defesa ao seu hospedeiro (Clay, 1989). Os endófitos, além de aumentar o desempenho da planta e protegê-las contra o ataque de insetos e herbivoros, podem proporcionar às plantas hospedeiras um antagonismo contra parasitas patogênicos e saprófitas, decrescendo a senescência da planta (Carroll, 1988). 
Nos citros, o uso de estirpes fracas do vírus da tristeza permitiu que a laranjeira 'Pêra' continuasse como a principal variedade cítrica cultivada, por meio da premunização das plantas matrizes. Provavelmente, muitos dos clones sejam diferentes apenas pela estirpe do virus associado a eles, afetando o vigor, a produtividade e outras características agronômicas. Rossetti et al. (1975), em experimento de 13 seleções de 'Pêra' com diferentes variantes do virus da tristeza, em relação à gomose de Phytophthora, concluiram que as plantas não mostraram sinais de deperecimento, não havendo influência do grau de infecção da tristeza no desenvolvimento de $P$. citrophthora no tronco, provavelmente porque as plantas estavam com 4-5 anos de idade.

Alguns fatores como queda de folhas (tolerância à seca), iluminação da planta (enfolhamento) e mudança de cor dos frutos (maturação), são importantes caracteristicas para a epidemiologia da Mancha Preta dos Citros. Como há diferenças entre os clones de laranjeira 'Pêra', no que se refere à época de maturação dos frutos, ao vigor, a maior ou menor resistência ao estresse hidrico, à produtividade, etc, tais fatores podem ser responsáveis pela deteç̧ão de resistência horizontal ou parcial em níveis que sejam de importância econômica para a citricultura. 


\section{MATERIAL E MÉTODOS}

\subsection{Local}

A área experimental, onde foi desenvolvido este trabalho, está localizada no Centro de Citricultura 'Sylvio Moreira' (CCSM) do Instituto Agronômico de Campinas (IAC), em Cordeirópolis, SP. O solo da área é um Latossolo vermelho escuro distrófico, e o clima da região é do tipo Cwa. Os ensaios de laboratório foram realizados na Clinica Fitopatológica de Citros do CCSM-IAC.

\subsection{Clones de laranjeira 'Pêra'}

Foram estudadas 15 seleções de laranjeira doce, Citrus sinensis (L.) Osbeck. As plantas estavam distribuídas estatisticamente em blocos inteiramente casualizados com seis repetições e uma planta por parcela, em espaçamento de $7 \times 5$ metros, tendo como porta-enxerto o limoeiro 'Cravo', Citrus limonia Osbeck. A área experimental foi conduzida sem irrigação, sendo que as plantas se encontravam nos anos agrícolas de 1999 e 2000 e permaneceram expostas à livre infecção por G. citricarpa.

As plantas fazem parte de um experimento, instalado em dezembro de 1980, composto de clones de laranjeira 'Pêra' e outras variedades com características morfológicas e/ou agronômicas semelhantes à 'Pêra'.

A maioria dos clones de laranjeira 'Pêra' foi coletada no interior do Estado de São Paulo, na década de 1970. A seguir, são indicados os dez clones de laranjeira 'Pêra' e as cinco variedades afins e suas origens, de acordo com Domingues (1998): 
1-'Pêra' Bianchi (Fazenda São Judas Tadeu, de Alfeu Bianchi, Bebedouro; abril de 1970);

2-'Pêra' Dibbern C.V. (Sítio de Benedito Luis Dibbern; setembro de 1971);

3-'Pêra' EEL ('Pêra' selecionada de pé franco no IAC);

4-'Pêra' GS 2000 (Chácara de Guilherme Spanhol, Cascalho; janeiro de 1975);

5-'Pêra' Olímpia 15161 (Olímpia, SP; fevereiro de 1976);

6-'Pêra' Premunizada 1212 (clone pré-imunizado com estirpe fraca do vírus da tristeza dos citros, no IAC);

7-'Pêra' Premunizada 1743/82 (clone pré-imunizado com estirpe fraca do vírus da tristeza dos citros, no IAC);

8-'Pêra' R. Gullo 1569/244 (Fazenda Lagoa Bonita, de Roberto Gullo; abril de 1978);

9-'Pêra' R. Gullo 1570/246 (Fazenda Lagoa Bonita, de Roberto Gullo; abril de 1978);

10-'Pêra' Vimusa (Fazenda Macaúba, Santa Adélia, SP; março de 1979);

11-Corsa Tardia (Banco Ativo de Germoplasma/BAG-citros do CCSM/AC);

12-Lamb's Summer (BAG-citros do CCSM/IAC);

13-Ovale 968 (BAG-citros do CCSM/IAC);

14-Ovale San Lio 969 (BAG-citros do CCSM/IAC);

15-Redonda C.N. (BAG-citros do CCSM//AC).

\subsection{Isolado de Guignardia citricarpa}

O fungo (Isolado IAC-41/99) utilizado para a instalação dos experimentos in vitro, foi isolado em 1999, pelo pesquisador Carlos Ivan Aguilar-Vildoso, de folhas assintomáticas de tangerineira 'Ponkan' (C. reticulata Blanco). 


\subsection{Meios de cultura}

\subsubsection{Meio ágar-água $(3 \% \mathrm{p} / v)$}

O meio ágar-água foi preparado de acordo com Silva \& Aguilar-Vildoso (2000) utilizando-se $30 \mathrm{~g}$ de ágar e $1000 \mathrm{ml}$ de água. O ágar e a água foram autoclavados por 20 minutos a $120^{\circ} \mathrm{C} \mathrm{e} 1$ atm.

Este meio de cultura foi utilizado no experimento de indução à produção de corpos de frutificação de G. citricarpa em folhas cítricas autoclavadas.

\subsubsection{Meio cenoura-ágar}

O meio cenoura-ágar foi preparado utilizando-se $200 \mathrm{~g}$ de cenoura, $1000 \mathrm{ml}$ de água destilada e $20 \mathrm{~g}$ de ágar. A cenoura foi triturada no liqüidificador na máxima velocidade por aproximadamente 1 minuto, e em seguida peneirada em malha de 150 mesh. Após a mistura do ágar com o suco da cenoura, o meio foi autoclavado por 20 minutos a $120^{\circ} \mathrm{C}$ e 1 atm.

Este meio foi utilizado para a manutenção das colônias de G. citricarpa.

\subsubsection{Meio cenoura-ágar-glicose}

O meio cenoura-ágar-glicose foi preparado nas proporções de $200 \mathrm{~g}, 20 \mathrm{~g}$ e $180 \mathrm{~g}$ por litro, respectivamente. A cenoura foi triturada no liqüidificador na máxima velocidade por aproximadamente 1 minuto, e em seguida peneirada em malha de 150 mesh. Após a mistura do ágar e da glicose com o suco da cenoura, o meio foi autoclavado por 20 minutos a $120^{\circ} \mathrm{C}$ e 1 atm.

Este meio foi utilizado no experimento de colonização natural das folhas por G. citricarpa, pois funciona como meio semi-seletivo ao fungo em estudo conforme citado por Campos \& Aguilar-Vildoso (2001). 


\subsection{Quantificação e distribuição da incidência e da severidade dos sintomas da Mancha Preta dos Citros}

Para a diferenciação dos clones de laranjeira 'Pêra' quanto à suscetibilidade à Mancha Preta dos Citros, a severidade dos sintomas da doença na superficie da casca dos frutos foi quantificada a partir de uma escala diagramática (Aguilar-Vildoso, 2001). Esta escala de notas variava de ' 0 ' a ' 6 ', ou seja, ' 0 ' quando não há nenhuma lesão na superficie do fruto, e as notas de ' 1 ' a ' 6 ", correspondem respectivamente, às áreas lesionadas de $0,7 \%, 1,4 \%, 2,8 \%, 5,6 \%, 9,2 \%$ e $18,4 \%$. Foram avaliados, ao acaso, 80 frutos planta. As avaliações foram feitas no final de setembro para a safra de $1999 \mathrm{e}$ início de novembro para a safra 2000.

Utilizando-se da escala diagramática, a distribuição da severidade dos sintomas da doença foi avaliada em quatro posições diferentes, de acordo com a distribuição dos frutos na copa das plantas. Foram avaliados 20 frutos em cada posição relacionada abaixo:

a) frutos localizados até 1 metro de altura e aproximadamente a $40 \mathrm{~cm}$ no interior das plantas;

b) frutos localizados entre 1-2 metros de altura e aproximadamente a $40 \mathrm{~cm}$ no interior das plantas;

c) frutos localizados acima de 2 metros de altura, e aproximadamente a $40 \mathrm{~cm}$ no interior das plantas;

d) frutos localizados no interior das plantas, ou seja, a mais de $40 \mathrm{~cm}$ no interior das plantas.

Foram analisados estatisticamente, o indice de severidade dos sintomas (notas de 0 a 6) e a incidência (\% de frutos com lesões) da Mancha Preta dos Citros para as safras de 1999 e 2000. 


\subsection{Capacidade reprodutiva de $G$. citricarpa em folhas autoclavadas in vitro}

Utilizaram-se folhas maduras dos clones descritos no item 3.2 e de duas variedades controle: trifoliateiro Limeira (Poncinus trifoliata Rafinesque) e limoeiro 'Eureka' (Citrus limon Burmman), variedades resistente e suscetível, respectivamente, as quais eram mantidas no Banco de Germoplasma do CCSM-IAC. Optou-se pela escolha destas duas variedades como controle, pois no campo, os limoeiros verdadeiros apresentam maior incidência e severidade da doença (Kotzé, 1981), portanto, muito suscetiveis, e o trifoliateiro como variedade resistente, pois é assintomático.

As colônias de G. citricarpa (isolado IAC-41/99), conforme item 3.3, foram utilizadas, pois, em experimentos anteriores, este isolado foi o que apresentou maior capacidade de diferenciação entre variedades, e maior correlação com as diferenças de suscetibilidade encontradas em condições de campo (Silva \& Aguilar-Vildoso, 2000).

De acordo com a metodologia utilizada por Silva \& Aguilar-Vildoso (2000), foram coletadas folhas maduras das variedades, as quais foram lavadas em água corrente e cortadas em fragmentos circulares de $0,8 \mathrm{~cm}$ de diâmetro. Posteriormente, foram autoclavados (20 minutos a $120^{\circ} \mathrm{C}$ ) 50 fragmentos foliares em frascos contendo $100 \mathrm{ml}$ de água destilada.

Foram acondicionados cinco discos foliares de cada variedade em placas de Petri, contendo o meio ágar-água $(3 \% \mathrm{p} / \mathrm{v})$. Ao lado de cada disco foliar foram plaqueados pequenos fragmentos da extremidade das colônias de G. citricarpa, desenvolvidos em meio cenoura-ágar. As placas foram vedadas e incubadas em câmara de crescimento a $25^{\circ} \mathrm{C}$, no escuro.

O delineamento estatístico foi inteiramente casualizado, composto por dezessete tratamentos, com 4 repetições. Cada avaliação nas parcelas experimentais foi representada pela média de três fragmentos foliares, cada um com três locais aleatórios de observação.

Após 28 dias, realizou-se a contagem do número de estruturas reprodutivas produzidas por $G$. citricarpa nos fragmentos foliares, com o auxílio de um microscópio estereoscópio, no aumento de $5 x$ e objetiva de $20 x$. Em cada campo de observação 
foram quantificados os tipos de estruturas produzidas pelo fungo, que foram divididas em corpos de frutificação sem liberação dos esporos, ou seja, estruturas imaturas, e número total de corpos de frutificação (estruturas imaturas mais os picnídios liberando os picnidiósporos).

\subsection{Indução de estruturas reprodutivas de $G$. citricarpa em folhas destacadas}

Foram coletadas 12 folhas maduras (cor verde-escuro), aproximadamente a 1 metro de altura, ao redor da planta, em 6 plantas por clone de laranjeira 'Pêra'. As folhas foram lavadas em água corrente para se retirar a poeira e a fumagina, que porventura estariam presentes, deixando-as limpas. Após a lavagem, as folhas foram acomodadas em bandejas plásticas, onde foram envelhecidas, sendo que diariamente sofreram processo de secagem - umedecimento, para induzir a produção de corpos de frutificação de G. citricarpa (Kotzé, 1981), com o inóculo que naturalmente colonizou as folhas, mas se encontrava na forma latente. Este processo consistiu em pulverizar as folhas com água (umedecimento), e expô-las ao sol para sofrerem o processo de secagem. Foi quantificada a incidência, ou seja, a porcentagem de folhas que apresentavam estruturas reprodutivas do fungo.

Realizou-se também, a quantificação da área da folha, ocupada pelas estruturas reprodutivas de G. citricarpa. Esta parte do experimento consistiu em desenhar as folhas em papel vegetal, delimitando a área ocupada pelos corpos de frutificação. Ambas as áreas (sadia e ocupada pelas estruturas), foram pintadas em cores diferentes. Cada folha foi digitalizada, e em seguida transferida para um programa de computador SIARCS 3.0 (Sistema Integrado para Análise de Raízes e Cobertura do Solo, versão 3.0), desenvolvido pela EMBRAPA-CNPDIA, o qual reconhece as áreas pelas cores distintas, dando o valor total da área das folhas e da área ocupada pelos corpos de frutificação, podendo-se, assim, calcular a porcentagem da área da folha ocupada pelas estruturas reprodutivas do fungo. 


\subsection{Colonização natural das folhas por $G$. citricarpa}

A densidade de colonização das folhas foi quantificada nos clones de laranjeira 'Pêra' descritos no item 3.2. As plantas do experimento permaneceram expostas à livre infecção por G. citricarpa. O meio de cultura utilizado no experimento foi o cenouraágar-glicose, descrito no item 3.4.3.

Foram coletadas dez folhas maduras de cada clone, aproximadamente a 1 metro de altura, ao redor da planta, as quais foram limpas em água corrente. Em seguida, foi feita a imersão em álcool, por 1 minuto, e hipoclorito de sódio, por 3 minutos para a desinfecção superficial das folhas. Após a desinfecção, as folhas foram cortadas em fragmentos de $0,36 \mathrm{~cm}^{2} \mathrm{em}$ média (adaptado de Glienke, 1995), e em seguida foram acondicionados 10 fragmentos ( 5 por folha) por placa de Petri, contendo meio cenouraágar-glicose.

As placas foram mantidas em câmara de crescimento a $25^{\circ} \mathrm{C}$, no escuro. Após cinco dias, as placas foram avaliadas, contando-se o número de colônias de $G$. citricarpa que surgiram dos fragmentos de cada folha, em cada placa de Petri.

Obtiveram-se, então, a incidência e a densidade de colonização de $G$. citricarpa por $\mathrm{cm}^{2}$ de área foliar, para cada clone de laranjeira 'Pêra'. A incidência corresponde ao número de fragmentos, nos quais foi possivel avaliar a presença de colônias do fungo, dada em porcentagem. A densidade de isolamento consistiu do número médio de colônias de $G$. citricarpa, isoladas por $\mathrm{cm}^{2}$ de área foliar.

\subsection{Produção de frutos}

A produção foi obtida por meio de uma balança, marca Filizola. Os frutos foram coletados, colocados em sacos e pesados. Foi realizada a análise estatística dos dados. 


\subsection{Queda de folhas e frutos}

Para a realização da contagem do número de folhas caídas, foram colocadas duas telas de $1 \mathrm{~cm}^{2}$ de malha, com $1 \mathrm{~m}^{2}$ de tamanho, sob a copa de cada planta, de modo que não atrapalhasse os tratos culturais do pomar. As avaliações foram realizadas quinzenalmente, de agosto de 1999 a dezembro de 2000 , contado-se o número de folhas caídas sobre cada tela.

Avaliou-se a severidade da doença para todos os frutos caidos em três regiões, ou seja, na base, no ápice e na lateral do fruto. As avaliações foram realizadas quinzenalmente, de julho a setembro, para as safras de 1999 e 2000.

\subsection{Desenvolvimento vegetativo das plantas}

Para se estimar o porte da planta, ou seja, o volume da copa de cada planta, foram feitas medições, com o auxílio de uma régua graduada, da altura e do diâmetro da copa. As medições de diâmetro foram feitas em cada planta, na linha, e na entre linha.

O volume da copa foi estimado pela fórmula citada por Figueiredo (1976):

$$
\mathrm{V}=2 / 3 \pi \mathrm{R}^{2} \mathrm{H}
$$

onde,

$-\mathrm{V}=$ volume da copa;

$-\mathrm{R}=$ raio médio;

- $\mathrm{H}=$ altura da planta.

A altura e o volume da copa das plantas foram analisados estatisticamente e correlacionados com a severidade dos sintomas da doença. 


\subsection{Caracteristicas externas dos frutos}

A avaliação das características externas dos frutos foi realizada em amostras de 10 frutos maduros de cada clone para os seguintes caracteres: severidade da Mancha Preta dos Citros; coloração da casca (Figura 1); e morfologia (altura; largura; peso; formato, forma do ápice e da base; ângulo e achatamento da região basal; espessura da casca, do epicarpo e do mesocarpo). Para a determinação do ângulo e achatamento da região basal, espessura da casca, do epicarpo e do mesocarpo, utilizaram-se amostras de 4 frutos.

\subsubsection{Severidade da Mancha Preta dos Citros na amostra de frutos}

Utilizando-se da mesma escala diagramática descrita no item 3.5, foi realizada a avaliação da severidade da Mancha Preta dos Citros em cada amostra coletada para análise de qualidade de suco. Posteriormente, todos os dados de características internas e externas dos frutos foram correlacionados com a severidade da doença na amostra de frutos. Foi feita também, a análise estatística dos dados de severidade da amostra.

\subsubsection{Coloração da casca dos frutos}

A avaliação da coloração da casca foi feita através da escala de cores representada na Figura 1. Determinaram-se notas de 1 a 6 , sendo a nota 1 atribuída ao fruto mais verde, e as notas subsequentes foram dadas conforme os frutos foram se tornando mais alaranjados. Calculou-se a análise estatística dos dados e a correlação entre a severidade da doença e a coloração da casca dos frutos da amostra para análise de suco. 


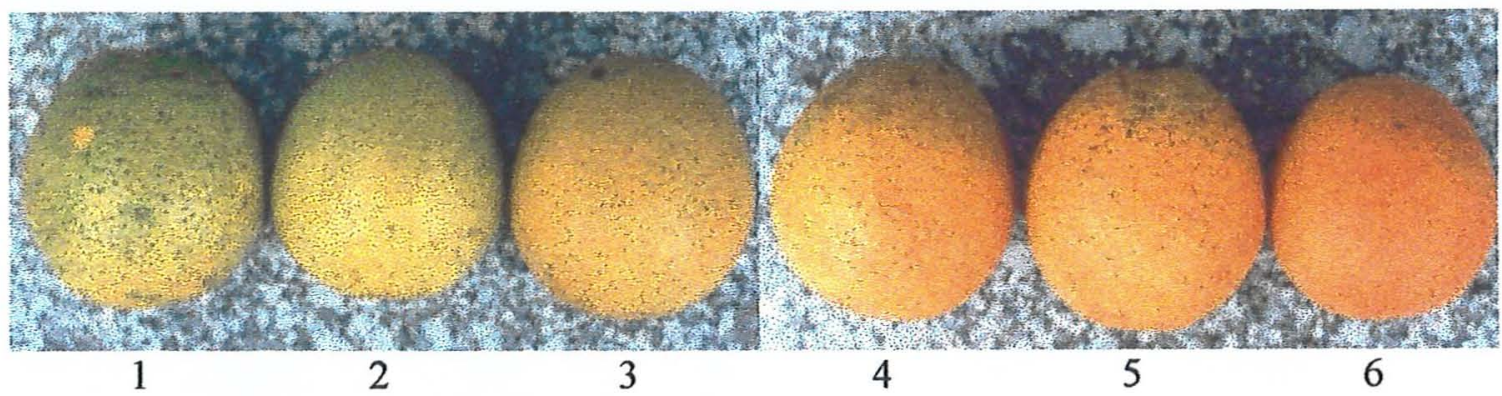

Figura 1 - Escala de cores para os frutos.

\subsubsection{Morfologia dos frutos}

\subsubsection{Altura e largura dos frutos}

As determinações de altura e largura dos frutos foram feitas por leitura direta em cada fruto da amostra, com auxílio de escala graduada em centímetros, e a partir desses valores, foi calculada a relação entre a altura e o diâmetro $(\mathrm{A} / \mathrm{L})$ dos frutos. Foi feita a análise estatística dos dados.

\subsubsection{Massa dos frutos}

A massa total dos frutos de cada amostra foi obtida, de uma só vez, através de uma balança, marca Filizola. Este parâmetro serve como base de cálculo para rendimento de suco. Foi realizada a análise estatística dos dados.

\subsubsection{Formato, forma da base e do ápice dos frutos}

Os frutos foram avaliados quanto à sua morfologia apenas no ano de 2000, baseando-se no Descriptiors for citrus (IBPGR, 1999).

Quanto ao formato, os frutos foram classificados como: esferóide, elipsóide, periforme, oblíquo, achatado, avóide-oblíquo e ovóide. 
Quanto à forma da base, os frutos foram classificados em: mamiforme, angular, convexo, truncado e depressivo.

Já para a forma do ápice, os frutos foram classificados em: com pescoço, convexo, truncado, côncavo, côncavo com colarinho e colarinho com pescoço.

\subsubsection{4 Ângulo e achatamento da região basal do fruto}

Para a determinação do ângulo e do achatamento da região basal dos frutos, estes foram cortados ao meio, no sentido longitudinal, e em seguida desenhados em papel manteiga.

$O$ ângulo foi determinado, traçando-se uma tangente pelo ombro do fruto (Figura 2). $\mathrm{O}$ valor das tangentes foi encontrado pelas regras do triângulo retângulo, através do quociente do Cateto oposto sobre Cateto adjacente. $O$ valor do ângulo foi calculado pelo arco tangente.

$\mathrm{O}$ achatamento foi representado pela medida da região plana de inserção do pedúnculo do fruto (Figura 2).

As determinaçães do ângulo e do achatamento foram feitas em quatro frutos de cada parcela, com seis repetições. Foram calculadas as análises estatísticas e a correlação do ângulo e do achatamento com a severidade dos sintomas da doença. 


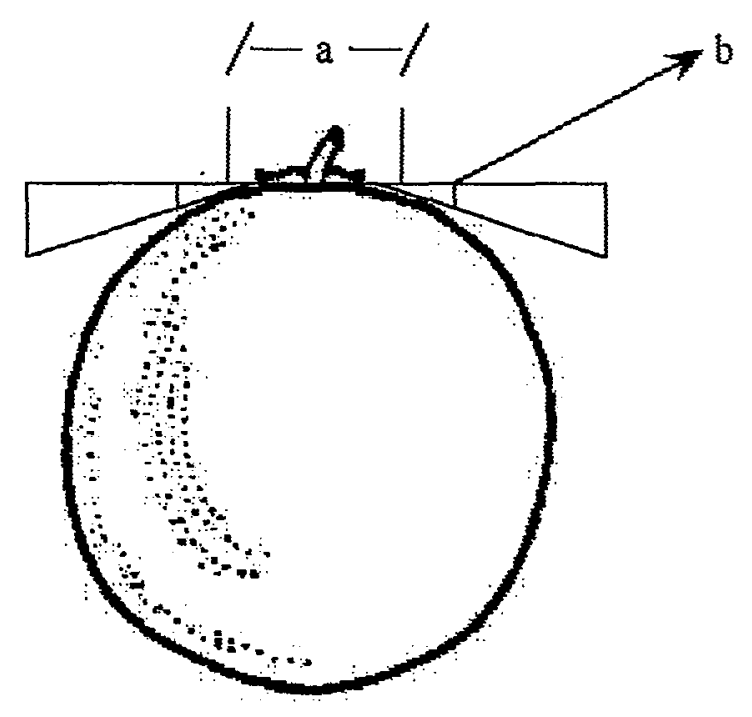

Figura 2 - Representação do achatamento (a) e do ângulo do ombro (b) dos frutos.

\subsubsection{Espessura da casca, do mesocarpo e do epicarpo dos frutos}

Com o auxilio de um paquímetro, foram medidas a espessura total da casca, compreendida pelo epicarpo e mesocarpo, e do epicarpo, que é a porção externa da casca onde se localizam as vesículas de óleo. Pela diferença entre a espessura total da casca e a espessura do epicarpo, obteve-se a espessura do mesocarpo, que é o albedo dos frutos.

Foram coletados quatro frutos por clone de laranjeira 'Pêra', com seis repetições. Em cada fruto, foram feitas três medições, sendo: uma na parte superior do fruto, próximo ao pedúnculo, outra na parte média do fruto, e uma terceira na parte basal do fruto. Estas três medições foram analisadas separadamente pelo delineamento em blocos inteiramente casualizados e correlacionados com a severidade dos sintomas da doença. 


\subsection{Características internas dos frutos}

Todas as análises de qualidade de suco foram realizadas no Laboratório de Qualidade do CCSM. Foram analisadas as seguintes características internas dos frutos: rendimento de suco; sólidos solúveis; acidez total; relação sólidos solúveis:acidez (Ratio); e, índice tecnológico ( $\mathrm{kg}$ sólidos solúveis por caixa), para as safras de $1999 \mathrm{e}$ 2000 .

\subsubsection{Rendimento de suco}

O rendimento de suco foi determinado após esmagamento dos frutos da amostra em extratora OIC modelo OTTO 1800 (Filtro: diâmetro interno $=26,11 \mathrm{~mm}$; comprimento $=265 \mathrm{~mm}$; furos de diâmetro $=0,6 \mathrm{~mm}$; área de vazão $=20 \%$ ), e calculado através da relação peso do suco/peso do fruto e expresso em porcentagem. Os dados foram analisados estatisticamente e correlacionados com a severidade da doença.

\subsubsection{Sólidos solúveis $\left({ }^{0}\right.$ Brix $)$}

O teor de sólidos solúveis foi determinado por leitura direta no refratômetro de mesa B \& S, modelo RFM 330, correlacionando medidas de índices de refração da luz entre dois meios e os teores de açúcar da solução, dado em ${ }^{\circ}$ Brix. Os dados foram corrigidos pela temperatura $\left({ }^{\circ} \mathrm{C}\right)$ e pela acidez do suco.

$\mathrm{O}^{\circ} \mathrm{Brix}$ mede o teor de açúcares totais presentes no suco, na relação de gramas de açúcares totais $/ 100 \mathrm{~mL}$ de suco, sendo sacarose, frutose e glicose os principais constituintes do suco cítrico.

Os dados foram analisados estatisticamente e correlacionados com a severidade da doença na amostra para análise de suco. 


\subsubsection{Acidez total}

A acidez foi obtida por titulação de uma alíquota de $25 \mathrm{ml}$ de suco, até pH 8,2 , utilizando-se uma solução de hidróxido de sódio $(\mathrm{NaOH})$ de normalidade de $0,3125 \mathrm{~N}$, e fenolftaleina como indicadora, calculando-se com base em volume.

Os dados foram analisados estatisticamente e correlacionados com a severidade da doença na amostra para análise de suco.

\subsubsection{Relação sólidos solúveis: acidez (Ratio)}

O ratio foi calculado através da relação sólidos solúveis:acidez, considerandose o valor da acidez igual a 1 . Essa relação indica o estado de maturação dos frutos cítricos.

Os dados foram analisados estatisticamente e correlacionados com a severidade da doença na amostra para análise de suco.

\subsection{5 Índice tecnológico (kg sólidos solúveis por caixa)}

O índice tecnológico foi obtido pela equação descrita por Di Giorgi et al. (1990) e está demostrada abaixo:

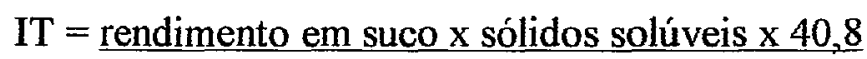

10.000

onde,

- IT = indice tecnológico;

- rendimento em suco = relação peso do suco/peso dos frutos da amostra;

- sólidos solúveis $=$ teor de sólidos solúveis;

$-40,8=$ peso padrão da caixa de colheita de laranja, em $\mathrm{kg}$. 


\subsection{Porcentagem de luz no interior das plantas}

A penetração da luz no interior das plantas, foi mensurada com o auxílio de um quantômetro (Q 247447), acoplado a um Data Logger LI-COR, modelo LI-1400, pertencente ao Departamento de Ciências Biológicas da USP/ESALQ. $O$ aparelho mede a radiação fotossinteticamente ativa (PAR), sendo a unidade dada em umoles de fóton $/ \mathrm{m}^{2} / \mathrm{s}$.

Realizaram-se duas medições nas plantas, sendo uma no início de agosto e a outra no inicio de setembro de 2000. A luminosidade foi mensurada alternadamente em quatro pontos, tanto na região externa à planta (RE), como no seu interior (I), obtendo-se por regra de três simples $\left(I^{*} 100 / R E\right)$, a porcentagem de luz no interior das plantas de laranjeira 'Pêra'.

Os dados foram analisados estatisticamente e foi realizada a correlação da porcentagem de luz no interior das plantas com a severidade dos sintomas da doença. 


\section{RESULTADOS E DISCUSSÃO}

\subsection{Quantificação e distribuição da incidência e da severidade dos sintomas da Mancha Preta dos Citros}

Para as condições experimentais, não houve diferenças estatísticas para o indice de severidade dos sintomas e para a incidência da Mancha Preta dos Citros entre os dez clones de laranjeira 'Pêra' e as cinco variedades afins pelo teste de Tukey a $5 \%$ de significância, nas safras de 1999 e 2000 (Tabela 1), respectivamente. A relação incidência - severidade foi alta, com coeficiente de determinação igual a 0,92 e 0,81 para as safras 1999 e 2000, respectivamente (Figuras 3 e 4).

Pode-se observar um aumento em torno de $20 \%$ na incidência e de 0,53 no índice de severidade da doença, de 1999 para 2000. Isto indica que a doença ainda está crescendo no espaço, com o aumento da incidência (aumento no número de frutos doentes), e no tempo, com o aumento da incidência e da severidade. Quando a maioria dos frutos já apresentarem sintomas (incidência elevada), praticamente não haverá mais crescimento espacial. A evolução da doença no tempo será quase que exclusivamente pelo aumento da severidade (Amorim, 1995).

Foi calculada a correlação entre a incidência da doença e frutos para comercialização no mercado interno (Figuras 5 e 6), ressaltando que para exportação, os frutos devem estar livres de lesões da doença, sendo esta uma barreira fitossanitária, principalmente para o mercado Europeu. Foram considerados frutos com notas até $2,3 \mathrm{e}$ 4 da escala diagramática, para os anos de 1999 e 2000, respectivamente. Quanto mais restrita a comercialização de frutos com lesões, menores são as quantidades de frutos para o comércio de fruta fresca. Por exemplo, de acordo com a Figura 5, considerandose que o mercado aceite frutos com nota 2 de severidade, o que equivale a $1,4 \%$ de área 
lesionada, e supondo que um pomar tenha $50 \%$ de incidência da doença, o produtor teria um prejuízo de $20 \%$ da comercialização para o mercado de frutas frescas, podendo comercializar estes frutos apenas com a indústria de suco concentrado. Mas se o mercado aceitasse frutos com nota 3 (2,8\% de área lesionada), as perdas diminuiriam para $5 \%$ e se aceitasse frutos com nota até 4 (5,6\% de área lesionada), as perdas seriam de apenas $2-3 \%$, entretanto, os frutos ficam prejudicados visualmente.

Tabela 1. Índice de severidade (notas de 0 a 6 ) e incidência ( $\%$ de frutos com lesões) da Mancha Preta dos Citros em dez clones de laranjeira 'Pêra' e cinco variedades afins, em Cordeirópolis-SP, safras 1999 e 2000.

\begin{tabular}{lcccc}
\hline Variedades & \multicolumn{2}{c}{ Indice de severidade } & \multicolumn{2}{c}{ Incidência da doença } \\
\hline & 1999 & 2000 & 1999 & 2000 \\
\cline { 2 - 5 } Bianchi & 1,13 & 1,34 & 54,75 & 65,00 \\
Corsa Tardia & 1,30 & 2,07 & 57,71 & 81,25 \\
Dibbern C.V. & 0,94 & 1,51 & 46,04 & 72,50 \\
EEL & 1,32 & 1,81 & 57,50 & 72,08 \\
GS 2000 & 1,12 & 1,92 & 51,33 & 73,75 \\
Lamb's Summer & 1,67 & 1,86 & 68,33 & 76,60 \\
Olimpia 15161 & 1,04 & 1,57 & 49,41 & 71,25 \\
Ovale 968 & 0,93 & 1,70 & 44,81 & 68,33 \\
Ovale San Lio 969 & 1,04 & 1,73 & 45,30 & 68,39 \\
Premunizada 1212 & 1,00 & 1,32 & 50,06 & 66,61 \\
Premunizada 1743/82 & 0,82 & 1,63 & 41,16 & 72,29 \\
R. Gullo 1569/244 & 1,00 & 1,78 & 49,43 & 70,42 \\
R. Gullo 1570/246 & 0,83 & 1,48 & 41,84 & 65,45 \\
Redonda C.N. & 1,30 & 1,16 & 61,46 & 62,71 \\
Vimusa & 0,84 & 1,32 & 45,64 & 65,42 \\
\hline Média & 1,08 & 1,61 & 50,98 & 70,14 \\
\hline C.V. & $11,59 \%$ & $11,35 \%$ & $21,30 \%$ & $11,59 \%$ \\
\hline Os dados de índice de severidade foram transformados pela raiz quadrada, e os dados de incidência pelo \\
arco seno.
\end{tabular}


Pelos resultados de campo apresentados, podemos salientar duas hipóteses para esta não diferenciação entre os clones de laranjeira 'Pêra' e as variedades afins quanto à incidência e ao índice de severidade dos sintomas da MPC nos frutos: 1) realmente os clones de laranjeira 'Pêra' e as variedades afins não diferem entre si quanto à suscetibilidade à doença no campo; 2) esta não diferenciação pode estar relacionada ao erro críptico (Vanderplank, 1963), ou seja, ocorre uma interferência do inóculo de uma parcela sobre a outra, devido à principal fonte de inóculo, os ascósporos, ser disseminada pelo vento a longas distâncias, podendo mascarar a resistência horizontal ou parcial das variedades à doença.

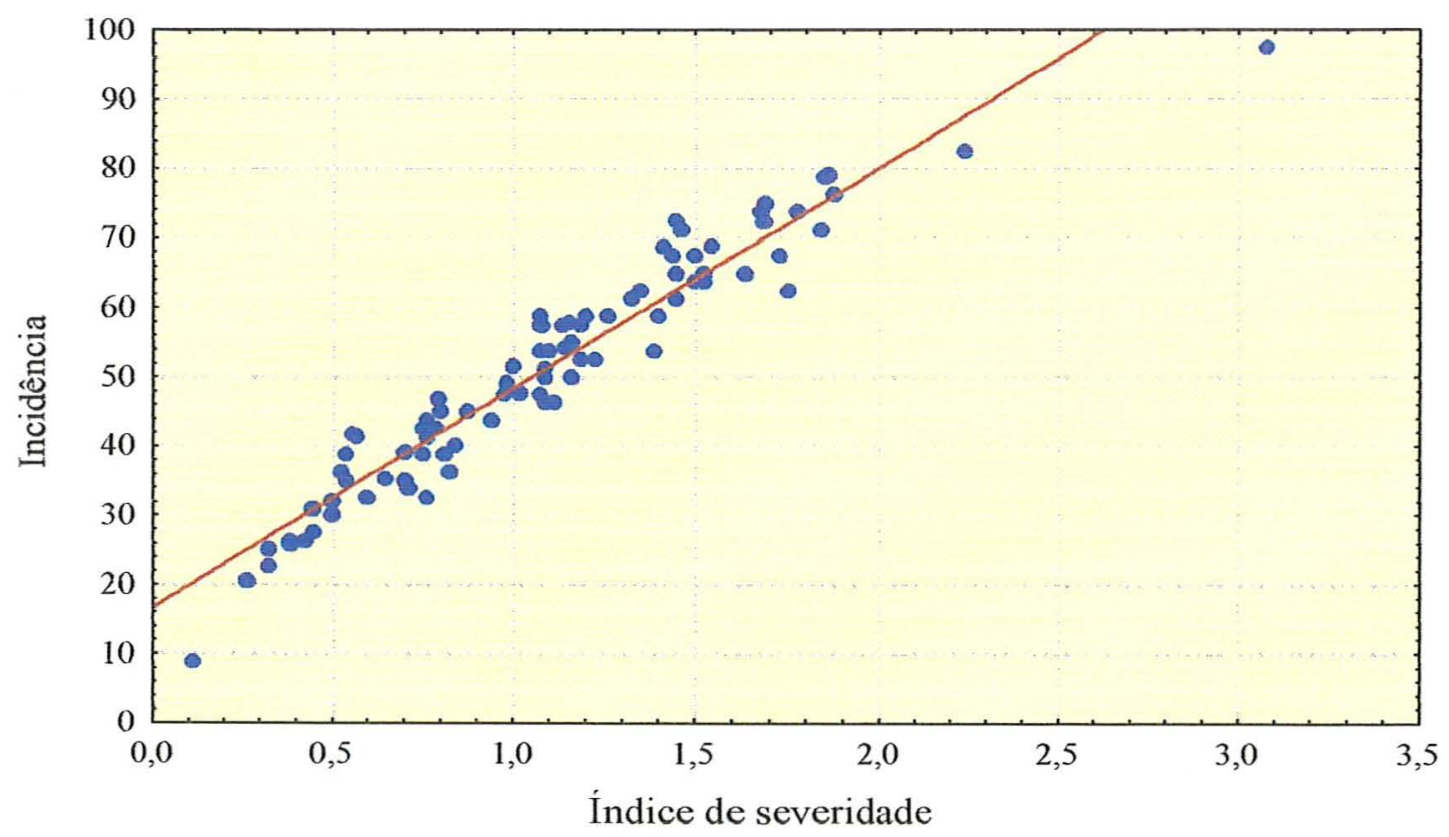

Figura 3 - Relação incidência - severidade da Mancha Preta dos Citros $\left(R^{2}=0,92\right)$ avaliada em dez clones de laranjeira 'Pêra' e cinco variedades afins, em Cordeirópolis-SP, safra 1999. 


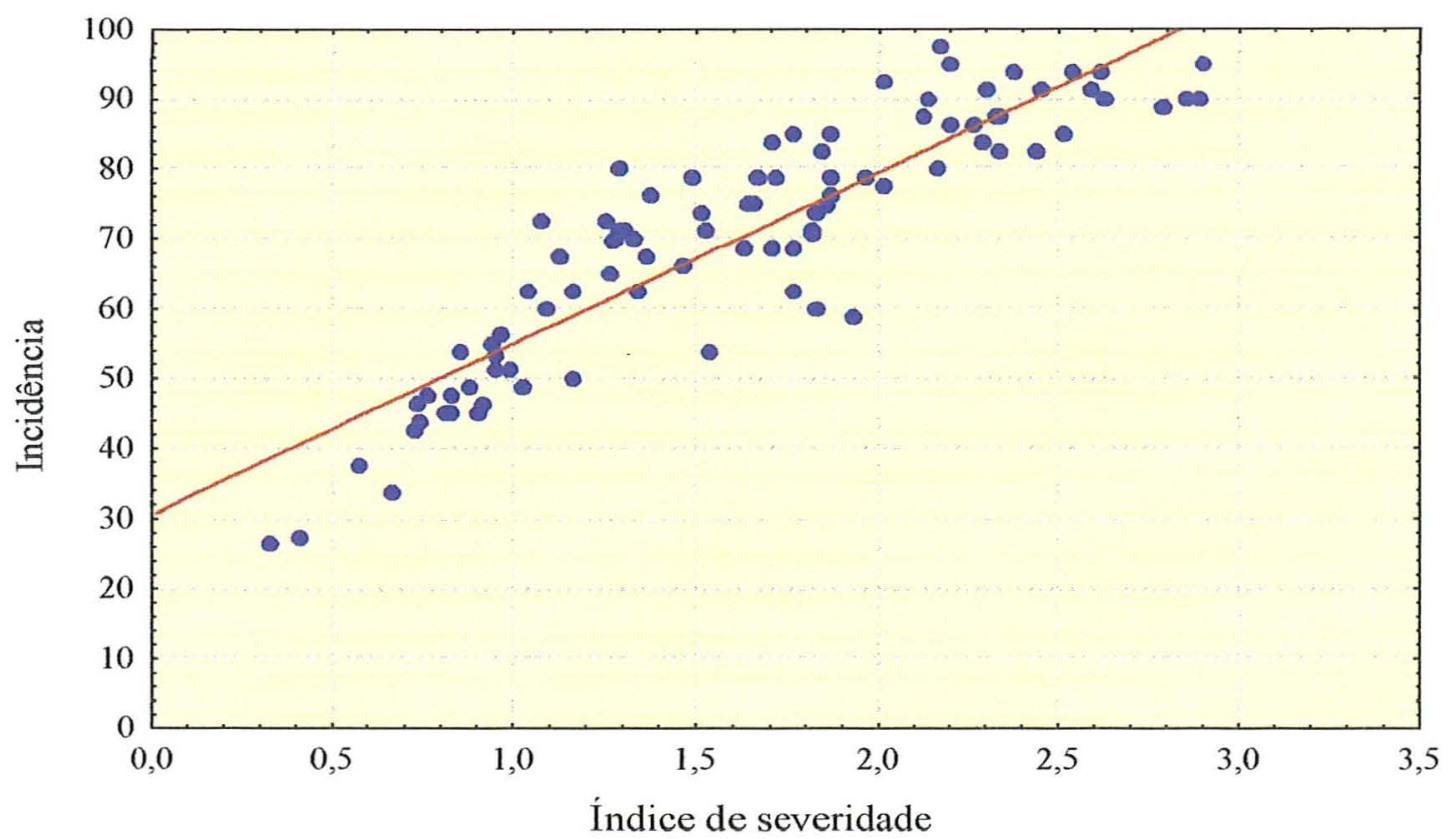

Figura 4 - Relação incidência - severidade da Mancha Preta dos Citros $\left(R^{2}=0,81\right)$ avaliada em dez clones de laranjeira 'Pêra' e cinco variedades afins, em Cordeirópolis-SP, safra 2000.

ATÉ_2 $=116,502-0,697 \times \mathrm{R}^{2}=0,78$

ATÉ_3 $=105,539-0,194 \times R^{2}=0,44$

ATÉ_4 $=102,372-0,067 \times \quad R^{2}=0,25$

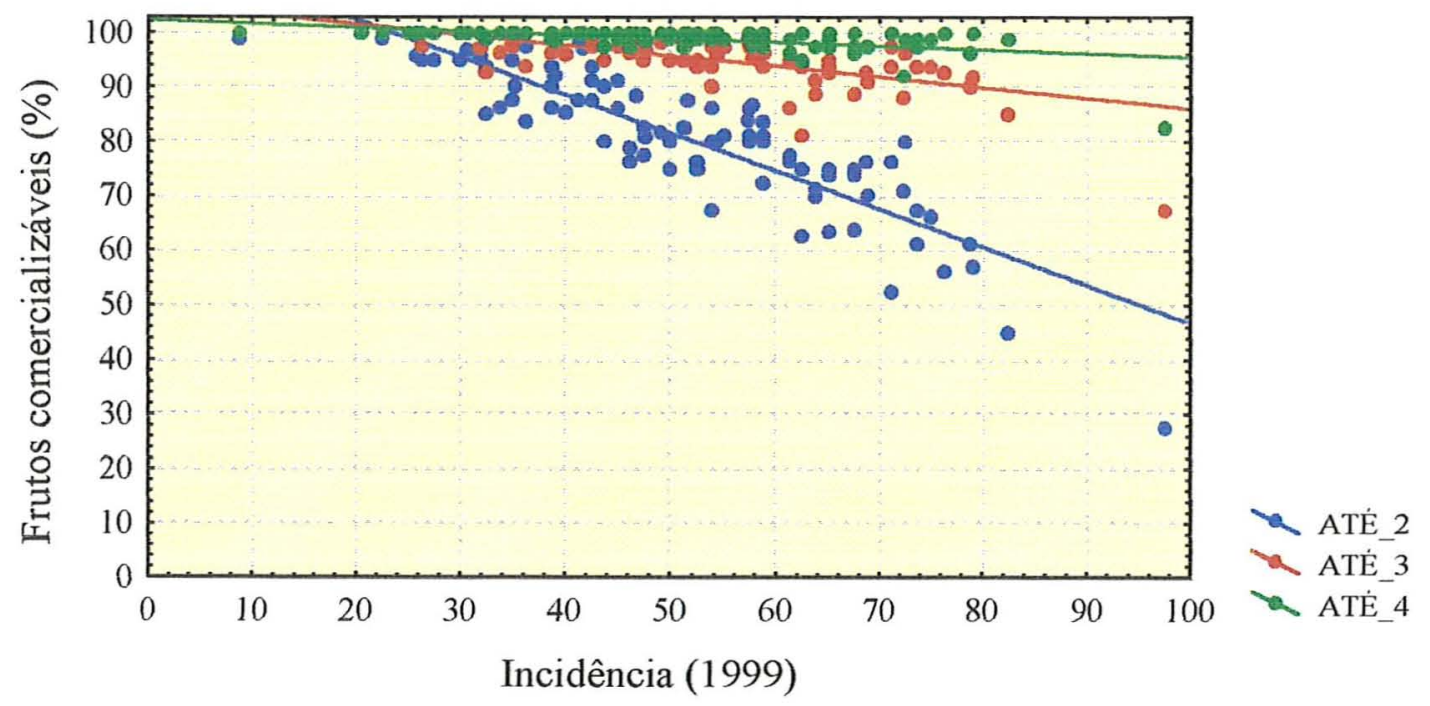

Figura 5 - Correlação entre frutos para comercialização com notas de severidade até 2,3 e 4 e a incidência da Mancha Preta dos Citros, safra 1999. 


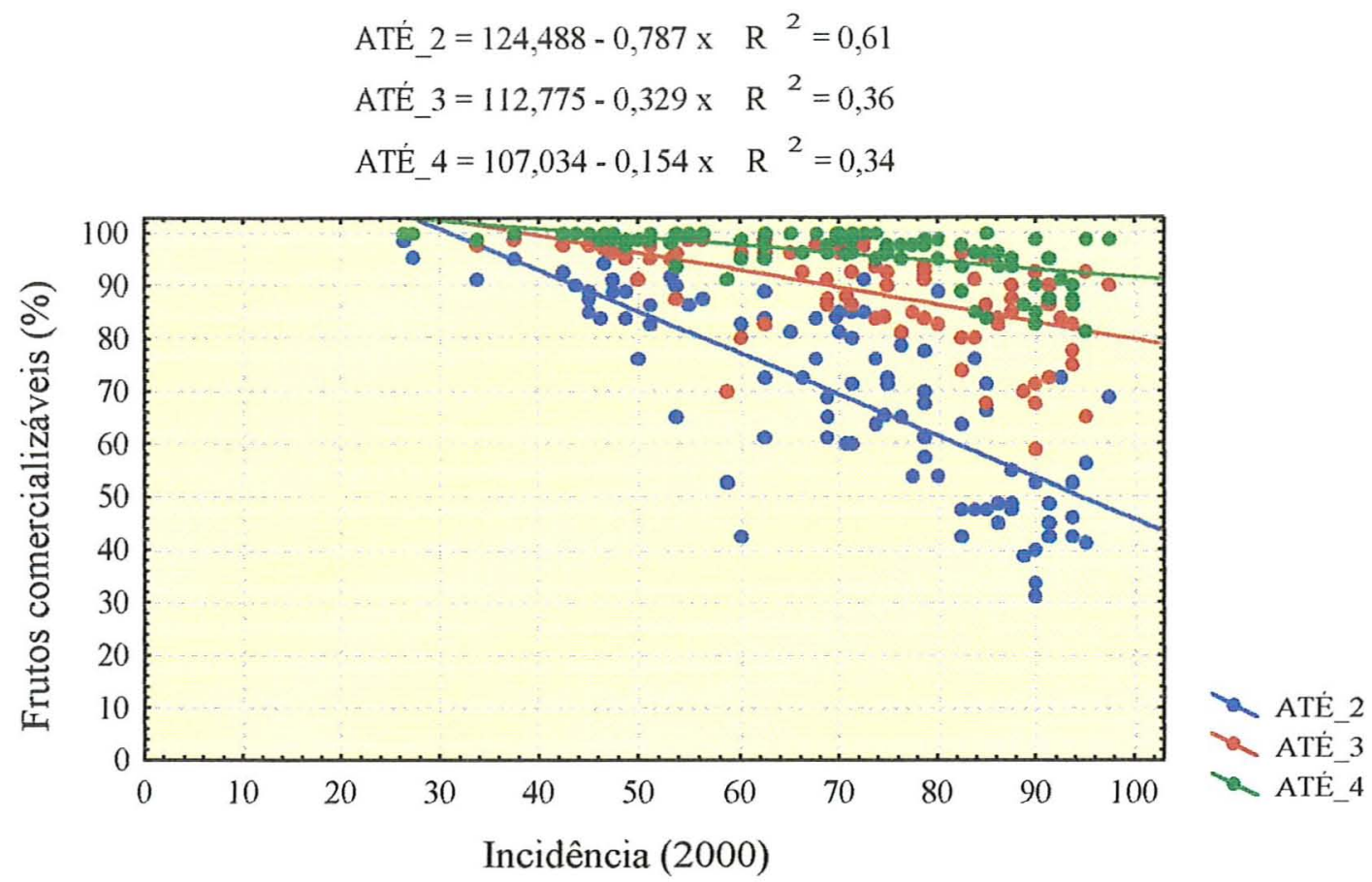

Figura 6 - Correlação entre frutos para comercialização com notas de severidade até 2, 3 e 4 e a incidência da Mancha Preta dos Citros, safra 2000.

Quanto à distribuição da severidade dos sintomas nas plantas, pode-se observar que houve diferenças estatísticas na distribuição da incidência e no índice de severidade entre as diferentes alturas de avaliação nas plantas (Tabela 2), tanto para a safra de 1999 quanto para a de 2000 .

Tabela 2. Distribuição da incidência (\% de frutos com lesões) e da severidade (notas de 0 a 6) da Mancha Preta dos Citros em diferentes alturas de avaliação, nas plantas de dez clones de laranjeira 'Pêra' e cinco variedades afins, em Cordeirópolis-SP, safras 1999 e 2000.

\begin{tabular}{lcccc}
\hline Posições de avaliação & \multicolumn{2}{c}{ Índice de severidade } & \multicolumn{2}{c}{ Incidência da doença } \\
\hline & 1999 & 2000 & 1999 & 2000 \\
\cline { 2 - 5 } Até $1 \mathrm{~m}$ & $1,48 \mathrm{a}$ & $1,23 \mathrm{a}$ & $64,41 \mathrm{a}$ & $51,64 \mathrm{a}$ \\
De $1 \mathrm{a} 2 \mathrm{~m}$ & $1,27 \mathrm{ab}$ & $1,04 \mathrm{a}$ & $58,54 \mathrm{a}$ & $49,00 \mathrm{a}$ \\
Acima de $2 \mathrm{~m}$ & $0,51 \mathrm{c}$ & $0,73 \mathrm{~b}$ & $32,14 \mathrm{c}$ & $40,72 \mathrm{~b}$ \\
Dentro da planta & $1,07 \mathrm{~b}$ & $1,07 \mathrm{a}$ & $48,46 \mathrm{~b}$ & $41,71 \mathrm{~b}$ \\
\hline C.V. & $14,50 \%$ & $14,88 \%$ & $30,58 \%$ & $29,84 \%$
\end{tabular}

Médias seguidas pela mesma letra não diferem significativamente pelo Teste de Tukey a $5 \%$. Os dados de índice de severidade foram transformados pela raiz quadrada, e os dados de incidência pelo arco seno. 
Os menores valores de incidência e do indice de severidade da doença são encontrados nas avaliações acima de 2 metros de altura, sugerindo que os picnidiósporos (esporos assexuais), além dos ascósporos (esporos sexuais), têm influência nas infecções dos frutos, principalmente por respingos de água até 1 metro de altura, pois apesar de não diferir estatisticamente da altura de avaliação de 1 a 2 metros, os valores, tanto de incidência como de índice de severidade da doença, são mais elevados.

No patossistema Citros x Phytophthora, frutos que se desenvolvem nas partes baixas da planta, próximo ao solo, podem ser infectados por respingos de solo que contenham o patógeno. $P$. parasitica produz poucos esporângios na superficie do fruto, sendo esta espécie, pouco disseminada por respingos, restringindo-se à curtas distâncias dentro da planta. Entretanto, $P$. citrophthora e $P$. palmivora, produzem grande quantidade de esporângios na superficie dos frutos infectados, os quais se disseminam rapidamente para outros frutos da planta (Graham \& Timmer, 1995).

Apesar de Kotzé (1981) admitir que para a manifestação dos sintomas e a ocorrência de epidemias, um dos principais fatores é a exposição dos frutos à maior luminosidade, neste experimento constatou-se que os frutos avaliados no interior das plantas, portanto, menos expostos à luz, o índice de severidade da doença não diferiu daqueles frutos avaliados entre 1 e 2 metros. Entretanto, pode-se admitir a formação de um microclima, com alta umidade, ideal para que ocorra as infecções dos frutos no interior das plantas.

\subsection{Capacidade reprodutiva de $G$. citricarpa em folhas autoclavadas in vitro}

Aos 28 dias, observou-se a formação de picnidios com uma massa de esporos, de cor variável, desde acinzentada até branca, significando, respectivamente, o maior e o menor tempo transcorrido da liberação dos picnidiósporos (Figura 7). Houve uma alta correlação entre o número de corpos de frutificação sem a liberação de esporos e o total de corpos de frutificação produzidos por $\mathrm{cm}^{2}\left(\mathrm{R}^{2}=0,99\right.$ e $\left.\mathrm{P}<0,05\right)$.

Houve diferenciação entre as variedades e principalmente entre os clones de laranjeira 'Pêra', através da quantificação total dos corpos de frutificação de $G$. 
citricarpa (Tabela 3). O limoeiro 'Eureka' foi a variedade em que o fungo produziu maior quantidade de corpos de frutificação, estando de acordo com os dados apresentados por Silva \& Aguilar-Vildoso (2000), apesar de não ter diferido estatisticamente de alguns clones de laranjeira 'Pêra'.

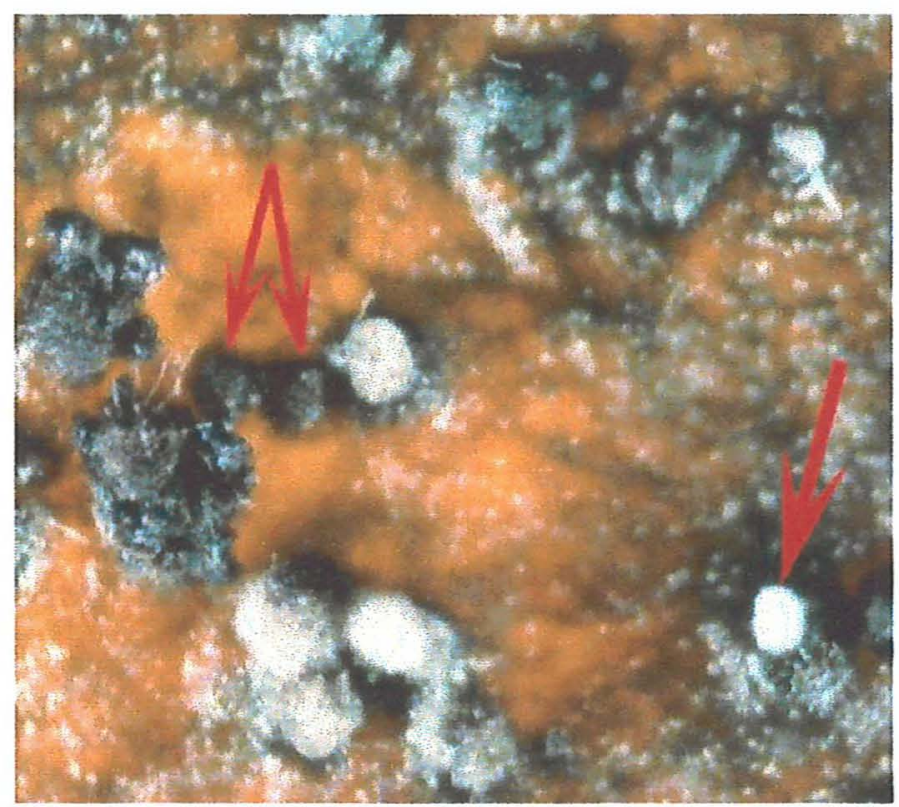

Figura 7 - Estruturas reprodutivas produzidas in vitro, (meio ágar-água a 3\%), por $G$. citricarpa, em folhas previamente autoclavadas de clones de laranjeira 'Pêra', aos 28 dias. Duas setas indicam os corpos de frutificação sem liberação de esporos, e a seta isolada, os picnídios com liberação dos picnidiósporos.

Entre os clones de laranjeira 'Pêra', a ordem decrescente de produção de corpos de frutificação foi a seguinte: Vimusa, R. Gullo 1570/246, EEL, GS 2000 (IAC 2000), Premunizada 1212, Premunizada 1743/82, Olímpia 15161, Bianchi, R. Gullo 1569/244 e Dibbern C.V.

O Poncirus trifoliata que não mostra sintomas da MPC em seus órgãos (folhas e frutos), portanto, indicada no experimento, como variedade resistente, não diferiu estatisticamente do limoeiro 'Eureka' e dos clones de laranjeira 'Pêra' e variedades afins. Provavelmente, esta espécie, apesar de imune, permite a colonização e a produção 
de estruturas reprodutivas do fungo em seu tecidos mortos, servindo como hospedeiro alternativo de G. citricarpa.

Tabela 3. Número médio de corpos de frutificação imaturos (CFI) e total (CFT), por $\mathrm{cm}^{2}$, e porcentagem de picnídios liberando esporos (\% PLE), produzidos in vitro, por Guignardia citricarpa, em folhas autoclavadas de dez clones de laranjeira 'Pêra', cinco variedades afins e duas variedades controle, aos 28 dias, em Cordeirópolis-SP, safra 1999.

\begin{tabular}{lccc}
\hline Variedades & CFI & CFT & $(\%$ PLE) \\
\hline Bianchi & $264 \mathrm{abc}$ & $324 \mathrm{abcd}$ & 14,8 \\
Corsa Tardia & $448 \mathrm{abc}$ & $532 \mathrm{abcd}$ & 15,8 \\
Dibbern C.V. & $135 \mathrm{c}$ & $169 \mathrm{~d}$ & 20,1 \\
EEL & $460 \mathrm{abc}$ & $564 \mathrm{abcd}$ & 18,5 \\
GS. 2000 & $397 \mathrm{abc}$ & $515 \mathrm{abcd}$ & 22,9 \\
Lamb's Summer & $335 \mathrm{abc}$ & $395 \mathrm{abcd}$ & 17,1 \\
Limoeiro ‘Eureka & $628 \mathrm{a}$ & $822 \mathrm{a}$ & 23,6 \\
Olimpia 15161 & $286 \mathrm{abc}$ & $375 \mathrm{abcd}$ & 23,7 \\
Ovale 968 & $216 \mathrm{bc}$ & $263 \mathrm{~cd}$ & 26,6 \\
Ovale San Lio 969 & $276 \mathrm{abc}$ & $342 \mathrm{abcd}$ & 23,0 \\
Poncirus trifoliata & $378 \mathrm{abc}$ & $491 \mathrm{abcd}$ & 23,0 \\
Premunizada 1212 & $366 \mathrm{abc}$ & $468 \mathrm{abcd}$ & 21,7 \\
Premunizada 1743/82 & $327 \mathrm{abc}$ & $400 \mathrm{abcd}$ & 16,3 \\
R. Gullo 1569/244 & $193 \mathrm{bc}$ & $290 \mathrm{bcd}$ & 25,8 \\
R. Gullo 1570/246 & $490 \mathrm{ab}$ & $632 \mathrm{abc}$ & 22,4 \\
Redonda C.N. & $630 \mathrm{a}$ & $802 \mathrm{a}$ & 21,5 \\
Vimusa & $544 \mathrm{ab}$ & $688 \mathrm{ab}$ & 20,9 \\
\hline C.V. & $20,96 \%$ & $19,00 \%$ & \\
\hline
\end{tabular}

Médias seguidas pela mesma letra não diferem significativamente pelo Teste de Tukey a $5 \%$. Os dados foram transformados pela raiz quadrada.

Através deste experimento, pode-se diferenciar melhor a capacidade reprodutiva de $G$. citricarpa em tecidos foliares mortos (autoclavados), podendo-se determinar um componente da resistência horizontal ou parcial entre os clones de laranjeira 'Pêra' e variedades afins. Com isso, pode estar ocorrendo diferenças quanto à densidade de corpos de frutificação nas folhas colonizadas, sendo este, um mecanismo que pode ocorrer nos clones de laranjeira 'Pêra' e variedades afins estudados. Portanto, diferenças na resistência varietal à MPC poderão vir a ser explicadas pelo mecanismo de resistência, relacionado à capacidade reprodutiva do patógeno nos tecidos das folhas 
mortas, mas a correlação com a resistência das variedades no campo, talvez seja perceptível, somente em experimentos apropriados para tal objetivo, visto que, devido à proximidade das plantas no campo, o erro críptico (Vanderplank, 1963) faz com que seja muito dificil detectar estas diferenças em experimentos em que as variedades em estudo estejam muito próximas como nos modelos atuais de experimentação para o estudo de outras características.

Apesar dos resultados obtidos, e a consistência observada na posição das variedades de citros, a técnica de contagem das estruturas reprodutivas, principalmente devido aos altos valores de coeficiente de variação, deve ser melhor estudada e aprimorada para a diferenciação ao nivel de clones dentro de uma mesma variedade.

As informações disponiveis na literatura, relativas à resistência horizontal de acessos de citros à MPC são escassas, e é de extrema importância que venham a ser desenvolvidos novos trabalhos relacionados a este assunto, podendo assim, haver um melhor entendimento destes e de outros componentes de resistência, como a capacidade reprodutiva de $G$. citricarpa nas folhas mortas de citros, permitindo uma melhor diferenciação de clones de uma mesma variedade à MPC.

\subsection{Indução de estruturas reprodutivas de $G$. citricarpa $\mathrm{em}$ folhas destacadas}

Como na capacidade reprodutiva de G. citricarpa em folhas autoclavadas in vitro, a indução de estruturas reprodutivas do fungo em folhas mortas apresentou diferenças significativas na produção de estruturas reprodutivas entre os clones de laranjeira 'Pêra' e variedades afins (Tabela 4). A precisão experimental foi maior na porcentagem da área ocupada pelas estruturas reprodutivas, com coeficiente de variação igual a $41,5 \%$, que na incidência das estruturas de $G$. citricarpa nas folhas (CV $=49,8$ $\%$ ). Os altos valores dos coeficientes de variação são explicados pelo fato das plantas permaneceram expostas à livre infecção pelo fungo e também à idade da folha coletada. Constata-se também, uma alta correlação entre a incidência e porcentagem de área ocupada pelas estruturas $\left(\mathbf{R}^{2}=0,86\right.$ e $\left.\mathbf{P}<0,05\right)$. 
Os coeficientes de variação neste experimento mostram uma alta variabilidade, que também é um fator preponderante na quantificação dos componentes de resistência do feijoeiro à ferrugem (Diniz, 1988). Entretanto, ao se utilizar o tamanho e o número adequados de parcelas, pode-se reduzir o erro experimental e obter resultados mais precisos (Steel \& Torrie, 1980). Além do que, Katsurayama et al. (1993), encontraram uma sensivel redução do $\mathrm{CV}$ com o aumento do número de plantas por parcela, em quatro componentes de resistência do feijoeiro à ferrugem.

Tabela 4. Incidência (\%) de Guignardia citricarpa que naturalmente colonizou as folhas e porcentagem de área ocupada pelas estruturas reprodutivas do fungo, em dez clones de laranjeira 'Pêra' e cinco variedades afins, obtida por decomposição de folhas maduras, em Cordeirópolis-SP, safra 1999.

\begin{tabular}{lcc}
\hline Variedades & Incidência & Area de colonização (\%) \\
\hline Bianchi & $24,27 \mathrm{abc}$ & $5,53 \mathrm{ab}$ \\
Corsa Tardia & $9,10 \mathrm{abcd}$ & $2,76 \mathrm{ab}$ \\
Dibbern C.V. & $13,65 \mathrm{abcd}$ & $1,39 \mathrm{~b}$ \\
EEL & $12,13 \mathrm{abcd}$ & $2,07 \mathrm{ab}$ \\
GS. 2000 & $24,27 \mathrm{abcd}$ & $2,54 \mathrm{ab}$ \\
Lamb's Summer & $7,58 \mathrm{bcd}$ & $0,94 \mathrm{~b}$ \\
Olímpia 15161 & $27,30 \mathrm{ab}$ & $5,71 \mathrm{ab}$ \\
Ovale 968 & $4,55 \mathrm{~cd}$ & $0,29 \mathrm{~b}$ \\
Ovale San Lio 969 & $12,13 \mathrm{abcd}$ & $1,67 \mathrm{ab}$ \\
Premunizada 1212 & $36,35 \mathrm{a}$ & $9,75 \mathrm{a}$ \\
Premunizada $1743 / 82$ & $6,07 \mathrm{bcd}$ & $0,32 \mathrm{~b}$ \\
R. Gullo $1569 / 244$ & $5,97 \mathrm{bcd}$ & $1,02 \mathrm{~b}$ \\
R. Gullo $1570 / 246$ & $3,03 \mathrm{~d}$ & $0,23 \mathrm{~b}$ \\
Redonda C.N. & $4,55 \mathrm{~cd}$ & $0,30 \mathrm{~b}$ \\
Vimusa & $12,13 \mathrm{abcd}$ & $1,91 \mathrm{~b}$ \\
\hline C.V. & $49,83 \%$ & $41,52 \%$ \\
\hline
\end{tabular}

Médias seguidas pela mesma letra não diferem significativamente pelo Teste de Tukey a $5 \%$. Os dados foram transformados pela raiz quadrada.

Nas folhas, não foram encontrados os peritécios onde ocorre a produção dos ascósporos, principal fonte de inóculo da doença (Kotzé, 1963; McOnie, 1964b), provavelmente, devido às folhas não terem atingido um estágio de decomposição em que estejam secas, não quebradiças e com consistência semelhante a de papel, que é quando os peritécios se encontram completos e maduros (Alcoba et al., 2000). Ainda, segundo 
os mesmos autores, os peritécios nunca são encontrados em etapas iniciais de decomposição e ao final deste processo.

\subsection{Colonização natural das folha por $G$. citricarpa}

Entre os clones de laranjeira 'Pêra' e variedades afins estudados, não houve diferenças significativas quanto aos valores referentes à incidência e à densidade de isolamento de colônias de $G$. citricarpa (Tabela 5). A precisão experimental foi maior na densidade de colonização (isolados $\left./ \mathrm{cm}^{2}\right),(\mathrm{CV}=17 \%)$, que na incidência de folhas colonizadas naturalmente por $G$. citricarpa $(\mathrm{CV}=35 \%)$. Os resultados demonstram uma alta correlação entre a incidência e a densidade de colonização, $\operatorname{com} R^{2}=0,82,0$ qual foi significativo a $95 \%$. Isto já era esperado, pois, à medida que há uma maior incidência, maior a probabilidade de novas infecções ocorrerem na mesma folha, aumentando a densidade de colonização.

A não diferenciação entre as variedades cítricas estudadas quanto à colonização natural das folhas, também ocorreu ao se realizar a avaliação da severidade da doença na área experimental, onde obteve-se um comportamento semelhante entre as variedades quanto à suscetibilidade à MPC.

Estes resultados nos sugerem duas possibilidades: 1) realmente não ocorrem diferenças de suscetibilidade entre os clones de laranjeira 'Pêra' e variedades afins à MPC, possuindo os mesmos mecanismos de resistência horizontal, tanto qualitativa como quantitativamente; 2) as diferenças existentes quanto à resistência entre as variedades estudadas não podem ser detectadas no campo, devido ao erro críptico (Vanderplank, 1963) ser muito pronunciado para o delineamento experimental utilizado. Se isto for verdadeiro, o número de plantas por parcela, como a sua disposição, não estariam adequados para as avaliações feitas em programas de melhoramento de citros, principalmente, quando há necessidade de caracterização dos acessos quanto à suscetibilidade a doenças como a MPC, onde a principal fonte de inóculo, os ascósporos, é disseminada pelo vento, relativamente, a longas distâncias. 
Tabela 5. Incidência (\%) e número de colônias por $\mathrm{cm}^{2}$ de área foliar, de Guignardia citricarpa, obtida por isolamento do fungo em meio cenoura-ágar-glicose, de folhas maduras de dez clones de laranjeira 'Pêra' e cinco variedades afins, em Cordeirópolis-SP, safra 2000.

\begin{tabular}{lcc}
\hline Clones & Incidência & Isolados por $\mathrm{cm}^{2}$ \\
\hline Bianchi & 43,33 & 0,87 \\
Corsa Tardia & 58,33 & 1,37 \\
Dibbern C.V. & 43,33 & 0,90 \\
EEL & 40,00 & 0,90 \\
GS 2000 & 46,67 & 1,02 \\
Lamb's Summer & 48,33 & 1,17 \\
Olímpia 15161 & 40,00 & 0,90 \\
Ovale 968 & 33,33 & 0,73 \\
Ovale San Lio 969 & 46,67 & 1,02 \\
Premunizada 1212 & 48,33 & 1,08 \\
Premunizada 1743/82 & 48,33 & 1,00 \\
R. Gullo 1569/244 & 56,67 & 1,57 \\
R. Gullo 1570/246 & 41,67 & 1,03 \\
Redonda C.N & 46,67 & 1,08 \\
Vimusa & 45,00 & 1,02 \\
\hline C.V. & $34,61 \%$ & $16,93 \%$ \\
\hline Osdos 0 & &
\end{tabular}

Os dados foram transformados pela raiz quadrada.

Considerando os trabalhos iniciais de epidemiologia, realizados no Brasil, sobre o padrão espacial da MPC (Spósito et al., 2001), constataram-se que no início da evolução da doença no pomar, as plantas sintomáticas possuem um padrão agregado e que observa-se a ocorrência da doença num raio de 30 metros a partir de uma planta doente. Esta informação é de extrema importância no delineamento experimental em estudos da MPC, pois, a partir destes dados, cada parcela experimental teria no mínimo $3600 \mathrm{~m}^{2}(60 \times 60 \mathrm{~m})$ para se tentar evitar totalmente o erro críptico, entretanto, inviabilizaria no campo, a seleção de um grande número de acessos de citros à MPC. Portanto, a seleção de acessos citricos, no delineamento atual, șomente será possivel quando ocorrer diferenças de penetração dos propágulos do patógeno aos tecidos foliares, ou da casca do fruto, o que não deve ocorrer nos clones de laranjeira 'Pêra' e variedades afins estudados neste trabalho.

Considerando como premissa que não houve diferenças na colonização das folhas e da severidade dos sintomas nos frutos, os resultados dos experimentos de 
capacidade reprodutiva in vitro e em folhas mortas, evidenciam a provável diferenciação entre os clones de laranjeira 'Pêra' e variedades afins, quanto à capacidade de crescimento saprofitico nas folhas mortas e/ou menor favorecimento de outros microrganismos competidores.

\subsection{Produção de frutos}

Os dez clones de laranjeira 'Pêra' e as cinco variedades afins diferiram entre si pelo teste de Tukey a $5 \%$ de significância, quanto à produção (Tabela 6). A variedade afim Redonda C.N. foi a mais produtiva nos dois anos consecutivos de avaliação. Entre os clones de 'Pêra', o Bianchi foi o mais produtivo na safra de 1999 e o Vimusa o mais produtivo na safra 2000. Os clones de 'Pêra' R. Gullo 1569/244 e Premunizada 1212 foram aqueles que tiveram menores produções nas safras de 1999 e 2000, respectivamente.

Em geral, a produção das plantas está abaixo da média brasileira, que é de duas caixas de $40,8 \mathrm{~kg}$ por planta, apesar da variedade afim ter produzido 2,5 caixas na safra de 1999, algumas 'Pêras', como a R. Gullo 1569/244 e R. Gullo 1570/246 não chegaram a atingir 1 caixa por planta. Provavelmente, esta baixa produção deva estar relacionada à idade do pomar e às condições depauperadas de algumas plantas. Além disso, na safra 2000 , houve uma redução da produção das plantas, podendo estar relacionada ao fato das plantas terem tido três floradas devido às condições climáticas do período, havendo plantas que praticamente perderam a primeira florada, e consequentemente, produziram menos.

Em um experimento de comparação de onze clones de laranjeira 'Pêra', na região de Araraquara-SP, no período de 1985 a 1994, Teófilo Sobrinho et al. (1996) obtiveram uma maior produção nos clones Vimusa e Bianchi, observando que o clone Vimusa, pelo conjunto das características avaliadas, poderia ser mais uma opção para os citricultores daquela região. A produção média em 8 anos das seleções estudadas neste trabalho, apresentada por Teófilo Sobrinho et al. (1992) e Domingues et al. (1997a) 
indicaram a variedade afim Redonda C.N. como a mais produtiva, seguida da 'Pêra' GS 2000 e 'Pêra' Premunizada 1743/82. As Ovales foram as menos produtivas.

Tabela 6. Produção de dez clones de laranjeira 'Pêra' e cinco variedades afins, em Cordeirópolis-SP, safras 1999 e 2000.

\begin{tabular}{lcc}
\hline Variedades & 1999 & 2000 \\
\hline & & $\mathrm{Kg} /$ planta \\
\cline { 2 - 3 } Bianchi & $75,45 \mathrm{ab}$ & $44,95 \mathrm{abc}$ \\
Corsa Tardia & $88,42 \mathrm{ab}$ & $66,05 \mathrm{a}$ \\
Dibbern C.V. & $46,55 \mathrm{ab}$ & $41,62 \mathrm{abc}$ \\
EEL & $66,80 \mathrm{ab}$ & $39,83 \mathrm{abc}$ \\
GS 2000 & $52,50 \mathrm{ab}$ & $50,52 \mathrm{abc}$ \\
Lamb's Summer & $55,95 \mathrm{ab}$ & $33,18 \mathrm{abc}$ \\
Olimpia 15161 & $46,28 \mathrm{ab}$ & $40,38 \mathrm{abc}$ \\
Ovale 968 & $69,98 \mathrm{ab}$ & $35,90 \mathrm{abc}$ \\
Ovale San Lio 969 & $64,92 \mathrm{ab}$ & $24,25 \mathrm{bc}$ \\
Premunizada 1212 & $49,10 \mathrm{ab}$ & $15,07 \mathrm{c}$ \\
Premunizada 1743/82 & $74,05 \mathrm{ab}$ & $37,98 \mathrm{abc}$ \\
R. Gullo 1569/244 & $36,77 \mathrm{~b}$ & $17,28 \mathrm{c}$ \\
R. Gullo 1570/246 & $38,88 \mathrm{~b}$ & $26,8 \mathrm{abc}$ \\
Redonda C.N. & $100,63 \mathrm{a}$ & $68,47 \mathrm{a}$ \\
Vimusa & $64,47 \mathrm{ab}$ & $55,80 \mathrm{ab}$ \\
\hline C.V. & $23,89 \%$ & $27,15 \%$ \\
\hline Médias seguidas pela mesma letra não diferem significativamente pelo Teste de Tukey a $5 \%$ Os dados \\
foram transformados pela raiz quadrada.
\end{tabular}

\subsection{Queda de folhas e frutos}

Foram realizadas 34 avaliações durante os meses de agosto de 1999 a dezembro de 2000 (Tabelas 7 e 8), para a queda de folhas. Na Figura 8 , está representada graficamente a curva anual de queda de folhas (mês a mês) de dez clones de laranjeira 'Pêra' e cinco variedades afins, e na Figura 9, a curva anual, com avaliações quinzenais. As curvas quinzenais e mensais de número de folhas caídas por $\mathrm{m}^{2}$ para cada clone e variedade afim, estão apresentadas nos Anexos A e B, respectivamente.

Normalmente, a duração das folhas nas plantas cítricas varia de 1 a 3 anos, e pode ser determinada por vários fatores bióticos e abióticos (Rodriguez, 1987). Nas 
condições experimentais, em Cordeirópolis, observou-se uma queda natural de folhas durante $o$ ano todo, com picos que se concentraram nos meses de agosto e setembro para o ano de 1999 e em junho, julho e novembro de 2000. Segundo Alcoba et al. (2000), na zona citrícola Jujena, na Argentina, a maior queda de folhas se concentra no período que vai de setembro a dezembro, enquanto que em Salta, a maior queda ocorre de dezembro a fevereiro. Ainda segundo os mesmos autores, entre as laranjeiras, limoeiros e pomeleiros, estes últimos são aqueles que apresentam uma maior queda de folhas, servindo de substrato para o desenvolvimento do inóculo primário de G. citricarpa.

Tabela 7. Queda de folhas sobre telas de $1 \mathrm{~m}^{2}$, colocadas sob a copa de dez clones de laranjeira 'Pêra' e cinco variedades afins, em Cordeirópolis-SP. As avaliações foram feitas quinzenalmente de agosto a dezembro de 1999.

\begin{tabular}{lccccc}
\hline Variedades & \multicolumn{5}{c}{ Número de folhas caídas } \\
\cline { 2 - 6 } Bianchi & Ago* & Set* & Out* & Nov* & Dez $^{*}$ \\
\cline { 2 - 6 } Corsa Tardia & 393 & 180 & 69 & 50 & 49 \\
Dibbern C.V. & 489 & 401 & 118 & 46 & 73 \\
EEL & 475 & 279 & 65 & 41 & 69 \\
GS. 2000 & 438 & 227 & 89 & 61 & 61 \\
Lamb's Summer & 227 & 182 & 62 & 29 & 41 \\
Olimpia 15161 & 409 & 346 & 88 & 53 & 78 \\
Ovale 968 & 288 & 198 & 59 & 37 & 43 \\
Ovale San Lio 969 & 404 & 264 & 68 & 32 & 55 \\
Premunizada 1212 & 370 & 274 & 84 & 37 & 60 \\
Premunizada 1743/82 & 146 & 94 & 28 & 28 & 38 \\
R. Gullo 1569/244 & 362 & 201 & 79 & 42 & 55 \\
R. Gullo 1570/246 & 267 & 164 & 48 & 29 & 47 \\
Redonda C.N. & 214 & 195 & 34 & 25 & 31 \\
Vimusa & 571 & 374 & 144 & 128 & 80 \\
. & 388 & 195 & 74 & 42 & 59 \\
\hline
\end{tabular}

* Soma do número médio de folhas caídas em duas avaliações durante o mês.

O desenvolvimento de peritécios nas folhas caidas ao solo depende das infecções que tenham ocorrido durante o período de suscetibilidade no ciclo de vida das folhas (Alcoba et al., 2000). Kotzé (1981) afirma que somente após 50 a 180 dias da queda é que ocorre o desenvolvimento dos ascocarpos de G. citricarpa, ou seja, formação das estruturas reprodutivas sexuais do fungo. Para que ocorra o início do crescimento, produção dessas estruturas e posterior disseminação de G. citricarpa, deve 
haver um período de indução, que é dependente de um processo natural de secagem e umedecimento das folhas e de temperaturas prevalecentes, e segundo Alcoba et al. (2000) do momento da desfolha e da velocidade de decomposição das folhas, estando diretamente relacionado com as precipitações e com a temperatura.

Tabela 8. Queda de folhas sobre telas de $1 \mathrm{~m}^{2}$, colocadas sob a copa de dez clones de laranjeira 'Pêra' e cinco variedades afins, em Cordeirópolis-SP. As avaliações foram feitas quinzenalmente, de janeiro a dezembro de 2000.

\begin{tabular}{lcccccccccccc}
\hline Variedades & \multicolumn{10}{c}{ Número de folhas caídas } \\
\hline & $\mathrm{J}^{*}$ & $\mathrm{~F}^{*}$ & $\mathrm{M}^{*}$ & $\mathrm{~A}^{*}$ & $\mathrm{M}^{*}$ & $\mathrm{~J}^{*}$ & $\mathrm{~J}^{*}$ & $\mathrm{~A}^{*}$ & $\mathrm{~S}^{*}$ & $\mathrm{O}^{*}$ & $\mathrm{~N}^{*}$ & $\mathrm{D}^{*}$ \\
\cline { 2 - 5 } & 45 & 56 & 87 & 44 & 56 & 176 & 162 & 61 & 105 & 102 & 170 & 47 \\
Corsa Tardia & 95 & 67 & 114 & 43 & 63 & 225 & 234 & 86 & 115 & 116 & 205 & 54 \\
Dibbern C.V. & 69 & 66 & 65 & 30 & 54 & 121 & 173 & 61 & 76 & 97 & 176 & 61 \\
EEL & 60 & 51 & 78 & 27 & 43 & 97 & 144 & 69 & 83 & 135 & 237 & 75 \\
GS. 2000 & 37 & 36 & 56 & 42 & 74 & 167 & 182 & 71 & 92 & 64 & 118 & 45 \\
Lamb's Summer & 71 & 65 & 75 & 40 & 44 & 147 & 150 & 64 & 119 & 90 & 172 & 69 \\
Olimpia 15161 & 36 & 41 & 43 & 31 & 31 & 96 & 152 & 52 & 71 & 60 & 126 & 42 \\
Ovale 968 & 71 & 47 & 70 & 31 & 52 & 140 & 219 & 75 & 105 & 78 & 115 & 44 \\
Ovale San Lio 969 & 117 & 82 & 85 & 48 & 82 & 202 & 256 & 98 & 150 & 104 & 126 & 70 \\
Premunizada 1212 & 29 & 29 & 38 & 27 & 36 & 119 & 142 & 34 & 44 & 30 & 45 & 24 \\
Premunizada 1743/82 & 68 & 59 & 99 & 48 & 79 & 186 & 171 & 69 & 97 & 131 & 216 & 72 \\
R. Gullo 1569/244 & 44 & 54 & 50 & 27 & 35 & 116 & 171 & 66 & 66 & 73 & 98 & 48 \\
R. Gullo 1570/246 & 34 & 35 & 43 & 27 & 31 & 112 & 159 & 55 & 60 & 40 & 57 & 37 \\
Redonda C.N. & 31 & 39 & 61 & 28 & 56 & 165 & 162 & 90 & 166 & 162 & 334 & 52 \\
Vimusa & 51 & 52 & 90 & 33 & 48 & 137 & 164 & 56 & 79 & 93 & 154 & 50 \\
\hline
\end{tabular}

* Soma do número médio de folhas caidas em duas avaliaçôes durante cada mês.

Consequentemente, como o desenvolvimento dos ascocarpos ocorre após 50 a 180 dias da queda das folhas, para as condições do experimento, provavelmente, a maior produção das estruturas reprodutivas do fungo ocorreria a partir de setembro, indo até dezembro quando aumentaria a freqüência e intensidade das chuvas, acompanhadas pelas altas temperaturas que favoreceriam a diminuição na queda de folhas e a sua rápida decomposição, diminuindo, assim, o substrato para o desenvolvimento dos corpos de frutificação de G. citricarpa. Porém esta hipótese deva ser melhor estudada. 


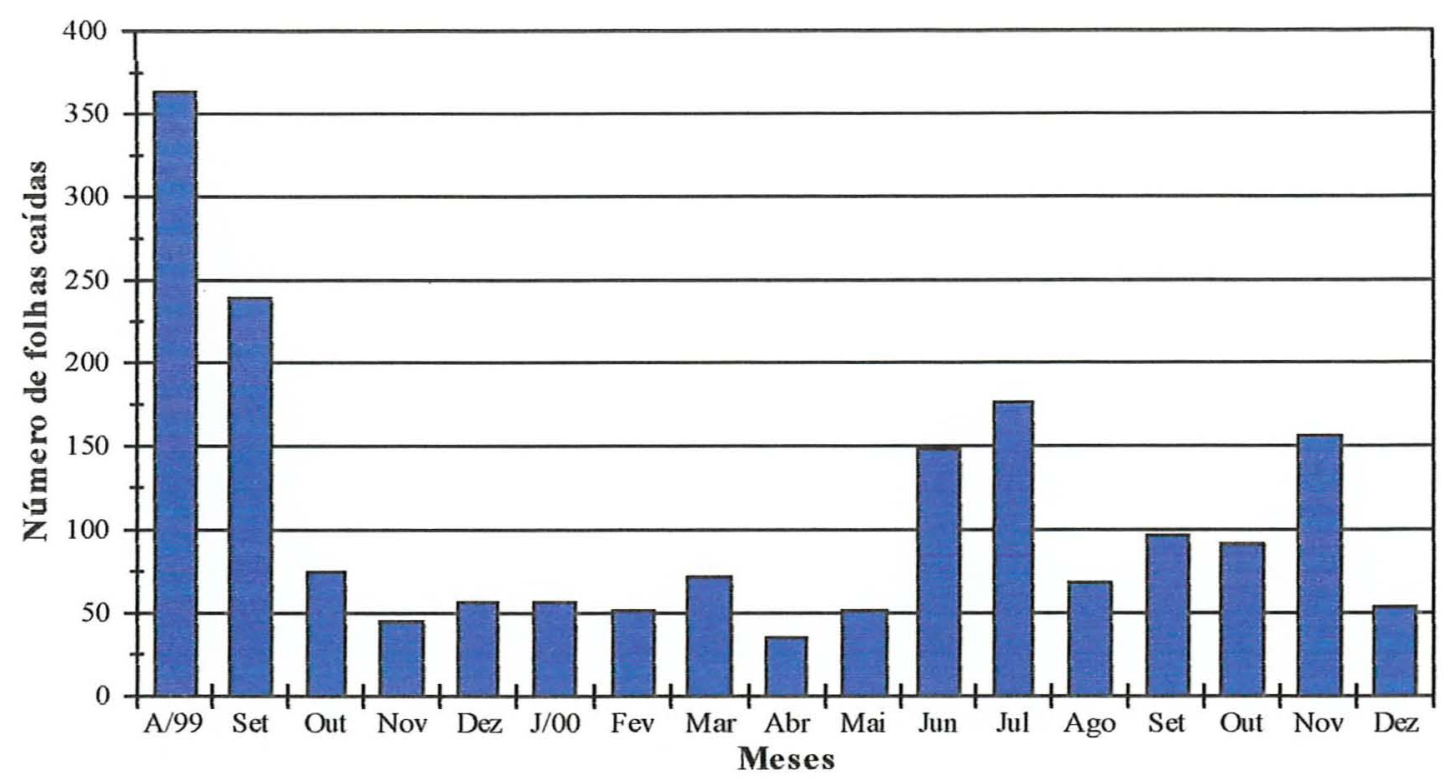

Figura 8 - Curva anual da média de folhas caídas em $1 \mathrm{~m}^{2}$ de dez clones de laranjeira 'Pêra' e cinco variedades afins, obtida mensalmente de agosto de 1999 a dezembro de 2000, em Cordeirópolis-SP.

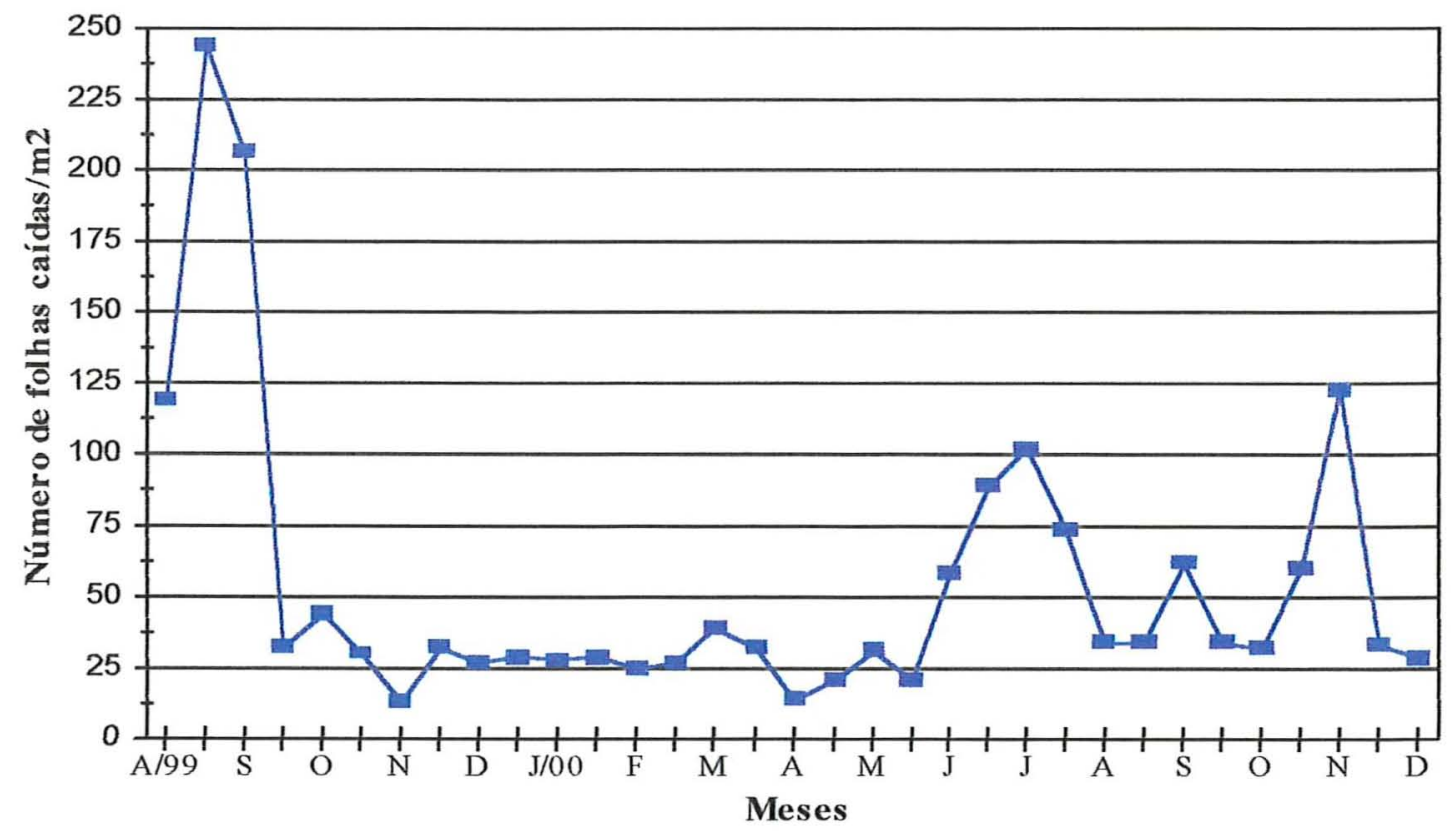

Figura 9 - Curva anual da média de folhas caídas em $1 \mathrm{~m}^{2}$ de dez clones de laranjeira 'Pêra' e cinco variedades afins, obtida quinzenalmente de agosto de 1999 a dezembro de 2000, em Cordeirópolis-SP. 
Quanto à queda de frutos, foram realizadas, quinzenalmente, cinco avaliações nos meses de julho a setembro para as safras de 1999 e 2000.

Calculou-se a porcentagem de frutos caídos com lesões da MPC, para as safras de 1999 e 2000 (Figura 10). Observa-se que houve um aumento no percentual de frutos caídos com lesões da doença com o decorrer das avaliações, para a safra de 1999, o que não aconteceu para a safra de 2000 , podendo estar relacionado, provavelmente, ao fato das três floradas que ocorreram na safra de 2000 , havendo frutos em vários estágios de maturação, e consequentemente, não tendo um aumento contínuo do percentual de frutos caídos com sintomas.

Os frutos caídos foram avaliados, quanto à severidade dos sintomas da doença, na região lateral (Figura 11), próximo ao pedúnculo (Figura 12) e no ápice (Figura 13). Observou-se que a maior parte dos frutos caídos apresentavam notas 3,4 e 5 de severidade da doença na lateral; notas 1,2 e 3 na região próxima ao pedúnculo; e notas 1,2 e 3 na região do ápice.

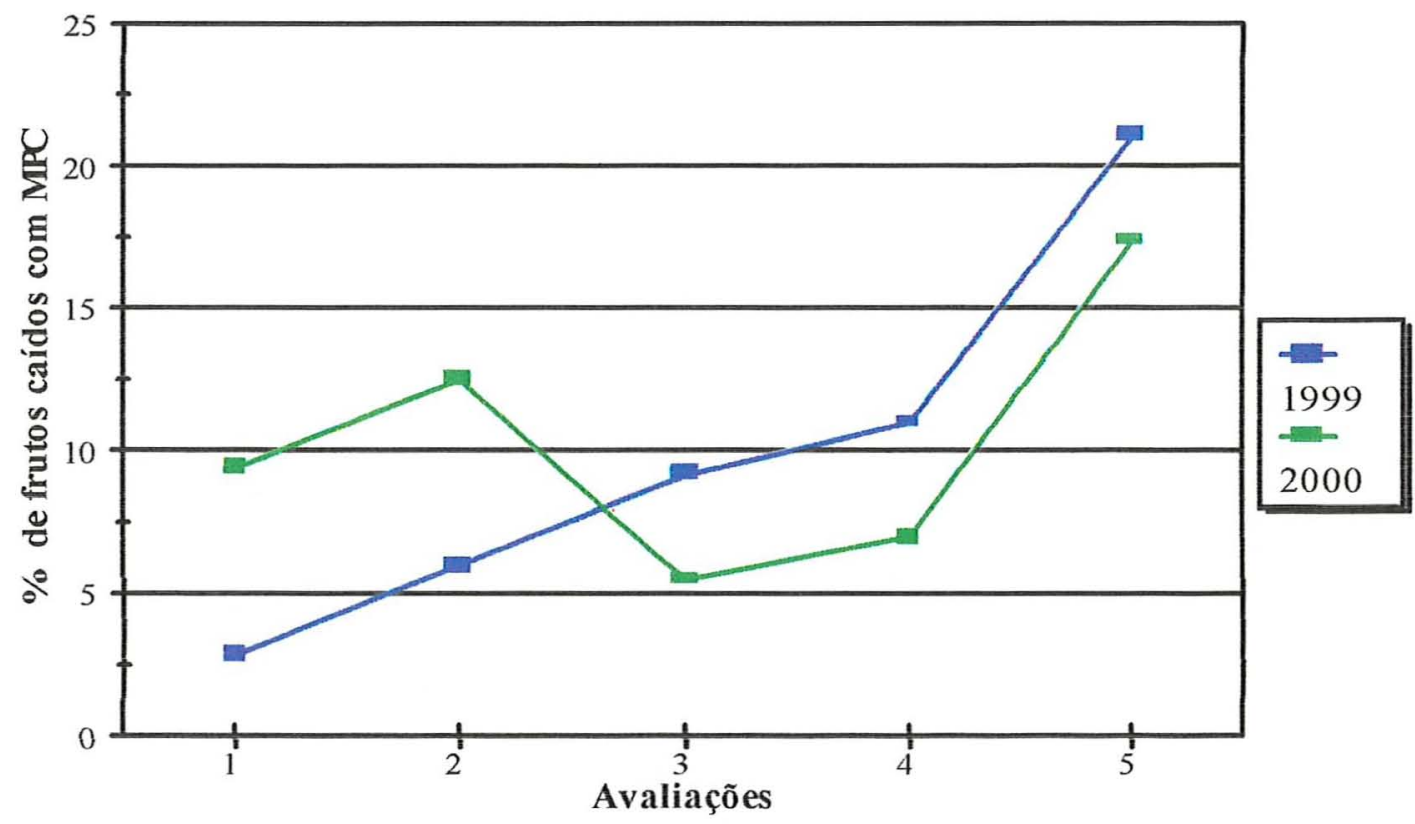

Figura 10 - Porcentagem de frutos caídos com lesões de Mancha Preta dos Citros, em cinco avaliações quinzenais, de julho a setembro, nas safras de 1999 e 2000, em Cordeirópolis-SP. 


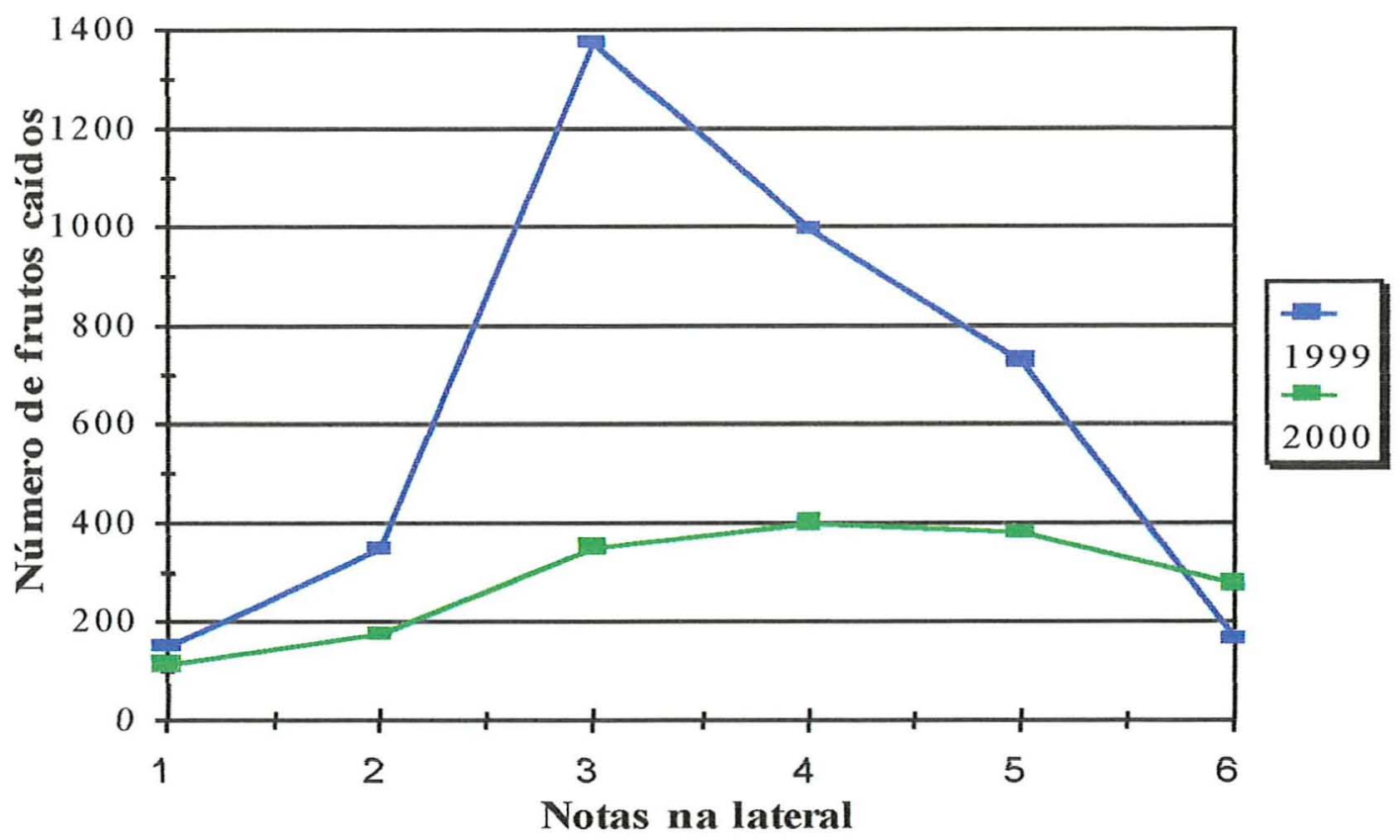

Figura 11 - Número de frutos caídos com sintomas da Mancha Preta dos Citros na região lateral, obtidos em cinco avaliações quinzenais, de julho a setembro, nas safras de 1999 e 2000, em Cordeirópolis-SP.

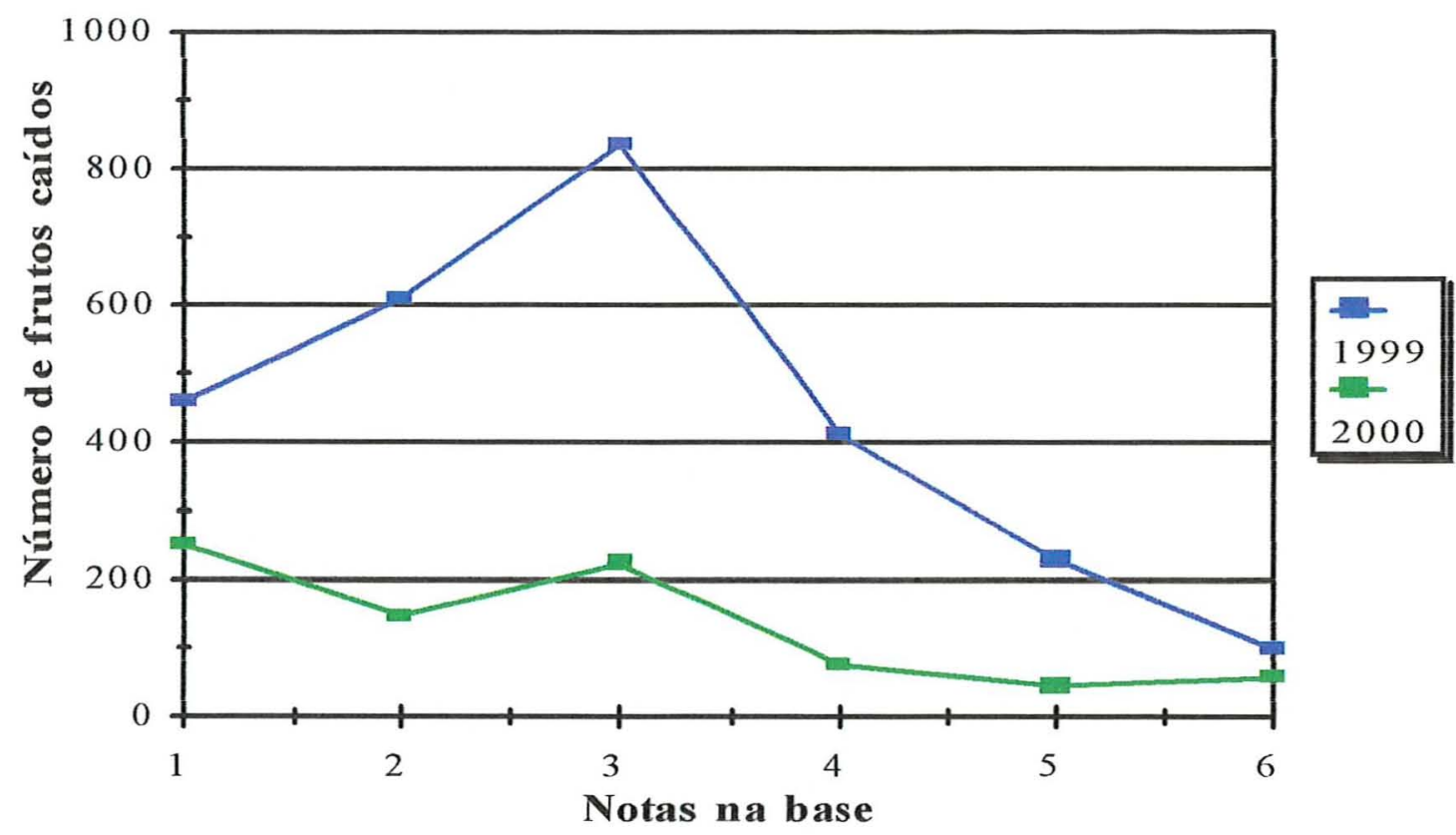

Figura 12 - Número de frutos caídos com sintomas da Mancha Preta dos Citros na região do pedúnculo, obtidos em cinco avaliações quinzenais, de julho a setembro, nas safras de 1999 e 2000, em Cordeirópolis-SP. 


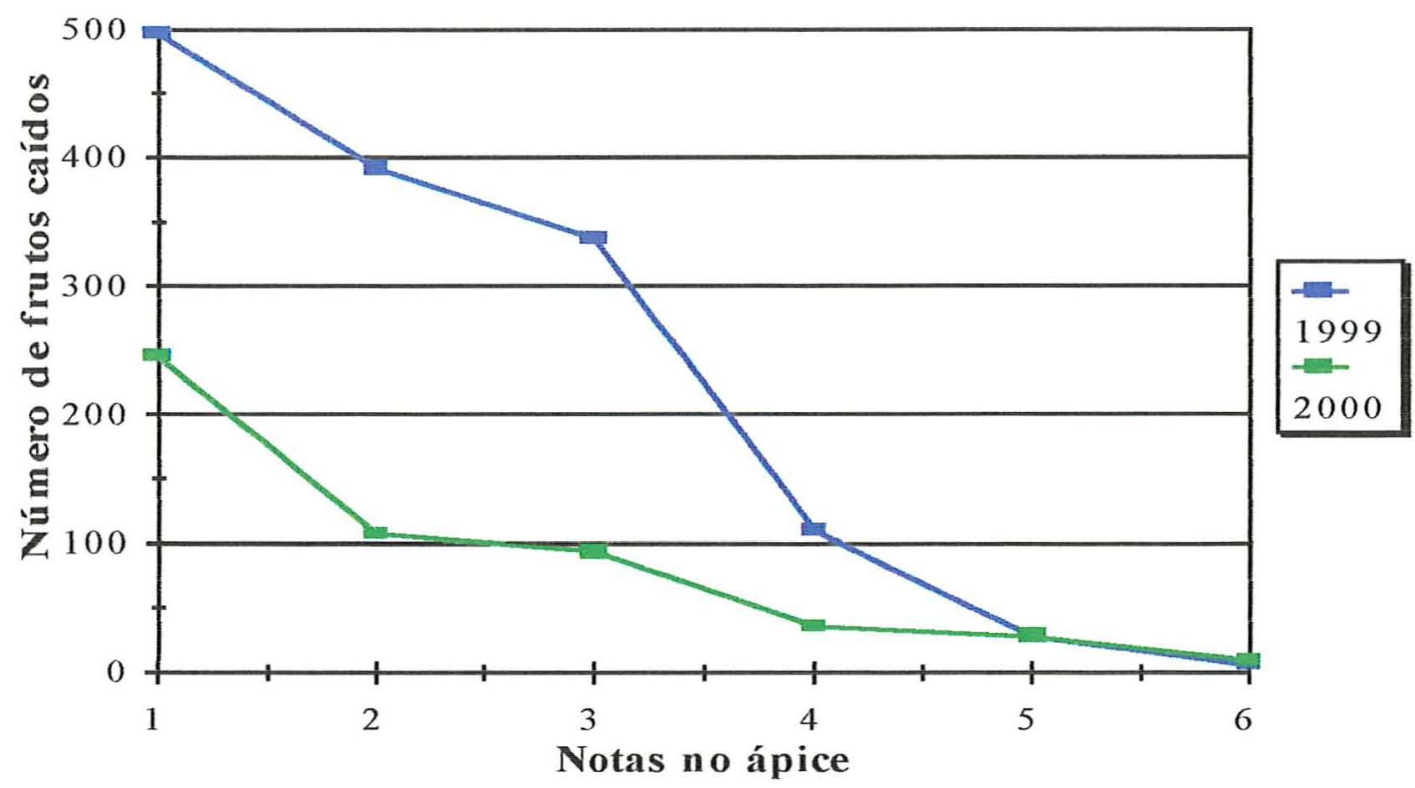

Figura 13 - Número de frutos caídos com sintomas da Mancha Preta dos Citros na região do ápice, obtidos em cinco avaliações quinzenais, de julho a setembro, nas safras de 1999 e 2000, em Cordeirópolis-SP.

Os frutos com sintomas da doença próxima à região do pedúnculo, mesmo com notas 1,2 e 3 de severidade, estão mais sujeitos à queda. Entretanto, os frutos caídos com sintomas na região do ápice apresentaram maiores quantidades de nota 1 , provavelmente, devido à dificuldade de deposição dos esporos nesta região, principalmente dos ascósporos, que são disseminados pelo vento.

\subsection{Desenvolvimento vegetativo das plantas}

As médias do volume e da área de projeção da copa de dez clones de laranjeira 'Pêra' e cinco variedades afins diferiram entre si (Tabela 9).

Há clones de laranjeira 'Pêra' que são muito vigorosos, como o GS 2000 e a variedade afim Redonda C.N., os quais obtiveram maiores volumes de copa, com $73,17 \mathrm{~m}^{3}$ e $66,74 \mathrm{~m}^{3}$, e maiores áreas de projeção da copa, com 23,66 m² e 22,35 m², respectivamente. Já os clones de laranjeira 'Pêra' que obtiveram menores volumes e projeções de copa foram o R. Gullo 1570/246, Olímpia 15161 e Premunizada 1212, com $24,32 \mathrm{~m}^{3}$ e $10,82 \mathrm{~m}^{2}, 23,59 \mathrm{~m}^{3}$ e $10,59 \mathrm{~m}^{2}, 20,41 \mathrm{~m}^{3}$ e $9,28 \mathrm{~m}^{2}$, respectivamente. Os 
resultados de volume de copa estão de acordo com Teófilo Sobrinho et al. (1992). Teófilo Sobrinho et al. (1996), mensuraram menor volume de copa para a 'Pêra' Olímpia 15161 na região de Araraquara-SP, sendo também encontrado no presente trabalho, o menor volume de copa para este clone, em Cordeirópolis-SP.

Domingues (1998), avaliando as mesmas plantas do presente experimento em 1995, encontrou maiores volumes de copa para a variedade Redonda C.N., com 47,96 $\mathrm{m}^{3}$, e para GS 2000 , com $47,70 \mathrm{~m}^{3}$ de copa, e o menor volume de copa foi observado na 'Pêra' Premunizada 1212, com 14,41 m'.

Não houve correlação da severidade da doença com o volume da copa das plantas, mas existe uma tendência de quanto maior o desenvolvimento vegetativo da planta, ou seja, quanto maior o volume da copa, maior a severidade da doença, provavelmente devido ao maior enfolhamento das plantas, e consequentemente, maior queda de folhas, uma vez que a fase sexual de reprodução do fungo se dá nas folhas em decomposição no solo, sendo esta, a mais importante fonte de inóculo para disseminação do fungo.

Tabela 9. Volume e área de projeção da copa das plantas de dez clones de laranjeira 'Pêra' e cinco variedades afins, em Cordeirópolis-SP, safra 1999.

\begin{tabular}{lcc}
\hline Variedades & Volume da copa $\left(\mathrm{m}^{3}\right)$ & Área da copa $\left(\mathrm{m}^{2}\right)$ \\
\hline Bianchi & $40,54 \mathrm{cdefg}$ & $14,92 \mathrm{cde}$ \\
Corsa Tardia & $57,02 \mathrm{abc}$ & $19,57 \mathrm{abc}$ \\
Dibbern C.V. & $33,25 \mathrm{defg}$ & $13,27 \mathrm{cde}$ \\
EEL & $40,99 \mathrm{cdefg}$ & $15,03 \mathrm{cde}$ \\
GS 2000 & $73,17 \mathrm{a}$ & $23,66 \mathrm{a}$ \\
Lamb's Summer & $40,08 \mathrm{cdefg}$ & $15,45 \mathrm{cde}$ \\
Olimpia 15161 & $23,59 \mathrm{fg}$ & $10,59 \mathrm{de}$ \\
Ovale 968 & $43,18 \mathrm{cdef}$ & $15,63 \mathrm{cde}$ \\
Ovale San Lio 969 & $48,09 \mathrm{bcd}$ & $16,20 \mathrm{bcd}$ \\
Premunizada 1212 & $20,41 \mathrm{~g}$ & $9,28 \mathrm{e}$ \\
Premunizada $1743 / 82$ & $45,84 \mathrm{bcde}$ & $16,26 \mathrm{bcd}$ \\
R. Gullo 1569/244 & $31,41 \mathrm{defg}$ & $13,16 \mathrm{cde}$ \\
R. Gullo 1570/246 & $24,32 \mathrm{fg}$ & $10,82 \mathrm{de}$ \\
Redonda C.N. & $66,74 \mathrm{ab}$ & $22,35 \mathrm{ab}$ \\
Vimusa & $41,59 \mathrm{cdefg}$ & $15,53 \mathrm{cde}$ \\
\hline C.V. & $25,82 \%$ & $20,82 \%$ \\
\hline
\end{tabular}

Médias seguidas pela mesma letra não diferem significativamente pelo Teste de Tukey a $5 \%$. 


\subsection{Características externas dos frutos}

\subsubsection{Severidade da Mancha Preta dos Citros na amostra de frutos}

Para a severidade da Mancha Preta dos Citros na amostra de frutos para análise de suco, não houve diferenças estatísticas entre os dez clones de laranjeira 'Pêra' e as cinco variedades afins, tanto para a safra de 1999 quanto para a de 2000 (Tabela 10).

A não diferenciação da incidência e do índice de severidade dos sintomas entre os clones e as variedades afins avaliadas nas amostras para qualidade do fruto, pode reforçar a hipótese da interferência do inóculo de uma planta sobre a outra, e de um bloco sobre o outro, mascarando a resistência horizontal ou parcial, onde a principal fonte de inóculo, os ascósporos, é disseminada pelo vento a longas distâncias, estando envolvido o erro críptico (Vanderplank, 1963) nestes resultados; ou realmente as seleções se comportam semelhantemente em relação à doença.

Tabela 10. Índice de severidade da Mancha Preta dos Citros (notas de 0 a 6) na amostra de dez frutos, para análise de qualidade, em dez clones de laranjeira 'Pêra' e cinco variedades afins, em Cordeirópolis-SP, saftas 1999 e 2000.

\begin{tabular}{|c|c|c|}
\hline Variedades & Indice de severidade (1999) & Indice de severidade $(2000)$ \\
\hline & \multicolumn{2}{|c|}{ Notas de 0 a 6} \\
\hline Bianchi & 1,35 & 1,20 \\
\hline Corsa Tardia & 1,58 & 1,17 \\
\hline Dibbern C.V. & 1,43 & 1,13 \\
\hline EEL & 1,80 & 1,20 \\
\hline GS 2000 & 1,50 & 1,83 \\
\hline Lamb's Summer & 2,42 & 1,28 \\
\hline Olímpia 15161 & 1,37 & 1,00 \\
\hline Ovale 968 & 1,37 & 0,53 \\
\hline Ovale San Lio 969 & 1,17 & 1,18 \\
\hline Premunizada 1212 & 1,10 & 0,93 \\
\hline Premunizada $1743 / 82$ & 1,17 & 0,95 \\
\hline R. Gullo $1569 / 244$ & 1,63 & 1,37 \\
\hline R. Gullo 1570/246 & 1,58 & 0,95 \\
\hline Redonda C.N. & 1,33 & 0,80 \\
\hline Vimusa & 1,47 & 0,93 \\
\hline C.V. & $24,81 \%$ & $15,13 \%$ \\
\hline
\end{tabular}

Os dados foram transformados pela raiz quadrada. 


\subsubsection{Coloração da casca dos frutos}

As notas de coloração da casca dos frutos foram atribuidas de acordo com a escala de notas apresentada na Figura 1. Houve diferenças significativas entre os dez clones de laranjeira 'Pêra' e as cinco variedades afins (Tabela 11).

A 'Pêra' R. Gullo 1570/24 foi o clone que apresentou frutos de coloração mais alaranjada, com nota 5,2, e a variedade afim Corsa Tardia a que apresentou frutos de coloração mais esverdeada, com nota 2,9 , para o ano de 1999 . Já para 2000 , os frutos da variedade afim Redonda C.N. apresentaram nota de coloração da casca em torno de 3,8 e os frutos da variedade afim Ovale 968 apresentaram uma tonalidade mais esverdeada da casca, com nota 2,0 . Nota-se uma grande diferença de tonalidade de cores da casca dos frutos nos anos de 1999 e 2000 . Este fato pode ser explicado devido às várias floradas ocorridas no ano de 1999. Houve três floradas, a primeira praticamente foi perdida devido à escassez de chuva, portanto os frutos se desenvolveram a partir da segunda florada. Consequentemente, como a avaliação de 1999 e 2000 foram feitas na mesma época, os frutos avaliados em 2000 estavam com a casca mais esverdeada.

Não houve correlação da severidade da doença com a coloração da casca dos frutos, porque foi feita apenas uma avaliação de cor para correlacionar com a doença. Se as avaliações de coloração da casca e da severidade da doença fossem feitas no decorrer do crescimento, mudança de cor e maturação dos frutos, provavelmente, haveria uma correlação da cor da casca com a severidade, pois a manifestação dos sintomas da doença é maior nos frutos com casca de tonalidade mais alaranjada. 
Tabela 11. Coloração da casca (Notas de 1 a 6) atribuída aos frutos de dez clones de laranjeira 'Pêra' e cinco variedades afins, em Cordeirópolis-SP, outubro de 1999 e setembro de 2000.

\begin{tabular}{|c|c|c|}
\hline Variedades & Cor do fruto (1999) & Cor do fruto (2000) \\
\hline & \multicolumn{2}{|c|}{ Notas de 1 a 6} \\
\hline Bianchi & $4,6 a b$ & $3,4 a b$ \\
\hline Corsa Tardia & $2,9 d$ & $2,4 \mathrm{bc}$ \\
\hline Dibbern C.V. & $4,7 a b$ & $3,2 a b c$ \\
\hline EEL & $4,4 a b$ & $3,2 a b$ \\
\hline GS 2000 & $4,5 \mathrm{ab}$ & $3,4 a b$ \\
\hline Lamb's Summer & $4,5 \mathrm{ab}$ & $3,1 a b c$ \\
\hline Olímpia 15161 & $4,9 \mathrm{ab}$ & $3,0 \mathrm{abc}$ \\
\hline Ovale 968 & $3,2 \mathrm{~cd}$ & $2,0 \mathrm{c}$ \\
\hline Ovale San Lio 969 & $3,7 \mathrm{bcd}$ & $2,7 \mathrm{abc}$ \\
\hline Premunizada 1212 & $4,7 a b$ & $3,1 a b c$ \\
\hline Premunizada $1743 / 82$ & $4,2 \mathrm{abc}$ & $3,5 \mathrm{ab}$ \\
\hline R. Gullo 1569/244 & $4,9 a b$ & $3,1 \mathrm{abc}$ \\
\hline R. Gullo $1570 / 246$ & $5,2 \mathrm{a}$ & $2,8 a b c$ \\
\hline Redonda C.N. & $4,4 a b$ & $3,8 \mathrm{a}$ \\
\hline Vimusa & $4,8 \mathrm{ab}$ & $2,8 a b c$ \\
\hline C.V. & $12,67 \%$ & $20,55 \%$ \\
\hline
\end{tabular}

Médias seguidas pela mesma letra não diferem significativamente pelo Teste de Tukey a 5\%.

\subsubsection{Morfologia dos frutos}

\subsubsection{Altura e largura dos frutos}

Houve diferenças estatísticas entre os dez clones de laranjeira 'Pêra' e as cinco variedades afins, quanto à altura (A), largura (L) e $\mathrm{A} / \mathrm{L}$ dos frutos (Tabelas 12 e 13). Foram observados que o clone de laranjeira Pêra' e a variedade afim com frutos de maiores médias de altura e largura foram, respectivamente, GS 2000 e Ovale San Lio 969 , tendo mais de $7 \mathrm{~cm}$ de altura e acima de $6,2 \mathrm{~cm}$ de largura, para a safra de 1999. Já para o ano de 2000, o clone de laranjeira 'Pêra' e a variedade afim que apresentaram frutos de maiores médias de altura e largura foram, respectivamente, GS 2000 e Redonda C.N., tendo mais de $6,5 \mathrm{~cm}$ de altura e acima de $6 \mathrm{~cm}$ de largura. A 'Pêra' GS 2000 também foi a que apresentou maiores valores médios de altura e largura, nas 
avaliações feitas por Domingues et al. (1997), nesta mesma área experimental, quando as plantas se encontravam no $12^{\circ}$ ano de produção, em 1995.

Todas as variedades apresentaram dimensões satisfatórias para o mercado de frutas frescas, ou seja, acima de $6 \mathrm{~cm}$ de altura e em torno ou acima de $6 \mathrm{~cm}$ de largura, para o ano agrícola de 1999. Porém, no ano agrícola de 2000, a 'Pêra' R. Gullo 1570/246 e as variedades afins Corsa Tardia e Lamb's Summer não apresentaram tamanho de frutos suficientemente satisfatórios para o mercado de frutas frescas.

Nos dois anos consecutivos, a variedade afim Redonda C.N. foi a que apresentou frutos com uma menor relação $\mathrm{A} / \mathrm{L}$, portanto seus frutos são de formato mais arredondado, ou seja, esféricos, estando estes resultados de acordo com Domingues (1998).

Tabela 12. Altura, largura e relação entre a altura e a largura (A/L) de frutos maduros de dez clones de laranjeira 'Pêra' e cinco variedades afins, em CordeirópolisSP, safra 1999.

\begin{tabular}{lccc}
\hline Variedades & Altura $(\mathrm{cm})$ & Largura $(\mathrm{cm})$ & A/L \\
\hline Bianchi & $6,62 \mathrm{abcd}$ & $5,93 \mathrm{abcdef}$ & $1,12 \mathrm{a}$ \\
Corsa Tardia & $6,73 \mathrm{abcd}$ & $6,20 \mathrm{abcd}$ & $1,09 \mathrm{ab}$ \\
Dibbern C.V. & $6,48 \mathrm{bcd}$ & $5,73 \mathrm{def}$ & $1,13 \mathrm{a}$ \\
EEL & $6,70 \mathrm{abcd}$ & $6,00 \mathrm{abcde}$ & $1,11 \mathrm{ab}$ \\
GS 2000 & $7,17 \mathrm{a}$ & $6,42 \mathrm{a}$ & $1,12 \mathrm{a}$ \\
Lamb's Summer & $6,18 \mathrm{~d}$ & $5,47 \mathrm{f}$ & $1,13 \mathrm{a}$ \\
Olimpia 15161 & $6,53 \mathrm{bcd}$ & $5,93 \mathrm{abcdef}$ & $1,10 \mathrm{ab}$ \\
Ovale 968 & $6,90 \mathrm{abc}$ & $6,25 \mathrm{abc}$ & $1,11 \mathrm{ab}$ \\
Ovale San Lio 969 & $7,02 \mathrm{ab}$ & $6,22 \mathrm{abcd}$ & $1,12 \mathrm{a}$ \\
Premunizada 1212 & $6,50 \mathrm{bcd}$ & $5,78 \mathrm{cdef}$ & $1,12 \mathrm{a}$ \\
Premunizada $1743 / 82$ & $6,60 \mathrm{abcd}$ & $5,92 \mathrm{bcdef}$ & $1,12 \mathrm{a}$ \\
R. Gullo $1569 / 244$ & $6,65 \mathrm{abcd}$ & $5,98 \mathrm{abcde}$ & $1,11 \mathrm{ab}$ \\
R. Gullo $1570 / 246$ & $6,42 \mathrm{~cd}$ & $5,67 \mathrm{ef}$ & $1,13 \mathrm{a}$ \\
Redonda C.N. & $6,68 \mathrm{abcd}$ & $6,32 \mathrm{ab}$ & $1,06 \mathrm{~b}$ \\
Vimusa & $6,45 \mathrm{bcd}$ & $6,10 \mathrm{abcde}$ & $1,09 \mathrm{ab}$ \\
\hline C.V. & $4,43 \%$ & $4,10 \%$ & $2,52 \%$ \\
\hline
\end{tabular}

Médias seguidas pela mesma letra não diferem significativamente pelo Teste de Tukey a $5 \%$. 
Tabela 13. Altura, largura e relação entre a altura e a largura (A/L) de frutos maduros de dez clones de laranjeira 'Pêra' e cinco variedades afins, em CordeirópolisSP, safra 2000.

\begin{tabular}{lccc}
\hline Variedades & Altura $(\mathrm{cm})$ & Largura $(\mathrm{cm})$ & $\mathrm{A} / \mathrm{L}$ \\
\hline Bianchi & $6,02 \mathrm{ab}$ & $5,62 \mathrm{bc}$ & $1,07 \mathrm{abcd}$ \\
Corsa Tardia & $5,82 \mathrm{~b}$ & $5,45 \mathrm{c}$ & $1,07 \mathrm{abcd}$ \\
Dibbern C.V. & $6,03 \mathrm{ab}$ & $5,55 \mathrm{c}$ & $1,08 \mathrm{abcd}$ \\
EEL & $5,98 \mathrm{ab}$ & $5,60 \mathrm{bc}$ & $1,06 \mathrm{abcd}$ \\
GS 2000 & $6,57 \mathrm{a}$ & $6,05 \mathrm{ab}$ & $1,09 \mathrm{abcd}$ \\
Lamb's Summer & $5,88 \mathrm{~b}$ & $5,33 \mathrm{c}$ & $1,11 \mathrm{a}$ \\
Olimpia 15161 & $5,93 \mathrm{ab}$ & $5,63 \mathrm{bc}$ & $1,06 \mathrm{~cd}$ \\
Ovale 968 & $6,17 \mathrm{ab}$ & $5,60 \mathrm{bc}$ & $1,09 \mathrm{abc}$ \\
Ovale San Lio 969 & $6,28 \mathrm{ab}$ & $5,70 \mathrm{bc}$ & $1,10 \mathrm{ab}$ \\
Premunizada 1212 & $6,08 \mathrm{ab}$ & $5,60 \mathrm{bc}$ & $1,09 \mathrm{abc}$ \\
Premunizada $1743 / 82$ & $6,07 \mathrm{ab}$ & $5,63 \mathrm{bc}$ & $1,07 \mathrm{abcd}$ \\
R. Gullo 1569/244 & $6,00 \mathrm{ab}$ & $5,68 \mathrm{bc}$ & $1,06 \mathrm{bcd}$ \\
R. Gullo 1570/246 & $5,78 \mathrm{~b}$ & $5,33 \mathrm{c}$ & $1,08 \mathrm{abcd}$ \\
Redonda C.N. & $6,58 \mathrm{a}$ & $6,32 \mathrm{a}$ & $1,04 \mathrm{~d}$ \\
Vimusa & $6,10 \mathrm{ab}$ & $5,58 \mathrm{c}$ & $1,08 \mathrm{abcd}$ \\
\hline C.V. & $5,27 \%$ & $4,03 \%$ & $2,12 \%$ \\
\hline
\end{tabular}

Médias seguidas pela mesma letra não diferem significativamente pelo Teste de Tukey a $5 \%$.

\subsubsection{Massa dos frutos}

Houve diferenças significativas entre os dez clones de laranjeira 'Pêra' e as cinco variedades afins quanto à massa média de dez frutos para as safras de 1999 e 2000 (Tabela 14).

As plantas de 'Pêra' GS 2000 produziram frutos de maior massa, com $148,5 \mathrm{~g}$ e 137,7 g, estando de acordo com Domingues et al. (1997), e a 'Pêra' R. Gullo 1570/246 $(108,5 \mathrm{~g}$ e $87,4 \mathrm{~g})$ e a variedade afim Lamb's Summer $(94,3 \mathrm{~g}$ e $92,0 \mathrm{~g})$, produziram frutos de menor massa média, nos dois anos consecutivos de avaliação.

Teófilo Sobrinho et al. (1992), em experimento de competição entre clones de laranjeira 'Pêra' na Região de Limeira, relatam que os clones que produziram frutos de maior massa média foram EEL (174 g) e GS 2000 (170 g), e aqueles com frutos de menor massa média foram Vimusa (145 g) e Premunizado 1212 (149 g). 
Tabela 14. Massa média (g) de dez frutos de dez clones de laranjeira 'Pêra' e cinco variedades afins, em Cordeirópolis-SP, safras 1999 e 2000.

\begin{tabular}{lcc}
\hline Variedades & Massa média (1999) & Massa média (2000) \\
\hline & & $\mathrm{g}$ \\
Bianchi & $120,6 \mathrm{abc}$ & $103,9 \mathrm{ab}$ \\
Corsa Tardia & $126,1 \mathrm{ab}$ & $103,4 \mathrm{ab}$ \\
Dibbern C.V. & $109,2 \mathrm{bc}$ & $103,6 \mathrm{ab}$ \\
EEL & $125,5 \mathrm{ab}$ & $107,1 \mathrm{ab}$ \\
GS 2000 & $148,5 \mathrm{a}$ & $137,7 \mathrm{a}$ \\
Lamb's Summer & $94,3 \mathrm{c}$ & $92,0 \mathrm{~b}$ \\
Olímpia 15161 & $117,8 \mathrm{bc}$ & $98,9 \mathrm{ab}$ \\
Ovale 968 & $135,9 \mathrm{ab}$ & $100,2 \mathrm{ab}$ \\
Ovale San Lio 969 & $132,5 \mathrm{ab}$ & $111,3 \mathrm{ab}$ \\
Premunizada 1212 & $112,1 \mathrm{bc}$ & $99,6 \mathrm{ab}$ \\
Premunizada 1743/82 & $121,4 \mathrm{abc}$ & $126,4 \mathrm{ab}$ \\
R. Gullo 1569/244 & $121,6 \mathrm{abc}$ & $108,5 \mathrm{ab}$ \\
R. Gullo 1570/246 & $108,5 \mathrm{c}$ & $87,4 \mathrm{~b}$ \\
Redonda C.N. & $130,9 \mathrm{ab}$ & $134,2 \mathrm{a}$ \\
Vimusa & $114,1 \mathrm{bc}$ & $97,5 \mathrm{ab}$ \\
\hline C.V. & $12,01 \%$ & $18,58 \%$ \\
\hline
\end{tabular}

Médias seguidas pela mesma letra não diferem significativamente pelo Teste de Tukey a 5\%.

\subsubsection{Formato, forma da base e do ápice dos frutos}

Com relação ao formato dos frutos, excetuando-se a variedade afim Ovale 968, todas as outras variedades afins e os clones de laranjeira 'Pêra' apresentaram-se semelhantes, com formato esferóide, segundo o formato descrito no Descriptors for citrus (1999). Do total de frutos avaliados para todas as variedades, $76,1 \%$ apresentaram um formato esferóide e $23,9 \%$ um formato elipsóide. O clone de 'Pêra' Dibbern apresentou $100 \%$ dos frutos com formato esferóide, e a variedade afim Ovale 968 apresentou $61,7 \%$ de seus frutos com formato elipsóide e $38,3 \%$ com formato esferóide. Domingues et al. (1997) relataram que doze clones de laranjeira 'Pêra' apresentaram formato típico, ou seja, largamente obovalados.

Quanto à forma da base, $52,2 \%$ dos frutos apresentaram forma truncada e $47,8 \%$ apresentaram forma convexa. Já para a forma do ápice, a maioria dos frutos apresentaram forma truncada, totalizando $93,7 \%$, e 6,3 \% apresentaram uma forma arredondada. 


\subsubsection{4 Ângulo e achatamento da região basal do fruto}

Não houve diferenças significativas, pelo teste de Tukey a 5\% de significância, entre os dez clones de laranjeira 'Pêra' e as cinco variedades afins quanto ao ângulo e achatamento da região basal dos frutos para a safra de 2000 (Tabela 15). 0 ângulo e o achatamento da região basal do fruto não se correlacionaram com o índice de severidade dos sintomas da doença.

$\mathrm{O}$ ângulo do ombro do fruto variou de $31,55^{\circ}$ para a variedade afim Redonda C.N. a $34,71^{\circ}$ para a 'Pêra' R. Gullo $1570 / 246$ e o achatamento da região basal variou de $2,03 \mathrm{~cm}$ para a variedade afim Lamb's Summer a $2,52 \mathrm{~cm}$ para a 'Pêra' GS 2000.

Tabela 15. Ângulo e achatamento da região basal, próxima ao pedúnculo dos frutos de dez clones de laranjeira 'Pêra' e cinco variedades afins, em CordeirópolisSP, safra 2000.

\begin{tabular}{lcc}
\hline Variedades & Angulo $\left(^{\circ}\right)$ & Achatamento (cm) \\
\hline Bianchi & 33,64 & 2,36 \\
Corsa Tardia & 32,30 & 2,33 \\
Dibbern C.V. & 34,20 & 2,48 \\
EEL & 34,16 & 2,43 \\
GS 2000 & 32,29 & 2,52 \\
Lamb's Summer & 31,95 & 2,03 \\
Olímpia 15161 & 33,69 & 2,43 \\
Ovale 968 & 33,06 & 2,31 \\
Ovale San Lio 969 & 33,61 & 2,42 \\
Premunizada 1212 & 33,93 & 2,46 \\
Premunizada 1743/82 & 31,93 & 2,35 \\
R. Gullo 1569/244 & 32,88 & 2,34 \\
R. Gullo 1570/246 & 34,71 & 2,28 \\
Redonda C.N. & 31,55 & 2,51 \\
Vimusa & 32,25 & 2,10 \\
\hline C.V. & $9,08 \%$ & $13,12 \%$ \\
\hline
\end{tabular}




\subsubsection{Espessura da casca, do mesocarpo e do epicarpo dos frutos}

Houve diferenças entre os clones de laranjeira 'Pêra' e as variedades afins, Quanto às médias da espessura do epicarpo (Tabelas 16 e 17), do mesocarpo (Tabelas 18 e 19) e da casca (Tabelas 20 e 21), medidos nas regiões superior, mediana e inferior dos frutos, respectivamente, para as safras de 1999 e 2000. Pelos resultados, observa-se que na região superior do fruto, tanto o epicarpo como o mesocarpo e, consequentemente, a casca, são mais espessos que nas regiões mediana e inferior dos frutos.

A espessura total do epicarpo (Tabelas 16 e 17), camada mais externa da casca, variou de $0,14 \mathrm{~cm}$ para os clones de 'Pêra' Olímpia 15161, R. Gullo 1569/244 e Vimusa a $0,19 \mathrm{~cm}$ para a variedade afim Redonda C.N., na safra de 1999 ; e de $0,13 \mathrm{~cm}$ para os clones de 'Pêra' Bianchi, EEL e R. Gullo $1569 / 244$ a $0,17 \mathrm{~cm}$ para a variedade afím Redonda C.N., na safra de 2000. Domingues (1998), encontrou maior espessura do epicarpo na 'Pêra' R. Gullo 1570/246 e 'Pêra' EEL, com valores acima de 0,12 cm.

A espessura total do mesocarpo dos frutos (Tabelas 18 e 19), outro componente que determina a espessura da casca do fruto, variou de $0,27 \mathrm{~cm}$ para a 'Pêra' Dibbern C.V. a 0,41 cm para a 'Pêra' GS 2000, na safra de 1999. Em 2000, a espessura do mesocarpo de $0,27 \mathrm{~cm}$ para a 'Pêra' EEL a $0,38 \mathrm{~cm}$ para os clones de 'Pêra' GS $2000 \mathrm{e}$ Premunizada 1212. Domingues (1998), encontrou maior espessura do mesocarpo nas 'Pêras' GS 2000 e R. Gullo 1570/246, com valores acima de $0,35 \mathrm{~cm}$, e menores espessuras nas 'Pêras' Dibbern C.V. e Olímpia, com valores abaixo de $0,25 \mathrm{~cm}$.

A espessura total da casca variou de $0,42 \mathrm{~cm}$ para o clone de laranjeira 'Pêra' Dibbern C.V. a 0,59 cm para a 'Pêra' GS 2000, na safra de 1999. Já para a safra e 2000, a espessura total da casca variou de $0,41 \mathrm{~cm}$ para os clones de 'Pêra' R. Gullo 1569/244 e EEL a $0,53 \mathrm{~cm}$ para a 'Pêra' GS 2000 e para a variedade afim redonda C.N. Domingues et al. (1997) relataram que a espessura da casca dos frutos observada em doze clones de laranjeira 'Pêra', variou de $0,32 \mathrm{~cm}$ para a 'Pêra' Olímpia 15161 a 0,48 cm para os clones de 'Pêra' Vimusa, GS 2000 e Premunizada 1212. 
Tabela 16. Espessura de três regiões (superior, mediana e inferior) e espessura média do epicarpo (cm), de quatro frutos de dez clones de laranjeira 'Pêra' e cinco variedades afins, em Cordeirópolis-SP, safra 1999.

\begin{tabular}{lcccc}
\hline Variedades & Superior & Mediana & Inferior & Média \\
\hline Bianchi & $0,19 \mathrm{bc}$ & $0,16 \mathrm{ab}$ & $0,13 \mathrm{~b}$ & $0,16 \mathrm{bc}$ \\
Corsa Tardia & $0,17 \mathrm{c}$ & $0,16 \mathrm{ab}$ & $0,14 \mathrm{ab}$ & $0,15 \mathrm{bc}$ \\
Dibbern C.V. & $0,19 \mathrm{bc}$ & $0,15 \mathrm{~b}$ & $0,12 \mathrm{~b}$ & $0,15 \mathrm{bc}$ \\
EEL & $0,19 \mathrm{bc}$ & $0,16 \mathrm{ab}$ & $0,14 \mathrm{~b}$ & $0,16 \mathrm{bc}$ \\
GS 2000 & $0,24 \mathrm{a}$ & $0,16 \mathrm{ab}$ & $0,14 \mathrm{~b}$ & $0,18 \mathrm{ab}$ \\
Lamb's Summer & $0,18 \mathrm{c}$ & $0,14 \mathrm{~b}$ & $0,13 \mathrm{~b}$ & $0,15 \mathrm{bc}$ \\
Olimpia 15161 & $0,17 \mathrm{c}$ & $0,14 \mathrm{~b}$ & $0,13 \mathrm{~b}$ & $0,14 \mathrm{c}$ \\
Ovale 968 & $0,18 \mathrm{bc}$ & $0,15 \mathrm{~b}$ & $0,15 \mathrm{ab}$ & $0,16 \mathrm{bc}$ \\
Ovale San Lio 969 & $0,18 \mathrm{bc}$ & $0,15 \mathrm{~b}$ & $0,13 \mathrm{~b}$ & $0,16 \mathrm{bc}$ \\
Premunizada 1212 & $0,18 \mathrm{c}$ & $0,15 \mathrm{~b}$ & $0,13 \mathrm{~b}$ & $0,15 \mathrm{bc}$ \\
Premunizada 1743/82 & $0,18 \mathrm{c}$ & $0,15 \mathrm{~b}$ & $0,13 \mathrm{~b}$ & $0,15 \mathrm{bc}$ \\
R. Gullo 1569/244 & $0,17 \mathrm{c}$ & $0,14 \mathrm{~b}$ & $0,13 \mathrm{~b}$ & $0,14 \mathrm{c}$ \\
R. Gullo 1570/246 & $0,18 \mathrm{c}$ & $0,15 \mathrm{~b}$ & $0,12 \mathrm{~b}$ & $0,15 \mathrm{c}$ \\
Redonda C.N. & $0,22 \mathrm{ab}$ & $0,19 \mathrm{a}$ & $0,17 \mathrm{a}$ & $0,19 \mathrm{a}$ \\
Vimusa & $0,18 \mathrm{c}$ & $0,14 \mathrm{~b}$ & $0,13 \mathrm{~b}$ & $0,14 \mathrm{c}$ \\
\hline C.V. & $10,83 \%$ & $10,63 \%$ & $11,83 \%$ & $8,54 \%$ \\
\hline Vidins
\end{tabular}

Médias seguidas pela mesma letra não diferem significativamente pelo Teste de Tukey a $5 \%$.

Tabela 17. Espessura de três regiões (superior, mediana e inferior) e espessura média do epicarpo (cm), de quatro frutos de dez clones de laranjeira 'Pêra' e cinco variedades afins, em Cordeirópolis-SP, safra 2000.

\begin{tabular}{lcccc}
\hline Variedades & Superior & Mediana & Inferior & Média \\
\hline Bianchi & $0,14 \mathrm{bc}$ & $0,14 \mathrm{bc}$ & $0,12 \mathrm{~b}$ & $0,13 \mathrm{bc}$ \\
Corsa Tardia & $0,15 \mathrm{bc}$ & $0,16 \mathrm{ab}$ & $0,13 \mathrm{ab}$ & $0,15 \mathrm{~b}$ \\
Dibbern C.V. & $0,15 \mathrm{bc}$ & $0,15 \mathrm{bc}$ & $0,12 \mathrm{~b}$ & $0,14 \mathrm{bc}$ \\
EEL & $0,15 \mathrm{bc}$ & $0,14 \mathrm{bc}$ & $0,11 \mathrm{~b}$ & $0,13 \mathrm{bc}$ \\
GS 2000 & $0,17 \mathrm{ab}$ & $0,15 \mathrm{bc}$ & $0,12 \mathrm{~b}$ & $0,15 \mathrm{~b}$ \\
Lamb's Summer & $0,15 \mathrm{bc}$ & $0,16 \mathrm{bc}$ & $0,12 \mathrm{~b}$ & $0,14 \mathrm{bc}$ \\
Olimpia 15161 & $0,15 \mathrm{bc}$ & $0,15 \mathrm{bc}$ & $0,12 \mathrm{~b}$ & $0,14 \mathrm{bc}$ \\
Ovale 968 & $0,15 \mathrm{abc}$ & $0,15 \mathrm{bc}$ & $0,13 \mathrm{~b}$ & $0,14 \mathrm{bc}$ \\
Ovale San Lio 969 & $0,15 \mathrm{bc}$ & $0,15 \mathrm{bc}$ & $0,12 \mathrm{~b}$ & $0,14 \mathrm{bc}$ \\
Premunizada 1212 & $0,15 \mathrm{bc}$ & $0,14 \mathrm{bc}$ & $0,12 \mathrm{~b}$ & $0,14 \mathrm{bc}$ \\
Premunizada 1743/82 & $0,15 \mathrm{bc}$ & $0,14 \mathrm{bc}$ & $0,11 \mathrm{~b}$ & $0,14 \mathrm{bc}$ \\
R. Gullo 1569/244 & $0,14 \mathrm{c}$ & $0,13 \mathrm{c}$ & $0,11 \mathrm{~b}$ & $0,13 \mathrm{c}$ \\
R. Gullo 1570/246 & $0,15 \mathrm{bc}$ & $0,15 \mathrm{bc}$ & $0,12 \mathrm{~b}$ & $0,14 \mathrm{bc}$ \\
Redonda C.N. & $0,18 \mathrm{a}$ & $0,18 \mathrm{a}$ & $0,15 \mathrm{a}$ & $0,17 \mathrm{a}$ \\
Vimusa & $0,15 \mathrm{bc}$ & $0,15 \mathrm{bc}$ & $0,13 \mathrm{~b}$ & $0,14 \mathrm{bc}$ \\
\hline C.V. & $7,20 \%$ & $8,70 \%$ & $9,48 \%$ & $6,60 \%$ \\
\hline
\end{tabular}

Médias seguidas pela mesma letra não diferem significativamente pelo Teste de Tukey a $5 \%$. 
Tabela 18. Espessura de três regiões (superior, mediana e inferior) e espessura média do mesocarpo $(\mathrm{cm})$, de quatro frutos de dez clones de laranjeira 'Pêra' e cinco variedades afins, em Cordeirópolis-SP, safra 1999.

\begin{tabular}{lcccc}
\hline Variedades & Superior & Mediana & Inferior & Média \\
\hline Bianchi & $0,46 \mathrm{abc}$ & $0,27 \mathrm{~b}$ & $0,26 \mathrm{a}$ & $0,32 \mathrm{bcd}$ \\
Corsa Tardia & $0,55 \mathrm{ab}$ & $0,31 \mathrm{ab}$ & $0,26 \mathrm{a}$ & $0,37 \mathrm{ab}$ \\
Dibbern C.V. & $0,36 \mathrm{c}$ & $0,26 \mathrm{~b}$ & $0,20 \mathrm{a}$ & $0,27 \mathrm{~d}$ \\
EEL & $0,41 \mathrm{bc}$ & $0,24 \mathrm{~b}$ & $0,25 \mathrm{a}$ & $0,30 \mathrm{bcd}$ \\
GS 2000 & $0,60 \mathrm{a}$ & $0,36 \mathrm{a}$ & $0,29 \mathrm{a}$ & $0,41 \mathrm{a}$ \\
Lamb's Summer & $0,43 \mathrm{bc}$ & $0,26 \mathrm{~b}$ & $0,27 \mathrm{a}$ & $0,32 \mathrm{bcd}$ \\
Olímpia 15161 & $0,40 \mathrm{bc}$ & $0,31 \mathrm{ab}$ & $0,24 \mathrm{a}$ & $0,32 \mathrm{bcd}$ \\
Ovale 968 & $0,48 \mathrm{abc}$ & $0,29 \mathrm{ab}$ & $0,23 \mathrm{a}$ & $0,33 \mathrm{bcd}$ \\
Ovale San Lio 969 & $0,52 \mathrm{ab}$ & $0,30 \mathrm{ab}$ & $0,24 \mathrm{a}$ & $0,35 \mathrm{abc}$ \\
Premunizada 1212 & $0,48 \mathrm{abc}$ & $0,32 \mathrm{ab}$ & $0,25 \mathrm{a}$ & $0,35 \mathrm{abc}$ \\
Premunizada 1743/82 & $0,39 \mathrm{c}$ & $0,25 \mathrm{~b}$ & $0,24 \mathrm{a}$ & $0,29 \mathrm{~cd}$ \\
R. Gullo 1569/244 & $0,47 \mathrm{abc}$ & $0,24 \mathrm{~b}$ & $0,22 \mathrm{a}$ & $0,31 \mathrm{bcd}$ \\
R. Gullo 1570/246 & $0,45 \mathrm{abc}$ & $0,27 \mathrm{ab}$ & $0,25 \mathrm{a}$ & $0,32 \mathrm{bcd}$ \\
Redonda C.N. & $0,43 \mathrm{bc}$ & $0,28 \mathrm{ab}$ & $0,25 \mathrm{a}$ & $0,32 \mathrm{bcd}$ \\
Vimusa & $0,45 \mathrm{abc}$ & $0,26 \mathrm{~b}$ & $0,23 \mathrm{a}$ & $0,31 \mathrm{bcd}$ \\
\hline C.V. & $16,52 \%$ & $15,08 \%$ & $16,08 \%$ & $11,68 \%$ \\
\hline Médias seguidas pela mesma letra não diferem significativamente pelo Teste de Tukey a $5 \%$
\end{tabular}

Tabela 19. Espessura de três regiōes (superior, mediana e inferior) e espessura média do mesocarpo $(\mathrm{cm})$, de quatro frutos dez clones de laranjeira 'Pêra' e cinco variedades afins, em Cordeirópolis-SP, safra 2000.

\begin{tabular}{lcccc}
\hline Variedades & Superior & Mediana & Inferior & Média \\
\hline Bianchi & $0,38 \mathrm{abc}$ & $0,27 \mathrm{bc}$ & $0,23 \mathrm{~b}$ & $0,29 \mathrm{bcd}$ \\
Corsa Tardia & $0,47 \mathrm{abc}$ & $0,36 \mathrm{ab}$ & $0,26 \mathrm{ab}$ & $0,37 \mathrm{ab}$ \\
Dibbern C.V. & $0,44 \mathrm{abc}$ & $0,31 \mathrm{abc}$ & $0,24 \mathrm{ab}$ & $0,33 \mathrm{abcd}$ \\
EEL & $0,36 \mathrm{c}$ & $0,25 \mathrm{c}$ & $0,22 \mathrm{~b}$ & $0,27 \mathrm{~d}$ \\
GS 2000 & $0,51 \mathrm{a}$ & $0,33 \mathrm{abc}$ & $0,31 \mathrm{a}$ & $0,38 \mathrm{a}$ \\
Lamb's Summer & $0,48 \mathrm{abc}$ & $0,34 \mathrm{abc}$ & $0,26 \mathrm{ab}$ & $0,36 \mathrm{abc}$ \\
Olímpia 15161 & $0,42 \mathrm{abc}$ & $0,31 \mathrm{abc}$ & $0,25 \mathrm{ab}$ & $0,33 \mathrm{abcd}$ \\
Ovale 968 & $0,48 \mathrm{abc}$ & $0,37 \mathrm{a}$ & $0,23 \mathrm{~b}$ & $0,36 \mathrm{abc}$ \\
Ovale San Lio 969 & $0,49 \mathrm{abc}$ & $0,34 \mathrm{abc}$ & $0,21 \mathrm{~b}$ & $0,35 \mathrm{abcd}$ \\
Premunizada 1212 & $0,50 \mathrm{ab}$ & $0,36 \mathrm{ab}$ & $0,27 \mathrm{ab}$ & $0,38 \mathrm{a}$ \\
Premunizada 1743/82 & $0,43 \mathrm{abc}$ & $0,27 \mathrm{bc}$ & $0,23 \mathrm{~b}$ & $0,31 \mathrm{abcd}$ \\
R. Gullo 1569/244 & $0,37 \mathrm{bc}$ & $0,26 \mathrm{c}$ & $0,22 \mathrm{~b}$ & $0,28 \mathrm{~cd}$ \\
R. Gullo 1570/246 & $0,43 \mathrm{abc}$ & $0,28 \mathrm{bc}$ & $0,23 \mathrm{~b}$ & $0,32 \mathrm{abcd}$ \\
Redonda C.N. & $0,41 \mathrm{abc}$ & $0,36 \mathrm{ab}$ & $0,31 \mathrm{a}$ & $0,36 \mathrm{abc}$ \\
Vimusa & $0,50 \mathrm{ab}$ & $0,32 \mathrm{abc}$ & $0,26 \mathrm{ab}$ & $0,36 \mathrm{abc}$ \\
\hline C.V. & $14,47 \%$ & $14,33 \%$ & $15,17 \%$ & $12,19 \%$ \\
\hline
\end{tabular}

Médias seguidas pela mesma letra não diferem significativamente pelo Teste de Tukey a $5 \%$. 
Tabela 20. Espessura de três regiões (superior, mediana e inferior) e espessura média da casca $(\mathrm{cm})$, de quatro frutos de dez clones de laranjeira 'Pêra' e cinco variedades afins, em Cordeirópolis-SP, safra 1999.

\begin{tabular}{lcccc}
\hline Variedades & Superior & Mediana & Inferior & Média \\
\hline Bianchi & $0,64 \mathrm{bc}$ & $0,42 \mathrm{ab}$ & $0,38 \mathrm{ab}$ & $0,48 \mathrm{bc}$ \\
Corsa Tardia & $0,72 \mathrm{ab}$ & $0,47 \mathrm{ab}$ & $0,40 \mathrm{ab}$ & $0,53 \mathrm{ab}$ \\
Dibbern C.V. & $0,54 \mathrm{c}$ & $0,41 \mathrm{~b}$ & $0,32 \mathrm{~b}$ & $0,42 \mathrm{c}$ \\
EEL & $0,60 \mathrm{bc}$ & $0,40 \mathrm{~b}$ & $0,39 \mathrm{ab}$ & $0,46 \mathrm{bc}$ \\
GS 2000 & $0,83 \mathrm{a}$ & $0,52 \mathrm{a}$ & $0,42 \mathrm{a}$ & $0,59 \mathrm{a}$ \\
Lamb's Summer & $0,61 \mathrm{bc}$ & $0,41 \mathrm{~b}$ & $0,39 \mathrm{ab}$ & $0,47 \mathrm{bc}$ \\
Olimpia 15161 & $0,57 \mathrm{bc}$ & $0,45 \mathrm{ab}$ & $0,36 \mathrm{ab}$ & $0,46 \mathrm{bc}$ \\
Ovale 968 & $0,66 \mathrm{bc}$ & $0,45 \mathrm{ab}$ & $0,38 \mathrm{ab}$ & $0,50 \mathrm{bc}$ \\
Ovale San Lio 969 & $0,70 \mathrm{abc}$ & $0,46 \mathrm{ab}$ & $0,37 \mathrm{ab}$ & $0,51 \mathrm{abc}$ \\
Premunizada 1212 & $0,66 \mathrm{bc}$ & $0,47 \mathrm{ab}$ & $0,38 \mathrm{ab}$ & $0,50 \mathrm{abc}$ \\
Premunizada 1743/82 & $0,57 \mathrm{bc}$ & $0,40 \mathrm{~b}$ & $0,36 \mathrm{ab}$ & $0,44 \mathrm{bc}$ \\
R. Gullo 1569/244 & $0,63 \mathrm{bc}$ & $0,38 \mathrm{~b}$ & $0,35 \mathrm{ab}$ & $0,45 \mathrm{bc}$ \\
R. Gullo 1570/246 & $0,63 \mathrm{bc}$ & $0,42 \mathrm{~b}$ & $0,37 \mathrm{ab}$ & $0,47 \mathrm{bc}$ \\
Redonda C.N. & $0,65 \mathrm{bc}$ & $0,47 \mathrm{ab}$ & $0,42 \mathrm{a}$ & $0,51 \mathrm{ab}$ \\
Vimusa & $0,62 \mathrm{bc}$ & $0,40 \mathrm{~b}$ & $0,35 \mathrm{ab}$ & $0,46 \mathrm{bc}$ \\
\hline C.V. & $12,73 \%$ & $10,69 \%$ & $11,24 \%$ & $9,07 \%$ \\
\hline
\end{tabular}

Médias seguidas pela mesma letra não diferem significativamente pelo Teste de Tukey a 5\%.

Tabela 21. Espessura de três regiões (superior, mediana e inferior) e espessura média da casca $(\mathrm{cm})$, de quatro frutos de dez clones de laranjeira 'Pêra' e cinco variedades afins, em Cordeirópolis-SP, safra 2000.

\begin{tabular}{lcccc}
\hline Variedades s & Superior & Mediana & Inferior & Média \\
\hline Bianchi & $0,52 \mathrm{bc}$ & $0,41 \mathrm{~cd}$ & $0,35 \mathrm{c}$ & $0,42 \mathrm{bc}$ \\
Corsa Tardia & $0,62 \mathrm{abc}$ & $0,52 \mathrm{ab}$ & $0,39 \mathrm{abc}$ & $0,51 \mathrm{ab}$ \\
Dibbern C.V. & $0,59 \mathrm{abc}$ & $0,46 \mathrm{abcd}$ & $0,36 \mathrm{c}$ & $0,47 \mathrm{abc}$ \\
EEL & $0,50 \mathrm{c}$ & $0,39 \mathrm{~d}$ & $0,33 \mathrm{c}$ & $0,41 \mathrm{c}$ \\
GS 2000 & $0,67 \mathrm{a}$ & $0,48 \mathrm{abcd}$ & $0,43 \mathrm{ab}$ & $0,53 \mathrm{a}$ \\
Lamb's Summer & $0,63 \mathrm{abc}$ & $0,49 \mathrm{abc}$ & $0,39 \mathrm{abc}$ & $0,50 \mathrm{ab}$ \\
Olimpia 15161 & $0,57 \mathrm{abc}$ & $0,46 \mathrm{abcd}$ & $0,37 \mathrm{bc}$ & $0,47 \mathrm{abc}$ \\
Ovale 968 & $0,63 \mathrm{abc}$ & $0,52 \mathrm{ab}$ & $0,35 \mathrm{c}$ & $0,50 \mathrm{ab}$ \\
Ovale San Lio 969 & $0,64 \mathrm{abc}$ & $0,48 \mathrm{abcd}$ & $0,33 \mathrm{c}$ & $0,49 \mathrm{abc}$ \\
Premunizada 1212 & $0,65 \mathrm{ab}$ & $0,50 \mathrm{abc}$ & $0,39 \mathrm{abc}$ & $0,51 \mathrm{ab}$ \\
Premunizada 1743/82 & $0,58 \mathrm{abc}$ & $0,41 \mathrm{~cd}$ & $0,34 \mathrm{c}$ & $0,44 \mathrm{abc}$ \\
R. Gullo 1569/244 & $0,51 \mathrm{bc}$ & $0,39 \mathrm{~d}$ & $0,32 \mathrm{c}$ & $0,41 \mathrm{c}$ \\
R. Gullo 1570/246 & $0,58 \mathrm{abc}$ & $0,43 \mathrm{bcd}$ & $0,34 \mathrm{c}$ & $0,45 \mathrm{abc}$ \\
Redonda C.N. & $0,59 \mathrm{abc}$ & $0,54 \mathrm{a}$ & $0,46 \mathrm{a}$ & $0,53 \mathrm{a}$ \\
Vimusa & $0,64 \mathrm{ab}$ & $0,47 \mathrm{abcd}$ & $0,39 \mathrm{abc}$ & $0,50 \mathrm{ab}$ \\
\hline C.V. & $11,45 \%$ & $10,65 \%$ & $11,54 \%$ & $9,43 \%$ \\
\hline
\end{tabular}

Médias seguidas pela mesma letra não diferem significativamente pelo Teste de Tukey a $5 \%$. 


\subsection{Características internas dos frutos}

\subsubsection{Rendimento de suco}

Quanto ao rendimento médio de suco, não houve diferenças entre os dez clones de laranjeira 'Pêra' e as cinco variedades afins, para o ano de 1999, mas observam-se diferenças significativas, para o ano 2000 (Tabela 22).

No primeiro ano de avaliação a análise de qualidade de suco foi realizada em 5 de outubro, e no segundo ano, em 21 de setembro. Além disso, para a safra de 2000 , as plantas praticamente perderam a primeira florada devido às condições climáticas, tendo outras duas floradas consecutivas. Consequentemente, na safra de 2000 , os frutos não atingiram o mesmo estágio de maturação de 1999 , explicando o menor rendimento de suco obtido em 2000.

Tabela 22. Rendimento médio de suco (\%), de dez frutos de dez clones de laranjeira 'Pêra' e cinco variedades afins, em Cordeirópolis-SP, safras 1999 e 2000.

\begin{tabular}{lcc}
\hline Variedades & \multicolumn{2}{c}{ Rendimento de suco (1999) } \\
\hline & \multicolumn{2}{c}{ Rendimento de suco (2000) } \\
\cline { 2 - 3 } Bianchi & 48,72 & $45,28 \mathrm{ab}$ \\
Corsa Tardia & 51,57 & $38,02 \mathrm{~b}$ \\
Dibbern C.V. & 51,75 & $46,22 \mathrm{ab}$ \\
EEL & 52,67 & $45,87 \mathrm{ab}$ \\
GS 2000 & 51,02 & $43,87 \mathrm{ab}$ \\
Lamb's Summer & 47,62 & $43,70 \mathrm{ab}$ \\
Olímpia 15161 & 51,88 & $48,98 \mathrm{a}$ \\
Ovale 968 & 53,72 & $47,30 \mathrm{ab}$ \\
Ovale San Lio 969 & 55,08 & $43,47 \mathrm{ab}$ \\
Premunizada 1212 & 50,43 & $48,00 \mathrm{a}$ \\
Premunizada 1743/82 & 51,88 & $41,33 \mathrm{ab}$ \\
R. Gullo 1569/244 & 53,12 & $46,65 \mathrm{ab}$ \\
R. Gullo 1570/246 & 50,40 & $46,22 \mathrm{ab}$ \\
Redonda C.N. & 52,65 & $49,90 \mathrm{a}$ \\
Vimusa & 51,80 & $46,00 \mathrm{ab}$ \\
\hline C.V. & $6,66 \%$ & $10,25 \%$ \\
\hline
\end{tabular}

Médias seguidas pela mesma letra não diferem significativamente pelo Teste de Tukey a 5\%. 
Teófilo Sobrinho et al. (1996) e Teófilo Sobrinho et al. (1992) encontraram menores valores de porcentagem de rendimento de suco para a variedade afim Lamb's Summer, na região de Araraquara-SP e Limeira-SP, respectivamente. No ano de 2000, a variedade afim Redonda C.N. e o clone de laranjeira 'Pêra' Premunizada 1212 apresentaram maiores porcentagens de rendimento de suco, com $49,90 \%$ e 48,00\%, respectivamente, diferindo estatisticamente da variedade afim Corsa Tardia, que apresentou um rendimento de suco de $38,02 \%$.

\subsubsection{Sólidos solúveis $\left({ }^{\circ}\right.$ Brix $)$}

Houve diferenças significativas entre os dez clones de laranjeira 'Pêra' e as cinco variedades afins quanto aos teores médios de sólidos solúveis dados em ${ }^{\circ} \mathrm{Brix}$ (Tabela 23)

Não houve correlação da severidade da doença com os teores médios de sólidos solúveis dos frutos para as variedades estudadas, nos anos de 1999 e 2000. Entretanto, na África do Sul, é citado que os frutos infectados possuem maiores teores de sólidos solúveis (Goes, 1998).

O clone de 'Pêra' R. Gullo $1570 / 246$ e a variedade afim Ovale 968, apresentaram o maior e o menor teor sólidos solúveis, com $14,55^{\circ} \mathrm{Brix}$ e $10,97{ }^{\circ} \mathrm{Brix}$, respectivamente para o ano de 1999. Em 2000, a variedade afim Lamb's Summer obteve o maior teor de sólidos solúveis, com 14,13 ${ }^{\circ}$ Brix e a 'Pêra' Olímpia 15161 o menor, $\operatorname{com} 12,77^{\circ}$ Brix. 
Tabela 23. Sólidos solúveis ('Brix), de dez frutos de dez clones de laranjeira 'Pêra' e cinco variedades afins, em Cordeirópolis-SP, safras 1999 e 2000.

\begin{tabular}{lcc}
\hline Variedades & Sólidos solúveis (1999) & Sólidos solúveis (2000) \\
\hline & \multicolumn{3}{c}{${ }^{\circ}$ Brix } \\
\cline { 2 - 3 } Bianchi & $12,58 \mathrm{abcd}$ & $13,58 \mathrm{abc}$ \\
Corsa Tardia & $11,08 \mathrm{~d}$ & $13,45 \mathrm{abc}$ \\
Dibbern C.V. & $12,77 \mathrm{abcd}$ & $13,30 \mathrm{abc}$ \\
EEL & $12,67 \mathrm{abcd}$ & $13,45 \mathrm{abc}$ \\
GS 2000 & $13,30 \mathrm{abc}$ & $13,53 \mathrm{abc}$ \\
Lamb's Summer & $13,68 \mathrm{abc}$ & $14,13 \mathrm{a}$ \\
Olímpia 15161 & $12,90 \mathrm{abcd}$ & $12,77 \mathrm{c}$ \\
Ovale 968 & $10,97 \mathrm{~d}$ & $13,03 \mathrm{bc}$ \\
Ovale San Lio 969 & $11,72 \mathrm{~cd}$ & $13,53 \mathrm{abc}$ \\
Premunizada 1212 & $13,70 \mathrm{abc}$ & $13,85 \mathrm{ab}$ \\
Premunizada 1743/82 & $12,85 \mathrm{abcd}$ & $13,52 \mathrm{abc}$ \\
R. Gullo 1569/244 & $13,80 \mathrm{ab}$ & $13,77 \mathrm{ab}$ \\
R. Gullo 1570/246 & $14,55 \mathrm{a}$ & $13,67 \mathrm{ab}$ \\
Redonda C.N. & $12,32 \mathrm{bcd}$ & $13,47 \mathrm{abc}$ \\
Vimusa & $13,25 \mathrm{abc}$ & $13,30 \mathrm{abc}$ \\
\hline C.V. & $7,58 \%$ & $3,23 \%$ \\
\hline
\end{tabular}

Médias seguidas pela mesma letra não diferem significativamente pelo Teste de Tukey a $5 \%$.

\subsubsection{Acidez total}

Os clones de laranjeira 'Pêra' diferiram entre si quanto à acidez total do suco (Tabela 24). Não houve correlação da severidade da doença com a porcentagem de acidez total dos frutos, para as variedades estudadas, nos anos de 1999 e 2000.

A variedade afim Lamb's Summer apresentou maiores porcentagens de acidez total para os dois anos consecutivos de avaliação, parecendo ser de maturação mais tardia que as demais seleções estudadas e estando de acordo com os dados obtidos por Teófilo Sobrinho et al. (1996), na regiâo de Araraquara-SP e Teófilo Sobrinho et al. (1992), na região de Limeira-SP. A variedade afim Corsa tardia e a 'Pêra' Olímpia 15161 apresentaram menores porcentagens de acidez total, para os anos de 1999 e 2000, respectivamente. 
Tabela 24. Acidez total (\%), de dez frutos de dez clones de laranjeira 'Pêra' e cinco variedades afins, em Cordeirópolis-SP, safras 1999 e 2000.

\begin{tabular}{lcc}
\hline Variedades & Acidez total (1999) & Acidez total (2000) \\
\hline & & $\%$ \\
Bianchi & $0,88 \mathrm{cde}$ & $1,48 \mathrm{~b}$ \\
Corsa Tardia & $0,67 \mathrm{e}$ & $1,62 \mathrm{~b}$ \\
Dibbern C.V. & $0,89 \mathrm{cde}$ & $1,68 \mathrm{~b}$ \\
EEL & $0,78 \mathrm{de}$ & $1,62 \mathrm{~b}$ \\
GS 2000 & $1,00 \mathrm{~cd}$ & $1,50 \mathrm{~b}$ \\
Lamb's Summer & $1,30 \mathrm{ab}$ & $2,16 \mathrm{a}$ \\
Olimpia 15161 & $0,86 \mathrm{de}$ & $1,44 \mathrm{~b}$ \\
Ovale 968 & $0,85 \mathrm{de}$ & $1,88 \mathrm{ab}$ \\
Ovale San Lio 969 & $0,80 \mathrm{de}$ & $1,64 \mathrm{~b}$ \\
Premunizada 1212 & $0,87 \mathrm{cde}$ & $1,74 \mathrm{ab}$ \\
Premunizada 1743/82 & $0,96 \mathrm{~cd}$ & $1,53 \mathrm{~b}$ \\
R. Gullo 1569/244 & $1,02 \mathrm{bcd}$ & $1,57 \mathrm{~b}$ \\
R. Gullo 1570/246 & $1,03 \mathrm{bcd}$ & $1,65 \mathrm{~b}$ \\
Redonda C.N. & $1,14 \mathrm{abc}$ & $1,77 \mathrm{ab}$ \\
Vimusa & $0,97 \mathrm{~cd}$ & $1,57 \mathrm{~b}$ \\
\hline C.V. & $14,34 \%$ & $14,24 \%$ \\
\hline
\end{tabular}

Médias seguidas pela mesma letra não diferem significativamente pelo Teste de Tukey a 5\%.

Segundo Di Giorgi et al. (1994), para a variedade 'Pêra', os frutos são colhidos normalmente com níveis de acidez entre 0,6 a $0,9 \%$, conseguindo-se nesse estágio maiores valores de ${ }^{\circ}$ Brix e menores índices de degradação dos frutos que acarreta a perda do seu valor comercial tanto como fruto para mesa como para o processamento na indústria. Portanto, na época de avaliação das qualidades internas dos frutos (5 de outubro), no ano de 1999, quase todas as variedades estavam dentro dos padrões estabelecidos para a colheita. Entretanto, no ano 2000, todas as variedades ainda não tinham atingido o ponto ideal para a colheita, estando com a acidez muito alta, pois além dos frutos serem analisados em 21 de setembro, 14 dias antes da análise feita em 1999, as plantas perderam a primeira florada para o ano de 2000 , o que atrasou a maturação dos frutos. 


\subsubsection{Relação sólidos solúveis: acidez (ratio)}

Houve diferenças significativas entre os clones de laranjeira 'Pêra' e as variedades afins para a relação sólidos solúveis:acidez (ratio) (Tabela 25). Não houve correlação da severidade da doença com o ratio dos frutos, para as variedades estudadas, nos anos de 1999 e 2000.

A variedade afim Corsa Tardia obteve maior ratio em 1999, e os clones de laranjeira 'Pêra' GS 2000 e Bianchi obtiveram maior ratio em 2000. A variedade afim Lamb's Summer apresentou menor ratio nos dois anos consecutivos de avaliação, estando de acordo com Teófilo Sobrinho et al. (1996). Pode-se observar também que as variedaddes afins Redonda C.N. e Lamb's Summer, com menor ratio, foram os que obtiveram maiores percentagens de acidez total, para o ano de 1999.

Tabela 25. Relação sólidos solúveis:acidez (ratio) de dez frutos de dez clones de laranjeira 'Pêra' e cinco variedades afins, em Cordeirópolis-SP, safras 1999 e 2000.

\begin{tabular}{lcc}
\hline Variedades & Ratio (1999) & Ratio (2000) \\
\hline Bianchi & $14,67 \mathrm{ab}$ & $9,27 \mathrm{a}$ \\
Corsa Tardia & $16,62 \mathrm{a}$ & $8,32 \mathrm{ab}$ \\
Dibbern C.V. & $14,40 \mathrm{abcd}$ & $8,20 \mathrm{ab}$ \\
EEL & $16,58 \mathrm{a}$ & $8,58 \mathrm{ab}$ \\
GS 2000 & $13,33 \mathrm{abcd}$ & $9,27 \mathrm{a}$ \\
Lamb's Summer & $10,60 \mathrm{~d}$ & $6,60 \mathrm{~b}$ \\
Olimpia 15161 & $15,35 \mathrm{a}$ & $9,17 \mathrm{a}$ \\
Ovale 968 & $12,95 \mathrm{abcd}$ & $7,00 \mathrm{ab}$ \\
Ovale San Lio 969 & $14,93 \mathrm{a}$ & $8,23 \mathrm{ab}$ \\
Premunizada 1212 & $16,13 \mathrm{a}$ & $8,05 \mathrm{ab}$ \\
Premunizada 1743/82 & $13,58 \mathrm{abcd}$ & $8,90 \mathrm{ab}$ \\
R. Gullo 1569/244 & $13,63 \mathrm{abcd}$ & $8,95 \mathrm{ab}$ \\
R. Gullo 1570/246 & $14,47 \mathrm{abc}$ & $8,45 \mathrm{ab}$ \\
Redonda C.N. & $10,83 \mathrm{~cd}$ & $7,67 \mathrm{ab}$ \\
Vimusa & $13,75 \mathrm{abcd}$ & $8,60 \mathrm{ab}$ \\
\hline C.V. & $13,25 \%$ & $14,53 \%$ \\
\hline
\end{tabular}

Médias seguidas pela mesma letra não diferem significativamente pelo Teste de Tukey a 5\%. 
Segundo Viégas (1991), os valores ideais de ratio para a industrialização estão na faixa compreendida entre 11 e 14, pois nesses níveis, a acide $z$ ainda é adequada para manter a qualidade e a conservação do suco após o processamento. Portanto, na época de avaliação das qualidades internas dos frutos, no ano de 1999 , quase todas as variedades estavam dentro dos padrões estabelecidos para a colheita, com valores próximos e até acima do ideal. Entretanto, no ano 2000, todas as variedades ainda não tinham atingido o ponto ideal para a colheita, pois o suco não tinha atingido um ratio com os niveis ideais estabelecidos para a industrialização.

\subsection{5 Índice tecnológico ( $\mathrm{kg}$ sólidos solúveis por caixa)}

Os clones de 'Pêra' R. Gullo 1569/244 e R. Gullo 1570/246 apresentaram maior índice tecnológico, ambos com $2,99 \mathrm{~kg}$ de sólidos solúveis por caixa, e a variedade afim Corsa Tardia obteve menor índice tecnológico, com $2,34 \mathrm{~kg}$ de sólidos solúveis por caixa, na safra de 1999 (Tabela 26). Para a safra de 2000 , a variedade afim Ovale San Lio 969 obteve maior indice tecnológico, com $2,74 \mathrm{~kg}$ de sólidos solúveis por caixa, e a variedade afim Ovale 968 , com menor índice tecnológico $(2,08)$.

Domingues et al. (1997), analisando os clones de laranjeira 'Pêra', na mesma área experimental do presente trabalho, quando as plantas estavam com quinze anos de idade, obtiveram maior índice tecnológico para o clone de 'Pêra' Premunizada 1212, com 2,60 kg e o menor para o clone de 'Pêra' GS 2000, que alcançou apenas $2,10 \mathrm{~kg}$ de sólidos solúveis por caixa.

Teófilo Sobrinho et al. (1992), avaliando quinze clones de laranjeira 'Pêra' na região de Limeira, obtiveram maior indice tecnológico para a 'Pêra' R. Gullo 1569/244, com $2,49 \mathrm{~kg}$ e apenas $2,03 \mathrm{~kg}$ de sólidos solúveis por caixa para a variedade afim Lamb's Sammer. 
Tabela 26. Índice tecnológico ( $\mathrm{kg}$ de sólidos solúveis/cx), de dez clones de laranjeira 'Pêra' e cinco variedades afins, em Cordeirópolis-SP, safras 1999 e 2000.

\begin{tabular}{lcc}
\hline Variedades & Indice tecnológico (1999) & Indice tecnológico (2000) \\
\cline { 2 - 3 } Bianchi & \multicolumn{1}{c}{ Kg de sólidos solúveis/cx } \\
\cline { 2 - 3 } Corsa Tardia & $2,49 \mathrm{abc}$ & $2,40 \mathrm{ab}$ \\
Dibbern C.V. & $2,34 \mathrm{c}$ & $2,57 \mathrm{ab}$ \\
EEL & $2,69 \mathrm{abc}$ & $2,51 \mathrm{ab}$ \\
GS 2000 & $2,72 \mathrm{abc}$ & $2,55 \mathrm{ab}$ \\
Lamb's Summer & $2,77 \mathrm{abc}$ & $2,43 \mathrm{ab}$ \\
Olímpia 15161 & $2,66 \mathrm{abc}$ & $2,51 \mathrm{ab}$ \\
Ovale 968 & $2,73 \mathrm{abc}$ & $2,49 \mathrm{ab}$ \\
Ovale San Lio 969 & $2,40 \mathrm{bc}$ & $2,08 \mathrm{~b}$ \\
Premunizada 1212 & $2,63 \mathrm{abc}$ & $2,74 \mathrm{a}$ \\
Premunizada 1743/82 & $2,82 \mathrm{abc}$ & $2,71 \mathrm{a}$ \\
R. Gullo 1569/244 & $2,71 \mathrm{abc}$ & $2,27 \mathrm{ab}$ \\
R. Gullo 1570/246 & $2,99 \mathrm{a}$ & $2,57 \mathrm{ab}$ \\
Redonda C.N. & $2,99 \mathrm{a}$ & $2,61 \mathrm{a}$ \\
Vimusa & $2,65 \mathrm{abc}$ & $2,50 \mathrm{ab}$ \\
\hline C.V. & $2,80 \mathrm{abc}$ & $2,52 \mathrm{ab}$ \\
\hline Médias seguidas pela mesma letra não diferem significativamente pelo Teste de Tukey a $5 \%$ \\
'cx $=40,8$ kg.
\end{tabular}

\subsection{Porcentagem de luz no interior das plantas}

Quanto à porcentagem de luz no interior das plantas, houve diferenças significativas entre os clones de laranjeira 'Pêra' e as variedades afins (Tabela 27), estando a 'Pêra' Premunizada 1212 com uma maior penetração de luz em seu interior, ou seja, mais depauperada em relação as outras.

Não houve uma correlação da porcentagem de luz com a severidade dos sintomas da MPC, portanto, plantas que estavam menos enfolhadas, como as de 'Pêra' Premunizada 1212, não apresentaram os maiores índices de severidade da doença, não estando de acordo com Kotzé (1981), em que frutos expostos à maior luminosidade, apresentam maiores índices de severidade da doença, entretanto, pode-se salientar que a maior luminosidade deva estar relacionada à manifestação dos sintomas.

A porcentagem de luz no interior das plantas tem uma forte correlação com a média total do número de folhas caídas, nas duas avaliações realizadas em agosto e 
setembro de 2000, com coeficientes de determinação iguais a 0,67 e 0,75 , respectivamente, e $\mathrm{P}<0,05$. Com estes resultados, pode-se salientar que com o uso de um quantômetro, consegue-se estimar a queda de folhas de um pomar.

Tabela 27. Porcentagem de luz no interior das plantas de dez clones de laranjeira 'Pêra' e cinco variedades afins, mensurada com o auxílio de um quantômetro, em Cordeirópolis-SP, safra 2000.

\begin{tabular}{lcc}
\hline Variedades & Agosto & Setembro \\
\hline Bianchi & $8,27 \mathrm{abc}$ & $3,11 \mathrm{bcd}$ \\
Corsa Tardia & $5,00 \mathrm{c}$ & $1,83 \mathrm{~cd}$ \\
Dibbern C.V. & $5,62 \mathrm{bc}$ & $2,72 \mathrm{bcd}$ \\
EEL & $4,99 \mathrm{bc}$ & $1,94 \mathrm{bcd}$ \\
GS 2000 & $8,97 \mathrm{abc}$ & $4,44 \mathrm{abc}$ \\
Lamb's Summer & $6,49 \mathrm{bc}$ & $2,65 \mathrm{bcd}$ \\
Olimpia 15161 & $7,41 \mathrm{abc}$ & $3,18 \mathrm{bcd}$ \\
Ovale 968 & $5,00 \mathrm{bc}$ & $2,35 \mathrm{bcd}$ \\
Ovale San Lio 969 & $4,77 \mathrm{c}$ & $2,32 \mathrm{bcd}$ \\
Premium 1212 & $16,40 \mathrm{a}$ & $6,78 \mathrm{a}$ \\
Premunizada 1743/82 & $7,29 \mathrm{bc}$ & $3,42 \mathrm{bcd}$ \\
R. Gullo 1569/244 & $8,69 \mathrm{abc}$ & $4,22 \mathrm{abc}$ \\
R. Gullo 1570/246 & $13,95 \mathrm{ab}$ & $4,45 \mathrm{ab}$ \\
Redonda C.N. & $4,31 \mathrm{c}$ & $1,41 \mathrm{~d}$ \\
Vimusa & $4,79 \mathrm{bc}$ & $2,19 \mathrm{bcd}$ \\
\hline
\end{tabular}




\section{CONCLUSÕES}

Para os dez clones de laranjeira 'Pêra' e as cinco variedades afins, nas condições experimentais:

- Não houve diferenças significativas quanto à quantificação da incidência e severidade da Mancha Preta dos Citros no campo, e à densidade de colonização natural das folhas.

- Houve diferenças significativas na capacidade de crescimento de G. citricarpa em folhas em decomposição, e na densidade de corpos de frutificação in vitro.

- A incidência e a severidade dos sintomas da doença nos frutos é maior na parte baixa das plantas, até $1 \mathrm{~m}$, e menor acima de 2 metros de altura.

- Não houve correlação das características externas dos frutos como coloração da casca, formato, forma da base, forma do ápice, ângulo e achatamento da região basal e espessura da casca, do mesocarpo e do epicarpo, com a severidade da doença.

- A Mancha Preta dos Citros não interferiu nas qualidades organolépticas dos frutos.

- Houve diferenças significativas quanto ao desenvolvimento vegetativo e porcentagem de luz no interior das plantas; produção, cor da casca, relação altura/largura, massa e espessura da casca, do epicarpo e do mesocarpo dos frutos; rendimento de suco, sólidos solúveis, acidez total, ratio e índice tecnológico.

- Não houve diferenças significativas quanto ao ângulo e achatamento da região basal do fruto. 
ANEXOS 
Anexo A: Curva anual da média de folhas caídas em $1 \mathrm{~m}^{2}$, para cada clone de laranjeira 'Pêra' e variedade afim, obtida quinzenalmente de agosto de 1999 a dezembro de 2000, em Cordeirópolis-SP.
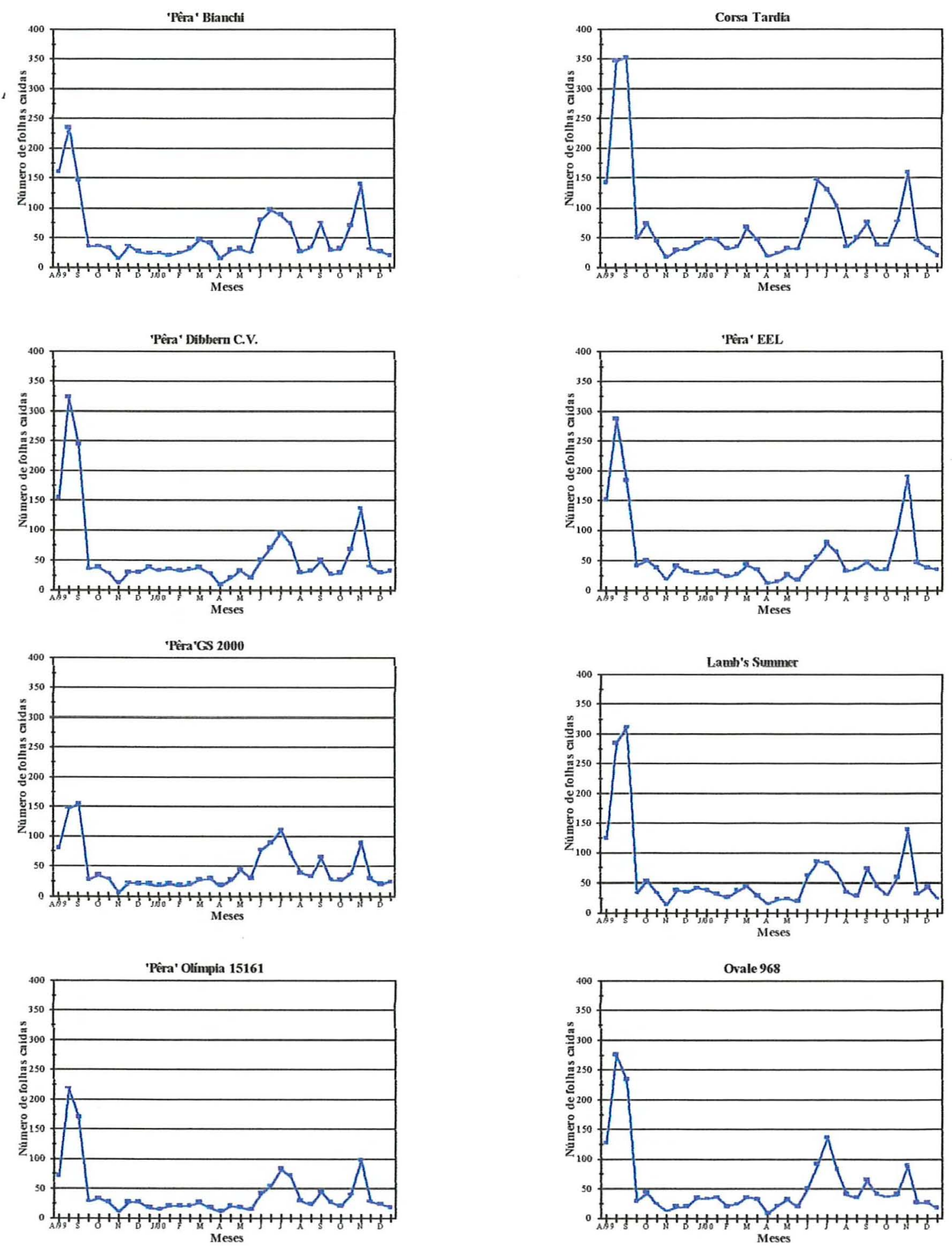

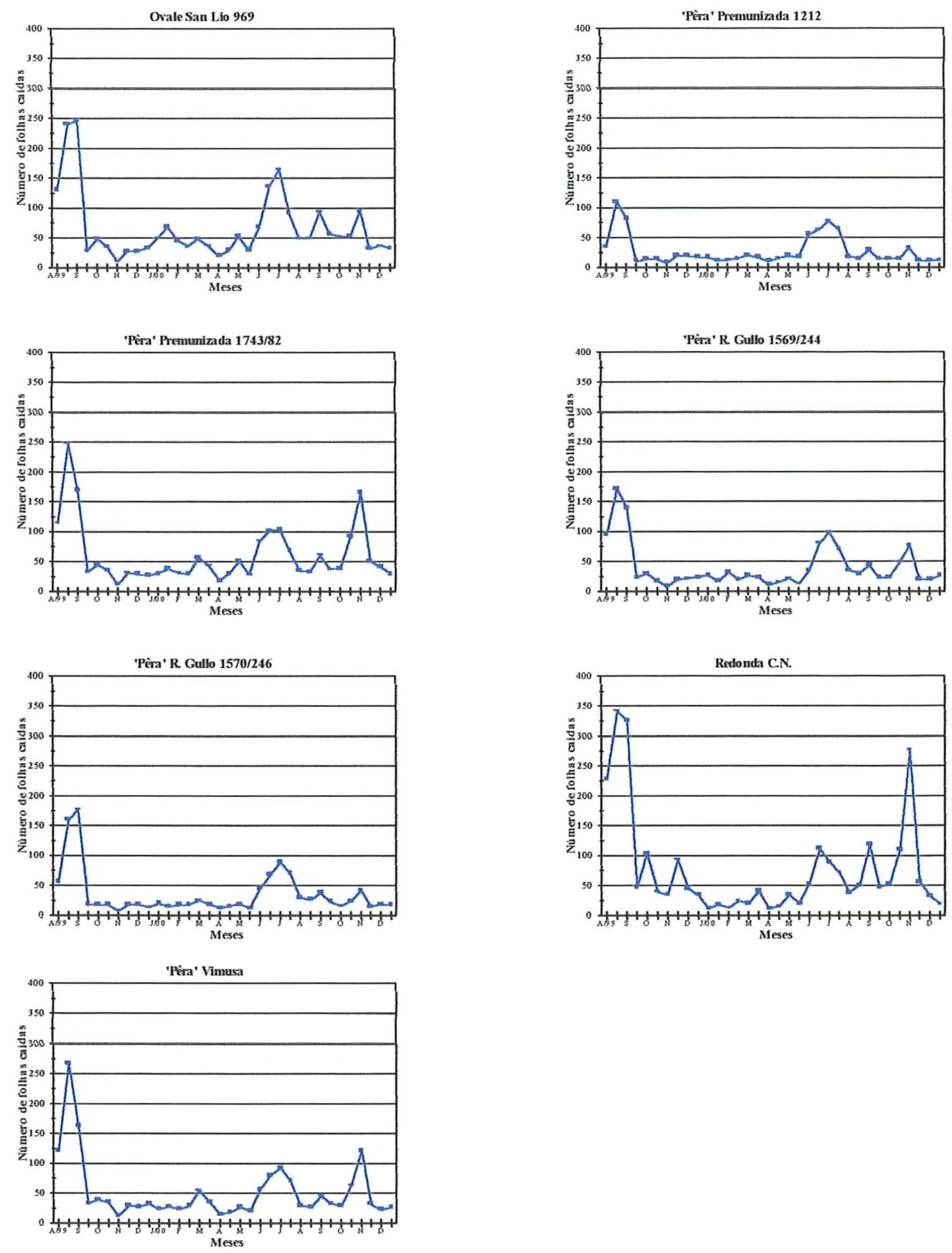
Anexo B: Curva anual da média de folhas caídas em $1 \mathrm{~m}^{2}$, para cada clone de laranjeira 'Pêra' e variedade afim estudados, obtida mensalmente de agosto de 1999 a dezembro de 2000, em Cordeirópolis-SP.

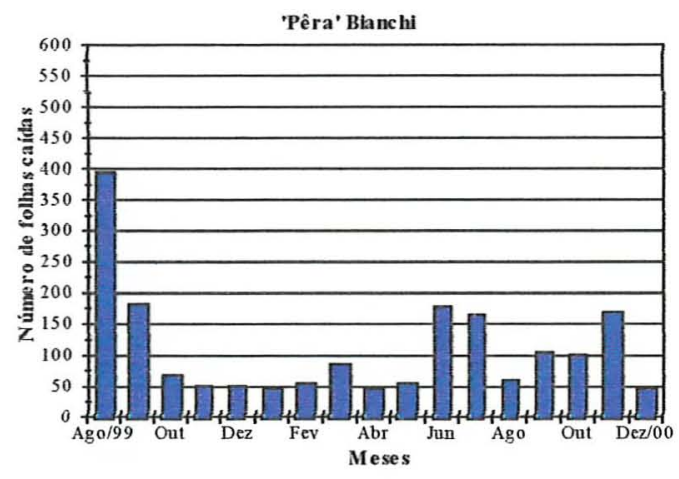

'Pêra' Dibbern C.V.
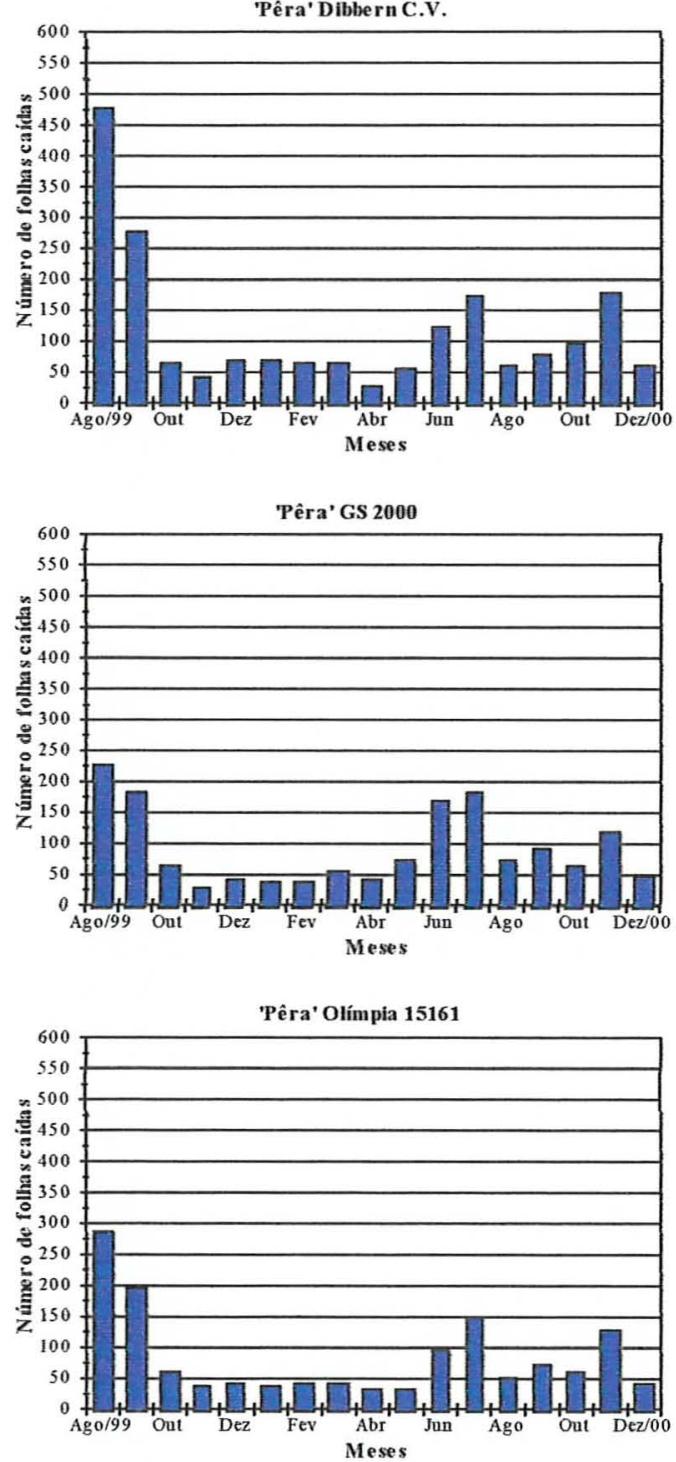
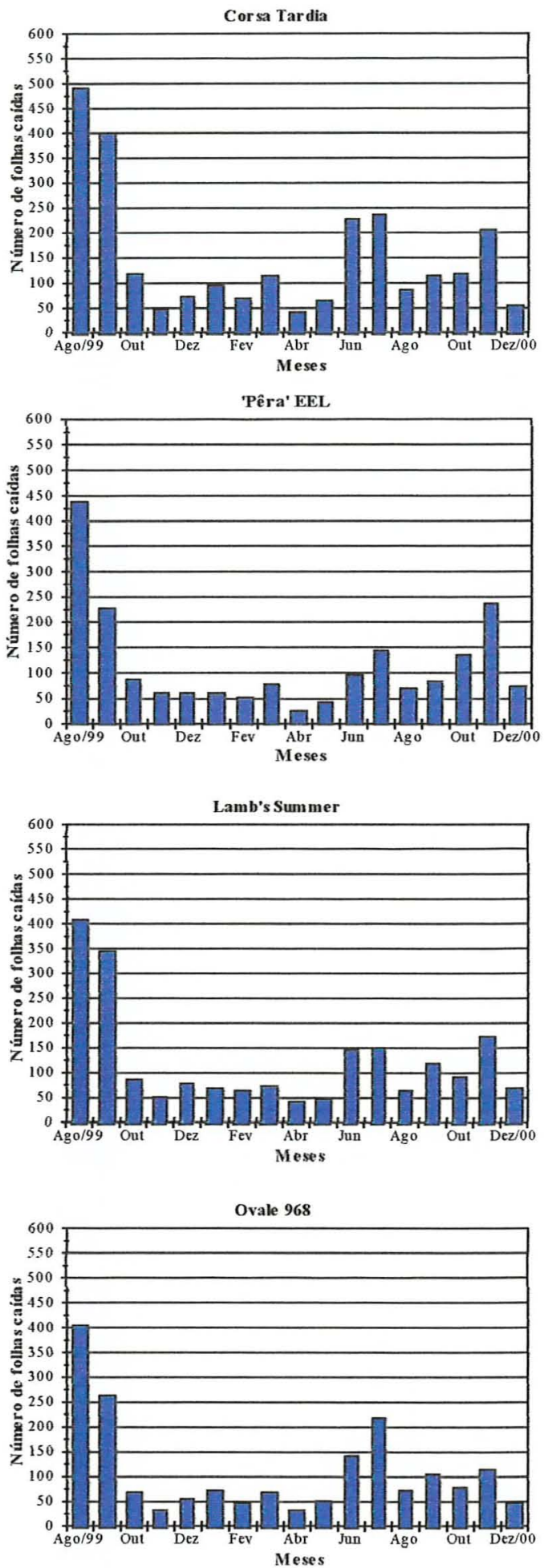

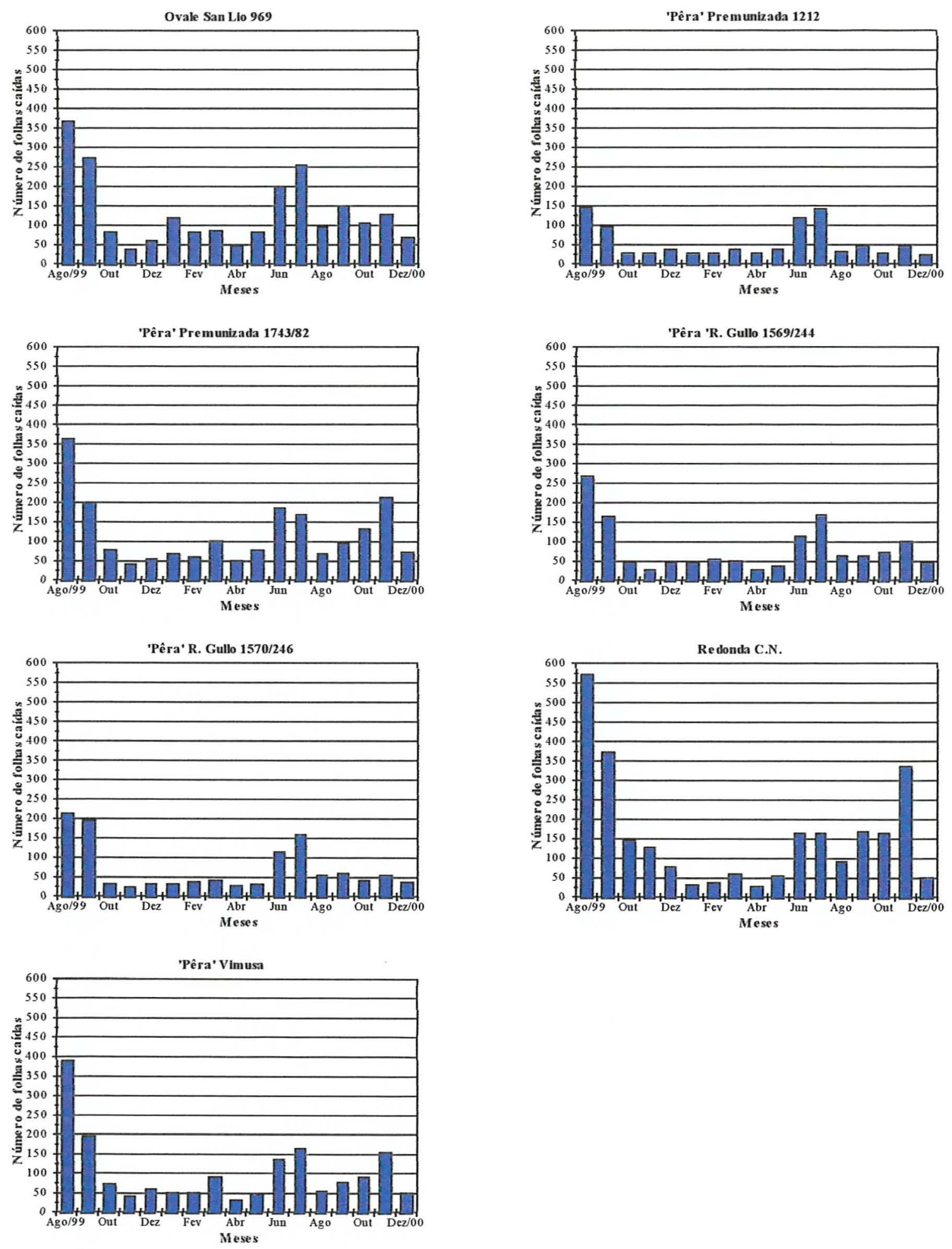


\section{REFERÊNCIAS BIBLIOGRÁFICAS}

AGRIOS, G.N. Plant pathology. 3 ed. New York. Academic Press, 1988. 803p.

AGUILAR-VILDOSO, C.I. Indução de pseudotécios de Guignardia citricarpa, em fragmentos foliares de diferentes espécies de plantas. Summa Phytopathologica, v. 22, n. 1, p.61, 1996.

AGUILAR-VILDOSO, C.I. Estrutura genética de Guignardia cirricarpa, agente causal da mancha preta dos citros, e resistência hospedeira no germoplasma de Cimus e afins. Piracicaba, 2001. 97p. Tese (Doutorado) - Escola Superior de Agricultura "Luiz de Queiroz", Universidade de São Paulo.

ALCOBA, N.J.; VIGIANI, A.R.; BEJARANO, N.V.; ALVAREZ, S.E.; SERRANO, M.A.; BONILLO, M.C. Mancha negra de los citricos. Epidemiologia y control. San Salvador de Jujuy: Ediciones Universidad Nacional de Jujuy, 2000. 56p.

ALLARD, R.W. Princípios do melhoramento genético das plantas. Rio de Janeiro: USAID, 1971. 381p.

AMARO, A.A.; MAIA, M.L. Produção e Comércio de laranja e de suco no Brasil. Laranja, v. 18, n. 1, p.1-26, 1997. 
AMORIM, L. Avaliação de doenças. In: BERGAMIN FILHO, A.; KIMATI, H.; AMORIM, L. (Ed.) Manual de fitopatologia. 3.ed. São Paulo: Agronômica Ceres, 1995. v.1: Princípios e Conceitos, cap.32, p.647-671.

AVERNA-SACCÁ, R. Pústulas pretas sobre laranjas doces produzidas pelo Phoma citricarpa. Revista de Agricultura, v.15, n.11/12, p.668-674, 1940.

BALDASSARI, R.B.; GOES, A. de; SANTOS, J.M. dos; TIMOSSI, A.J. Microscopia eletrônica de varredura de isolados de Guignardia citricarpa obtidos de plantas cítricas. Summa Phytopathologica, v.27, n.1, p.88-92, 2001.

BAUDOIN, A.B.A.M.; ECKERT, J.W. Development of resistance against Geotrichum candidum in lemon peel injuries. Phytopathology, v.75, p.174-179, 1985.

BONNAS, D.S.; CHITARRA, M.I.F.; CHITARRA, A.B.; MACHADO, J.C.; GAVILANES, M.L. Resistência pós-colheita de laranja 'Valência' ao Penicillium digitatum influenciada pela temperatura e tempo de cura de ferimento. Fitopatologia Brasileira, v.20, n.2, p. 169-173, 1995.

BROWN, G.E. Development of green mold in degreened oranges. Phytopathology, v.63, p.1104-1107, 1973.

BROWN, G.E.; BARMORE, C.R. Resistance of healed citrus exocarp to penetration by Penicillium digitatum. Phytopathology, v.73, p.691-694, 1983.

CAMPOS, S.B.; AGUILAR-VILDOSO, C.I. Efeito da glicose e sacarose no crescimento micelial de Guignardia citricarpa e Phytophthora parasitica. Summa Phytopathologica, v.27, n. 1, p.97, 2001.

CARROLL, G.C. Fungal endophytes in stems and leaves: from latent pathogen to mutualistic symbiont. Ecology, v.69, p.2-9, 1988. 
CLAY, K. Clavicipitaceous endophytes of grasses: their potential as biocontrol agents. Mycological Research, v.92, n.1, p.1-12, 1989.

CUNHA SOBRINHO, A.P; SOARES FILHO, W.S.; PASSOS, O.S. Melhoramento da laranja 'Pêra' Citrus sinensis (L.) Osbeck seleção de clones nucelares. In: CONGRESSO BRASILEIRO DE FRUTICULTURA, 5., Pelotas, 1979. Anais. Pelotas: Sociedade Brasileira de Fruticultura, 1979, p.602-608.

DI GIORGI, F.; IDE, B.Y.; DIB, K.; MARCHIN, R.J.; TRIBONI, H.R.; LOURO, R.W. Contribuição ao estudo do comportamento de algumas variedades de citros e suas implicações agro-industriais. Laranja, v.2, n.11, p.567-612, 1990.

DI GIORGI, F.; YASUHIRO IDE, B.; DIB, K.; MARCHI, R.J.; TRIBONI, H.R.; WAGNER, R.L. Proposta para ampliação do conceito de estimativa de safra quantitativa para qualitativa. Laranja, v.15, n.2, p.97-122, 1994.

DINIZ, E.F. Quantificação de componentes de resistência em variedades de feijão (Phaseolus vulgaris L.) a raças de Uromyces phaseoli var. typica Arth. Viçosa, 1988. 76p. Dissertação (Mestrado) - Universidade Federal de Viçosa.

DOMINGUES, E.T. Caracterização morfológica, agronômica, isoenzimática e por RAPD de variedades de laranja doce - Citrus sinensis (L.) Osbeck. Piracicaba, 1998. 251p. Tese (Doutorado) - Escola Superior de Agricultura "Luiz de Queiroz", Universidade de São Paulo.

DOMINGUES, E.T; MATTOS JÚNIOR, D.; TEÓFILO SOBRINHO, J.; POMPEU JÚNIOR, J.; FIGUEIREDO, J.O.; SUGAHARA, V.Y. Seleção de clones de laranja 'Pêra', quanto ao período de maturação, com uso da análise de agrupamento. Revista Brasileira de Fruticultura, v.19, n. 1, p.89-101, 1997. 
DOMINGUES, E.T.; TEÓFILO SOBRINHO, J.; POMPEU JÚNIOR, J; FIGUEIREDO, J.O; MATTOS JÚNIOR, D.; FINA, B.G. Caracterização do potencial agronômico das laranjeiras Redonda e Corsa Tardia. Revista Brasileira de Fruticultura, v.19, n.1, p.79-87, 1997a.

DONADIO, L.C.; FIGUEIREDO, J.O; PIO, R.M. Variedades cítricas brasileiras, Jaboticabal: FUNEP, 1995. 228p.

FAWCETT, H.S. Citrus disease and control. New York: McGraw Hill Book, 1936. $656 \mathrm{p}$.

FEICHTENBERGER, E. Mancha Preta dos Citros no Estado de São Paulo. Laranja, v.17, n.1, p.93-108, 1996.

FEICHTENBERGER, E.; MÜLLER, G.W.; GUIRADO, N. Doenças dos citros (Citrus spp). In: KIMATI, H.; AMORIM, L.; BERGAMIN FILHO, A.; CAMARGO, L.E.A.; REZENDE, J.A.M. (Ed.) Manual de fitopatologia. 3.ed. São Paulo: Agronômica Ceres, 1997. v.2: Doenças de plantas cultivadas, cap.25, p.261-296.

FIGUEIREDO, J.O. Comportamento da laranjeira 'Barão' Citrus sinensis (L.) Osbeck clone nucelar, em dez porta-enxertos. Campinas, 1976. 118p. Tese (Doutorado) Universidade Estadual de Campinas.

FIGUEIREDO, J.O. Variedades copa de valor comercial. In: RODRIGUEZ, O.; VIÉGAS, F.; POMPEU JÚNIOR, J.; AMARO, A.A. Citricultura brasileira. 2. ed. Campinas: Fundação Cargill, 1991. v.1, p.228-264.

FNP-CONSULTORIA \& COMÉRCIO. AGRIANUAL 2001: anuário da agricultura brasileira. São Paulo, 2001. 545p.

FUNDO PAULISTA DE DEFESA DA CITRICULTURA. Cancro avança. Revista do FUNDECITRUS, v.14, n.91, p.3, 1999. 
GAMA, G.B.M.N. DA; MEDEIROS, J.X. DE; PINHEIRO, L.E.L. O cenário da cooperação como fator de desenvolvimento para o sistema agroindustrial citros. Laranja, v.21, n.2, p. 239-258, 2000.

GLIENKKE, C. Variabilidade genética no fungo endófito Guignardia citricarpa Kiely detectada por RAPD. Curitiba, 1995. 115p. Dissertação (M.S.) - Universidade Federal do Paraná.

GOES, A. de. Controle da mancha preta dos frutos citricos. Laranja, v.19, n.2, p.305320,1998 .

GOES, A.de.; FEICHTENBERGER, E. Ocorrência da Mancha Preta causada por Phyllosticta citricarpa (Mc Alp) Van der Aa (Guignardia citricarpa Kiely) em pomares cítricos do Estado de São Paulo. Fitopatologia Brasileira, v.18 p.318, 1993.

GRAHAM, J.H.; TIMMER, L.W. Identification and control of Phytophthora species causing brown rot of citrus fruit. Citrus Industry. v.76, n.8, p. 38-40, 1995.

HASSE, G. A laranja no Brasil 1500-1987: a história da agroindústria cítrica brasileira, dos quintais coloniais às fábricas exportadoras de suco do século XX. São Paulo: Duprat \& Iobe Propaganda, 1987. 296p.

IGREJA, A.C.M.; NEVES, E.M.; BENETTON, M.E. Cadeia produtiva citricola: transmissão de tendências alocativas da indústria para o elo agrícola. Laranja, v.21, n. 2, p. $239-258,2000$.

INSTITUTO DE ECONOMIA AGRÍCOLA. Os números da citricultura. São Paulo: Secretaria da Agricultura e Abastecimento, 1997. 28p.

INTERNATIONAL PLANT GENETIC RESOURCES INSTITUTE. Descriptiors for citrus. Rome, 1999. 66p. 
KATSURAYAMA, Y.; MAFFIA, L.A.; ALVAREZV, V.H.; VALE, F.X.R. Tamanho da parcela e número de repetições para quantificação dos componentes de resistência do feijoeiro à ferrugem. Fitopatologia Brasileira, v.18, p.62-69, 1993.

KELLERMAN, C.R.; KOTZÉ, J.M. The black spot disease of citrus and its control in South Africa. Proceedings International Society Citriculture, v.3, p.992-996, 1977.

KIELY, T.B. Preliminary studies on Guignardia citricarpa N. SP. The ascigerous stage of Phoma citricarpa McAlp. and its relation to black spot of citrus. Proceedings of the Linnean Society of New South Wales. v.73, p.249-292, 1948.

KLOTZ, L.J. Color handbook of citrus diseases. Riverside: Citrus Res. Center and Agric. Exp. Station, 1973. 122p.

KLOTZ, L.J. Fungal, bacterial, and nonparasitic diseases and injuries originating in the seebed, nursery, and orchard. In: REUTHER, W.; CALAVAN, E. C.; CRMAN, G. E. (Ed.) The citrus industry. Riverside: University of California, 1978. p.1-66.

KOTZÉ, J.M. Studies on the black spot disease of citrus caused by Guignardia citricarpa Kiely, with particular reference to its epiphytology and control at Labata. Pretoria, 1963. 143p. Tese (Doutorado) - University of Pretoria.

KOTZÉ, J.M. Epidemiology and control of citrus black spot in South Africa. Plant Disease, v.65, n.12, p.945-950, 1981.

KOTZÉ, J.M. Fungal diseases in nurseries and orchards: black spot. In: WHITESIDE, J.O.; GARNSEY, S.M.; TIMMER, L.W. Compendium of citrus diseases. St. Paul: APS Press, 1988. p.10-12.

McONIE, K.C. Source of inoculum of Guignardia citricarpa, the citrus black spot pathogen. Phytopathology, v.54, n. 12, p.64-67, 1964a. 
McONIE, K.C. Orchard development and discharge of ascospores of Guigzardia citricarpa and the onset of infection in relation to the control of citrus black spot. Phytopathology, v.54, n.12, p.1448-1453, 1964b.

McONIE, K.C. Germination and infection of citrus by ascospores os Guignardia citricarpa in relation to control of black spot. Phytopathology, v.57, p.743-746, 1967.

MOURÃO FILHO, F.A.A.; MISCHAN, M.M.; SALIBE, A.A. Efeito de diferentes porta-enxertos no vigor e na produtividade da laranjeira 'Pêra' (Citrus sinensis L.) Osbeck). Anais da Escola Superior de Agricultura "Luiz de Quieroz", Piracicaba, v.48, p.167-184, 1991.

MULLER, G.W.; COSTA, A.A.; TEÓFILO SOBRINHO, J. Experimentos para estudar possivel efeito de estirpes fracas do vírus da tristeza em copas de laranjas doces consideradas tolerantes. In: CONGRESSO BRASILEIRO DE FRUTICULTURA, 3. , Campinas, 1975. Anais. Campinas: Sociedade Brasileira de Fruticultura, 1975. p.181-185.

NEVES, E.M.; NEVES, M.F. Suco concentrado de laranja. Uma commodity sui generis. Preços Agrícolas, v.10, n.114, p.11-13, 1996.

PASCHOLATI, S.F.; LEITE, B. Mecanismos bioquímicos de resistência a doenças. Revisão Anual de Patologia de Plantas, v.2, p.1-51, 1994.

PASCHOLATI, S.F.; LEITE, B. Hospedeiro: mecanismos de resistência. In: BERGAMIN FILHO, A.; KIMATI, H.; AMORIM, L. (Ed.) Manual de fitopatologia. 3.ed. São Paulo: Agronômica Ceres, 1995. v.1: Princípios e Conceitos. cap. 22, p. $417-453$. 
PASSOS, O.S.; CUNHA SOBRINHO, A.P. Estudo comparativo entre clone nucelar e clone velho de laranja 'Pêra' ( $C$. sinensis L. Osbeck). In: CONGRESSO BRASILEIRO DE FRUTICULTURA, 1., Campinas, 1971. Anais. Campinas: Sociedade Brasileira de Fruticultura, 1971. p.277-288.

PRABHU, A.S.; MORAIS, O.P. Resistência estável às doenças de plantas. Revisão Anual de Patologia de Plantas, v.1, p.239-273, 1993.

PUNITHALINGAM, E; WOODHAMS, J.E. The conidial appendage in Phyllosticta spp. Nova Hedwigia, v.36, p.151-175, 1982.

RESENDE, M.L.V. Mecanismos de resistência de plantas a doenças fúngicas vasculares. Revisão Anual de Patologia de Plantas, v.4, p.329-351, 1996.

ROBBS, C.F.; BITTENCOURT, A.M. A mancha preta dos frutos um dos fatores limitantes à produção citrícola do Estado do Rio de Janeiro. Comunicado Técnico (Embrapa), n. 19, p. 1-5, 1995.

ROBBS, C.F. A mancha preta dos frutos cítricos (Phyllosicta citricarpa) ameaça a citricultura paulista. Laranja, v.11, n. 1, p.87-95, 1990.

ROBBS, C.F.; PIMENTEL, J.P.; RIBEIRO, R.L.D. A mancha preta dos frutos cítricos causada por Phoma citricarpa. Fitopatologia Brasileira, v.5, n.3, p.455, 1980.

ROBBS, C.F.; PIMENTEL, J.P.; RIBEIRO, R.L.D. A mancha preta dos citros: identificação da forma perfeita Guignardia citricarpa no Estado do Rio de Janeiro. Fitopatologia Brasileira, v. 10, n.2, p.248, 1985.

RODRIGUEZ, O. Ecofisiologia dos citros. In: CASTRO, P.R.C.; FERRERA, S.O; YAMADA, T. (Ed.) Ecofisiologia da produção agrícola. Piracicaba: Associação Brasileira para Pesquisa da Potassa e do Fosfato. 1987. p.149-164.

ROSSETTI, V; MULleR, G.W; COSTA, A.S. Doenças dos citros causadas por algas, fungos, bactérias e vírus. Campinas: Fundação Cargill, 1993. 84p. 
ROSSETTI, V.; FEICHTENBERGER, E.; MUNTANER, A.I.C.; LEITE, Y.; TEÓFILO SOBRINHO, J. POMPEU JÚNIOR, J. Comportamento de 13 seleções de laranja 'Pêra' com diferentes variantes de tristeza, com relação à Gomose de Phytophthora. In: CONGRESSO BRASILEIRO DE FRUTICULTURA, 3., Rio de Janeiro, 1975. Anais. Rio de Janeiro; Sociedade Brasileira de Fruticultura, 1975. p.147-154.

SALIBE, A.A., Os segredos da alta produtividade. Laranja \& Cia, n.43, p.6-9, 1996.

SAMPAIO, V.R.; BARBIN, D. Influência da borbulha de clones velhos e nucelares na muda de Citrus. Anais da Escola Superior de Agricultura "Luiz de Queiroz". v. 35, p. $457-469,1978$.

SIEGEL, M.R.; LACTH, G.C.M.; JOHNSON, M.C. Fungal endophytes of grasses. Annual Review of Phytopathology, v.25, p.293-315, 1987.

SILVA, A.S.; AGULLAR-VILDOSO, C.I. Efeito in vitro do tipo de folha cítrica na produção de corpos de frutificação de Guignardia citricarpa. Summa Phytopathologica, v.26, n. 1, p.99, 2000.

SIVANESAN, A. The bitunicate ascomycetes and their anamorphs Berlin: J Cramer, 1984. $701 \mathrm{p}$.

SPÓSITO, M.B.; BASSANEZI, R.B.; FARIAS, P.R.; LOURENÇO, S.A.; LARANJEIRA, F.F.; AMORIM, L.; BERGAMIN FILHO, A. Spatial pattern of citrus black spot in Brazil. In: INTERNATIONAL WORKSHOP ON PLANT DISEASE EPIDEMIOLOGY, 8., Ouro Preto, 2001. Anais. p.6-11.

STEEL, R.G.D.; TORRIE, J.H. Principles and procedures of statistics. New York. McGraw-Hill, 1980. 633p. 
TEÓFILO SOBRINHO, J.; POMPEU JÚNIOR, $J$; FIGUEIREDO, J.O; BARBIN, D; DEMÉTRIO, C.G.B. Competição de onze porta enxertos para laranja 'Pêra' Citrus sinensis (L.) Osbeck. In: CONGRESSO BRASILEIRO DE FRUTICULTURA, 7., Florianópolis, 1984. Anais. Florianópolis: Sociedade Brasileira de Fruticultura, 1984. p.581-591.

TEÓFILO SOBRINHO, J; POMPEU JÚNIOR, J; FIGUEIREDO, J.O; DEMÉTRIO, C.G.B.; BARBIN, D. Competição entre quinze clones de laranjeira 'Pêra' na região de Limeira. Revista Brasileira de Fruticultura, v.14, n.1, p.41-48, 1992.

TEÓFILO SOBRINHO, J.; POMPEU JÚNIOR, J.; FIGUEIREDO, J.O.; DOMINGUES, E.T.; TANNURI, F. Seleção de clones de laranjeira 'Pêra' em Araraquara (SP). Revista Brasileira de Fruticultura, v.18, n.2, p.275-282, 1996.

TEÓFILO SOBRINHO, J.; POMPEU JUNIOR, J.; RODRIGUEZ, O; FIGUEIREDO, J.O; BARBIN, D. Melhoramento de clones de laranjeira 'Pêra' no Estado de São Paulo. In: CONGRESSO BRASILEIRO DE FRUTICULTURA, 4., Salvador, 1977. Anais. Salvador: Sociedade Brasileira de Fruticultura, 1977 p.111-116.

TEÓFILO SOBRINHO, J; ; POMPEU JÚNIOR, J;; RODRIGUEZ, O; FIGUEIREDO, J.O; BARBIN, D. Competição de clones de laranja 'Pêra' (Citrus sinensis L. Osbeck). In: CONGRESSO BRASILEIRO DE FRUTICULTURA, 6., Recife, 1981. Anais. Recife: Sociedade Brasileira de Fruticultura, 1981. p.491-500.

TEÓFILO SOBRINHO, J.; POMPEU JÚNIOR, J; FIGUEIREDO, J.O; DEMÉTRIO, C.G.B.; BARBIN, D.; TANNURI, F. Competição entre clones de laranja 'Pêra', enxertada sobre limão 'Cravo' na região de Araraquara (SP). In: CONGRESSO BRASILEIRO DE FRUTICULTURA, 10, Fortaleza, 1989. Anais. Fortaleza: Sociedade Brasileira de Fruticultura, 1989. p.86-91. 
TEÓFILO SOBRINHO, J.; SALIBE, A.A.; POMPEU JÚNIOR, J.; FIGUEIREDO, J.O; GUIRADO, N.; BARBIN, D. Competição de treze clones de laranja 'Pêra' enxertados sobre limão 'Cravo'. Resultados de 14 anos de produção. In: CONGRESSO BRASILEIRO DE FRUTICULTURA, 9., Campinas, 1987. Anais. Campinas: Sociedade Brasileira de Fruticultura, 1987. p.249-255.

TSAI, Y.P. Citrus black spot control in Taiwan. Proceedings International Society Citriculture, v.1, p.344-346, 1981.

TUBELIS, A.; TEÓFILO SOBRINHO, J.; SALIBE, A.A. Análise da produção de laranja 'Pêra Bianchi' em função da idade da planta e de precipitações pluviais. Pesquisa Agropecuária Brasileira, v.27, n.5, p.671-676, 1992.

VANDERPLANK, J.E. Plant diseases: epidemics and control. New York. Academic Press. 1963. 349p.

VIÉGAS, F.C.P. A industrialização dos produtos citricos. In: RODRIGUEZ, O; VIÉGAS, F; POMPEU JÚNIOR, $J$; AMARO, A. A. Citricultura brasileira 2 . ed. Campinas: Fundação Cargill, 1991. v.2, p.898-921. 